Fernando Brisola de Almeida Bueno

\title{
TRATAMENTO DE ÁGUA PARA ABASTECIMENTO CONTENDO CIANOBACTÉRIAS E MICROCISTINA EM SISTEMA CONSTITUÍDO POR ETAPAS DE PRÉ- CLORAÇÃO, COAGULAÇÃO/FLOCULAÇÃO, FLOTAÇÃO E ADSORÇÃO EM CARVÃO ATIVADO
}

Dissertação apresentada à
Escola de Engenharia de São
Carlos, Universidade de São
Paulo, como parte dos requisitos
para obtenção do Título de
mestre em Hidráulica e
Saneamento.

ORIENTADOR: Prof ํ. Dr. Marco Antonio Penalva Reali 
Ficha catalográfica preparada pela Seção de Tratamento da Informação do Serviço de Biblioteca - EESC/USP

B928t

Bueno, Fernando Brisola de Almeida

Tratamento de água para abastecimento contendo cianobactérias e microcistina em sistema constituído por etapas de pré-cloração, coagulação/floculação, flotação e adsorção em carvão ativado / Fernando Brisola de Almeida Bueno. -- São Carlos, 2005.

Dissertação (Mestrado) -- Escola de Engenharia de São Carlos-Universidade de São Paulo, 2005.

Área: Hidráulica e Saneamento.

Orientador: Prof. Dr. Marco Antonio Penalva Reali.

1. Cianobactérias. 2. Microcistina. 3. Pré-oxidação. 4. Flotação. 5. Carvão ativado. I. Título. 
FOLHA DE JULGAMENTO

Candidato: Engenheiro FERNANDO BRISOLA DE ALMEIDA BUENO

Dissertação defendida e julgada em 13-05-2005 perante a Comissão Julgadora:

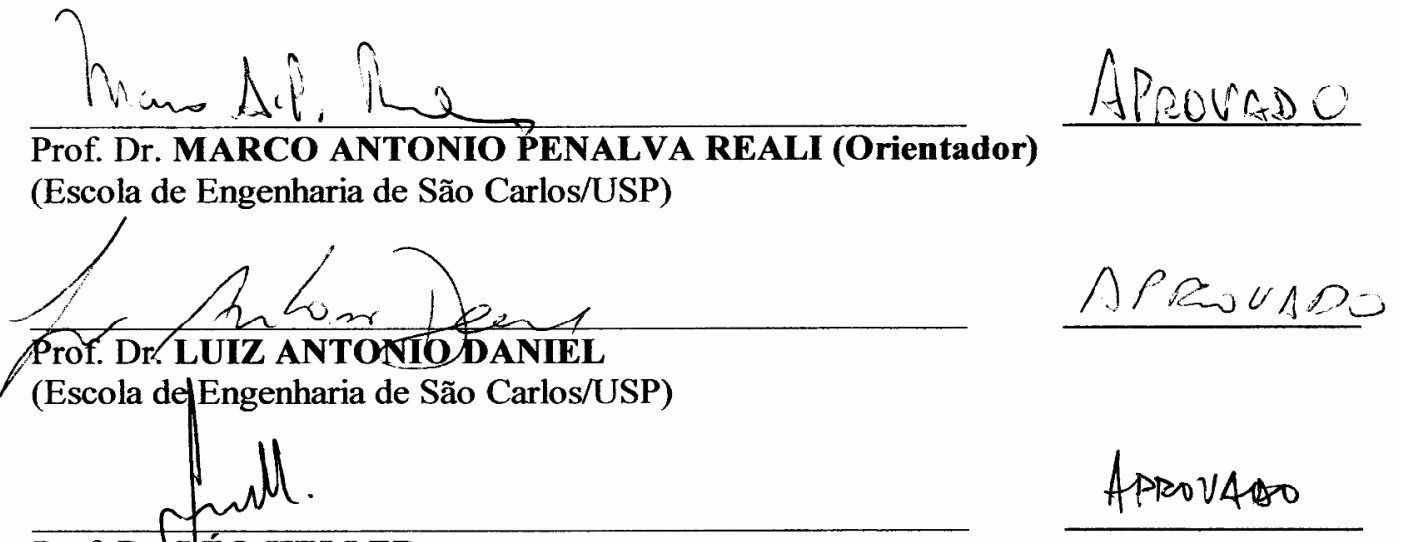

Prof. Dr.ILÉO HELLER

(Universidade Federal de Minas Gerais/UFMG)

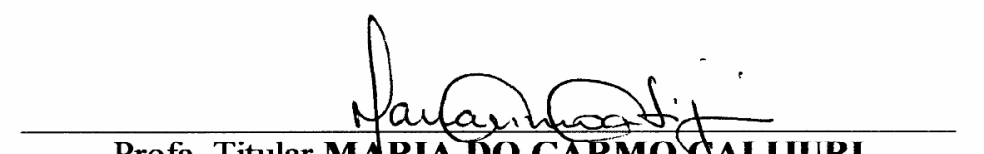

Profa. Titular MARIA DO CARMO GALIJURI

Coordenadora do Programa de Pós-Graduação em

Engenharia (Hidráulica e Saneamento) e

Presidente da Comissão de Pós-Graduação 
Dedico esse trabalho ao meu avô, Antônio de Almeida Bueno, a figura paterna que sempre me guiou e inspirou; à minha mãe, Marina Brisola que, se preocupando comigo até mais do que eu mesmo, sempre esteve ao meu lado em todas minhas decisões, erros e acertos; e à minha namorada Cristiane Maleski Belini por nesses três anos e meio ter sido minha amiga e companheira que mesmo longe, no momento, me ama, me apóia e me trás confiança. 


\section{Agradecimentos}

Agradeço ao meu professor orientador, Prof. Dr. Marco Antonio Penalva Reali, pelo incentivo a fazer o mestrado desde o começo de minha iniciação científica e pela competente orientação ao longo desses anos.

Aos professores do departamento, principalmente à $\operatorname{Prof}^{a} \operatorname{Dr}^{a}$ Maria do Carmo Calijuri, ao Prof. Dr. José Roberto Campos e ao Prof. Dr. Luiz Antonio Daniel, pelo apoio, pela ajuda, pelas dicas e conselhos, além da tentativa de criar em nós, alunos, espírito crítico e coragem para trilharmos os árduos caminhos fora da universidade.

À Profa $\mathrm{Dr}^{\mathrm{a}}$ Ruth Gouvêa Duarte pelos valorosos conselhos profissionais e pessoais, pela amizade, pelos jantares, petiscos, além, é claro, pelas correções voluntárias de todos trabalhos, seminários, exames de qualificação e desta dissertação.

À equipe de trabalho Leila Jorge Patrizzi, Rodrigo Braga Moruzzi, Luciana Pallone Hespanholo Ferreira, Maurício Fernandes Perez, Tatiana Porto, André Luiz Oliveira e à André Luiz Vieira da Silva com quem dividi o laboratório durante todos os ensaios.

Aos técnicos dos laboratórios pertencentes ao departamento Julio, Paulo, Ana Paula, Wagner, Luci, Janja e Prof ${ }^{a}$ Bete que nunca se negaram a ajudar, acompanhar e ensinar.

Ao Prof. Evaldo Luiz G. Espíndola e sua orientanda Luci, por terem cedidos espaço e pelo auxílio com a cultura de cianobactérias e ao Prof ${ }^{\circ}$. Dr. Armando Augusto $\mathrm{H}$. Vieira por fornecer a cepa com que começamos a cultura de cianobactérias.

Ao CNPq pela bolsa de estudo, à FAPESP pelo financiamento da pesquisa e à Escola de Engenharia de São Carlos pela sólida formação tanto na graduação quanto na pós.

Aos funcionários do Departamento de Hidráulica e Saneamento, Sá, Pavi, Rose, Fábio, Flávia e Alessandra. 
Aos amigos do departamento com quem compartilhei disciplinas, rodas de conversas, reclamações, prazos e tudo aquilo que envolve um curso de pósgraduação.

À todos moradores e ex-moradores da República Romeu \& Julieta com quem vivi sete anos da minha vida morando, conversando, bebendo, comendo, viajando, rindo, brigando e, principalmente, construindo uma amizade eterna.

À toda minha família Brisolas e Almeidas que, seja de São Miguel Arcanjo ou de Itapetininga, tenho certeza, torceram sempre pelo meu sucesso.

À minha outra família, os meus amigos, pela amizade sincera ao longo de todos esses anos, hoje cada um em uma cidade e em um emprego, mas dispostos a se deslocarem a distância que for para nos reencontramos sempre em alguma ocasião pensada e planejada para todos estarem presentes.

Ao Sport Club CORINTHIANS Paulista por todas alegrias e emoções ao longo de toda minha vida. 
"Enquanto o poço não seca não sabemos dar valor à água" "We never know the worth of water till the well is dry"

Thomas Fuller - clérigo e historiador (1610 - 1661) 


\section{RESUMO}

BUENO, F. B. A. (2005). Tratamento de Água Para Abastecimento Contendo Cianobactérias e Microcistina em Sistema Constituído por Etapas de PréCloração, Coagulação/Floculação, Flotação e Adsorção em Carvão Ativado. Dissertação (Mestrado) - Escola de Engenharia de São Carlos. Universidade de São Paulo, São Carlos.

A captação de água para abastecimento público, a cada dia, torna-se mais problemática devido ao grande número de mananciais eutrofizados. A eutrofização causa grande preocupação, pois é comum o surgimento de florações com presença de organismos fitoplanctônicos potenciais produtores de toxinas nocivas à saúde. Entre essas toxinas a grande contaminadora é a microcistina produzida por cianobactérias - tóxico potente que causa sérios agravos à saúde e pode levar à morte. Este trabalho de pesquisa testou alguns processos de tratamento de água - pré-oxidação, coagulação/floculação, flotação por ar dissolvido e adsorção em carvão ativado - com o propósito de verificar quão eficientes eles seriam na remoção dessa toxina. Em escala de laboratório foram realizados ensaios de coagulação/floculação, seguidos de flotação sem adição e com adição de préoxidante e carvão ativado em pó. Para a água de estudo verificou-se que o baixo $\mathrm{pH}$ é fator positivo para o tratamento. A pré-oxidação aplicada ao tratamento apresentou bons resultados na remoção de microcistina; o tempo de contato do oxidante também exerceu influência na qualidade. A associação de pré-oxidação e adsorção em carvão ativado elevou a eficiência de remoção de toxina. Embora os sistemas convencionais de tratamento de água não sejam eficientes na remoção de microcistina a flotação é melhor que a sedimentação.

Palavras-chave: cianobactérias; microcistina; pré-oxidação; flotação; carvão ativado 


\section{ABSTRACT}

BUENO, F. B. A. (2005). Drinking-Water Treatment with Cyanobacteria and Microcistin in a System Composed by Stages of Preoxidation, Coagulation/Flocculation, Flotation and Adsorption on Activated Carbon. M.Sc Dissertation - Escola de Engenharia de São Carlos. Universidade de São Paulo, São Carlos.

At each day, the captivation of water for public supplying is becoming more difficult because of the emerging blooming with the presence of phitoplanktonic organisms which in turn are potential producer of harmful toxins to the health. Among those toxins the major contaminant is the microcistin produced by cyanobacteria - a powerful toxin that causes serious hazards to the health being able also to cause death. In this work the investigation had tested some water treatment processes preoxidation, coagulation/flocculation, dissolved air flotation and adsorption on activated carbon - with the purpose to check how efficient they would be to remove that toxin. In the laboratory assays, coagulation/flocculation followed by flotation were performed with and without addition of preoxidant and activated carbon powder. In this study, the $\mathrm{pH}$ demonstrated to be a positive factor for the treatment. The preoxidation applied to the treatment presented good results in the microcistina removing; the oxidant contact time also played influence in the quality; the association of preoxidant and adsorption on activated carbon just raised the toxin remotion efficiency. Although the conventional water treatment systems are not efficient in the microcistina removal, the flotation is better than sedimentation.

Keywords: cyanobacteria; microcistin; preoxidation; flotation; activated carbon 


\section{LISTA DE FIGURAS}

Figura 3.1 - Exemplos de cianobactérias (a) Anabaena, (b) Microcystis,(c) Oscilattoria e (d) Chroococcus.

Figura 3.2 - Fotos com exemplos de florações em um lago (à esquerda) e em um rio (à direita).

Figura 3.3 - Estrutura química da molécula de microcistina-LR

Figura 3.4 - Curva de cloro residual em relação à dosagem de cloro adicionada

Figura 3.5 - Ângulo de contato entre uma fase sólida e uma fase gasosa imersa numa fase líquida.

Figura 3.6 - Dois exemplos de estrutura química do grafite.

Figura 3.7 - Representação esquemática de um grânulo de carvão ativado.

Figura 3.8 - Estrutura molecular do azul de metileno.

Figura 4.1 - Esquema simplificado dos ensaios

Figura 4.2 - Esquema localizando o reservatório de Barra Bonita no interior do Estado de São Paulo.

Figura 4.3 - Fotos do ponto de coleta no reservatório de Barra Bonita.

Figura 4.4 - Detalhamento dos Ensaios da Primeira Etapa do Estudo

Figura 4.5 - Detalhamento dos ensaios da Segunda Etapa

Figura 4.6 - Isotermas de Freundlich e Langmuir obtidas para o carvão 3.

Figura 4.7 - Detalhamento dos ensaios da Terceira Etapa 
Figura 4.9 - Esquema ilustrativo do Flotateste.

Figura 4.10 - Placa para determinação que integra o Kit

Figura 4.11 - Esquema ilustrativo do método de determinação de microcistina

Figura 5.1 - Curvas de Cor aparente residual para cada dosagem de coagulante com variação do $\mathrm{pH}$ de coagulação, para amostras coletadas na velocidade $1(\mathrm{v}=15,6 \mathrm{~m} / \mathrm{h})$.

Figura 5.2 - Diagrama de coagulação, visando flotação, construído a partir da figura 5.1 delimitando as regiões de eficiência de remoção de cor aparente para a velocidade 1 .

Figura 5.3 - Curva de Cor aparente residual para cada dosagem de coagulante com variação do $\mathrm{pH}$ de coagulação, para amostras coletadas na velocidade $2(\mathrm{v}=7,8 \mathrm{~m} / \mathrm{h})$.

Figura 5.4 - Diagrama de coagulação, visando flotação, construído a partir da figura 5.3 delimitando as regiões de eficiência de remoção de cor aparente para a velocidade 2 .

Figura 5.5 - Curvas de Turbidez residual para cada dosagem de coagulante com variação do $\mathrm{pH}$ de coagulação, para amostras coletadas na velocidade $1(\mathrm{v}=15,6 \mathrm{~m} / \mathrm{h})$.

Figura 5.6 - Diagrama de coagulação, visando flotação, construído a partir da figura 5.5 delimitando as regiões de eficiência de remoção de turbidez para a velocidade 1.

Figura 5.7 - Curva de Turbidez residual para cada dosagem de coagulante com variação do $\mathrm{pH}$ de coagulação, para amostras coletadas na velocidade $2(\mathrm{v}=7,8 \mathrm{~m} / \mathrm{h})$.

Figura 5.8 - Diagrama de coagulação, visando flotação, construído a partir da figura 5.7 delimitando as regiões de eficiência de remoção de turbidez para a velocidade 2.

Figura 5.9 - Cloro residual em relação à dosagem de hipoclorito de sódio para a água de estudo.

Figura 5.10 - Resultados de cor aparente em ensaios de flotação precedidos de pré-oxidação com dosagem de oxidante $(\mathrm{NaOCl})$ de $2,1 \mathrm{mg} / \mathrm{L}$.

Figura 5.11 - Resultados de turbidez em ensaios de flotação precedidos de préoxidação com dosagem de oxidante $(\mathrm{NaOCl})$ de $2,1 \mathrm{mg} / \mathrm{L}$. 
Figura 5.12 - Resultados de cor aparente em ensaios de flotação precedidos de pré-oxidação com dosagem de oxidante $(\mathrm{NaOCl})$ de $6,0 \mathrm{mg} / \mathrm{L}$

Figura 5.13 - Resultados de turbidez em ensaios de flotação precedidos de préoxidação com dosagem de oxidante $(\mathrm{NaOCl})$ de $6,0 \mathrm{mg} / \mathrm{L}$.

Figura 5.14 - Contagem de organismos fitoplanctônicos da cultura preparada em laboratório, da água do reservatório e da água de estudo 2.

Figura 5.15 - Concentração de microcistina para ensaio de oxidação da água de estudo com tempo de contato do oxidante de 30 minutos.

Figura 5.16 - Concentração de trihalometanos em relação à dosagem de hipoclorito de sódio e ao tempo de contato do oxidante

Figura 5.17 - Concentrações residuais de clorofila-a, microcistina e clorofórmio para dosagem de coagulante e oxidante indicadas com aplicação do oxidante $10 \mathrm{~s}$ antes da coagulação.

Figura 5.18 - Concentrações residuais de clorofila-a, microcistina e clorofórmio para as duas dosagens de oxidante estudadas e dosagem de coagulante de $50 \mathrm{mg} / \mathrm{L}$ (aplicação do oxidante 10 segundos antes da coagulação).

Figura 5.19 - Concentrações residuais de clorofila-a, microcistina e clorofórmio para dosagem de coagulante e oxidante indicadas com aplicação do oxidante 90 min antes da coagulação.

Figura 5.20 - Comparação dos resultados obtidos para microcistina somente com a pré-oxidação e para a associação de pré-oxidação e adição de CAP para o par de valores dosagem de coagulante e oxidante (aplicação de $\mathrm{NaOCl} 10 \mathrm{~s}$ antes da coagulação)

Figura 5.21 - Concentrações residuais de clorofila-a, microcistina e clorofórmio para as duas dosagens de oxidante estudadas e dosagem de coagulante de $50 \mathrm{mg} / \mathrm{L}$ (aplicação do oxidante 90 minutos antes da coagulação).

Figura 5.22 - Esquema mostrando todas as situações estudadas com seus melhores resultados obtidos. 


\section{LISTA DE TABELAS}

Tabela 3.1 - Remoção de turbidez e clorofila com variação de dosagem de coagulante.

Tabela 4.1 - Descrição do meio de cultura ASM-1

Tabela 4.2 - Caracterização dos carvões testados em relação ao número de iodo e número de azul de metileno.

Tabela 5.1 - Caracterização da cultura, da água do reservatório e da água de estudo 1.

Tabela 5.2 - Caracterização da água de estudo 2

Tabela 5.3 - Ensaios simplificados de tratabilidade por coagulação/floculação seguidos de flotação com resultados de cor aparente e turbidez para a água de estudo 2.

Tabela 5.4 - Caracterização da água após flotação com dosagem de coagulante 45 $\mathrm{mg} / \mathrm{L}$.

Tabela 5.5 - Concentração de trihalometanos total $(\mu \mathrm{g} / \mathrm{L})$ em função da dosagem de hipoclorito de sódio e do tempo de contato.

Tabela 5.6 - Ensaio de de pré-oxidação, coagulação/floculação seguidos de flotação com resultados de cor aparente, turbidez e absorbância 264 $\mathrm{nm}$, com adição de pré-oxidante 10 segundos antes da coagulação, para a água de estudo 2 .

Tabela 5.7 - Caracterização das amostras após ensaio de flotação com préoxidação10 segundos antes da coagulação $\left(\mathrm{V}_{\text {flot }}=13 \mathrm{~cm} / \mathrm{min}\right)$.

Tabela 5.8 - Caracterização das amostras após ensaio de flotação com préoxidação 90 minutos antes da coagulação.

Tabela 5.9 - Caracterização das amostras após ensaio de flotação com préoxidação 10 segundos antes da coagulação e adição de CAP.

Tabela 5.10 - Comparação entre os resultados de pré-oxidação com $10 \mathrm{~s}$ de contato, coagulação/floculação e flotação por ar dissolvido sem e com a adição de carvão ativado em pó.

Tabela 5.11 - Caracterização das amostras após ensaio de flotação com préoxidação 90 minutos antes da coagulação e adição de CAP. 
1 - INTRODUÇÃO E JUSTIFICATIVA

2 - OBJETIVOS 5

3 - REVISAO BIBLIOGRÁFICA 6

3.1 - Eutrofização 6

3.2 - Florações, Cianobactérias e suas Toxinas 8

3.2.1 - Características das Cianobactérias 8

$\begin{array}{ll}3.2 .2 \text { - Florações } & 11\end{array}$

3.2.3 - Microcistina $\quad 12$

3.3 - Problemas Atribuídos à Algas e Cianobactérias em Estações de Tratamento de Água 16

3.4 - Oxidação 19

3.4.1 - Cloração no Breakpoint 22

3.4.2 - Formação de Trihalometanos 23

3.5 - Coagulação/Floculação 24

3.6 - Flotação por Ar Dissolvido 26

$\begin{array}{ll}3.7 \text { - Carvão Ativado } & 37\end{array}$

4 - MATERIAIS E MÉTODOS 41

4.1 - Considerações Iniciais $\quad 41$

4.2 - Água de Estudo $\quad 42$

4.2.1 - Características do Local de Coleta 42

4.2.2 - Coleta e Preparo da Água de Estudo 44

4.2.3 - Cultura de Cianobactérias $\quad 46$

4.2.4 - Caracterização das Águas de Estudo 48

4.3 - Procedimento Adotados nos Ensaios $\quad 50$

4.3.1 - Primeira Etapa 51

4.3.2 - Segunda Etapa $\quad 54$ 
4.3.3 - Terceira Etapa

4.4 - Equipamento Utilizados nos Ensaios

4.4.1 - Jarteste

4.4.2 - Flotateste

4.5 - Descrição dos Empregados na Pesquisa para

Determinação de Clorofila-a, Trihalometanos e Microcistina

4.5.1 - Método de Determinação de Clorofila-a

4.5.2 - Método de Determinação de Trihalometanos

4.5.3 - Método de Determinação de Microcistina

5 - RESULTADOS E DISCUSSÕES

5.1 - Considerações Iniciais

5.2 - Resultados da Primeira Etapa 70

5.2.1 - Primeira Fase da Primeira Etapa

5.2.2 - Segunda Fase da Primeira Etapa

5.3 - Resultados da Segunda Etapa

5.3.1 - Primeira Fase da Segunda Etapa

5.3.2 - Segunda Fase da Segunda Etapa

5.3.3 - Terceira Fase da Segunda Etapa

5.3.4 - Quarta Fase da Segunda Etapa

5.4 - Resultados da Terceira Etapa

5.4.1 - Primeira Fase da Terceira Etapa

5.4.2 - Segunda Fase da Terceira Etapa

5.5 - Resumo dos Resultados

6 - CONCLUSÕES 


\section{1 - INTRODUÇÃO E JUSTIFICATIVA}

"A água é fonte primordial da vida" Hieróglifos egípcios datados do $3^{\circ}$ milênio a.C.

Os dados do censo de 1980 e a projeção para o ano de 2010 indicam um crescimento populacional de $66 \%$ no Brasil. Esse crescimento da população, que se caracteriza como uma explosão demográfica, per se já requer enorme aumento de água disponível. O constante aprimoramento da tecnologia e a expansão industrial levam a um assustador consumo de água. Conseqüentemente também aumentaram rapidamente os descartes de efluentes doméstico e industrial.

Esses efluentes contêm enorme variedade de substâncias; entre elas os micronutrientes e macronutrientes, responsáveis pelo fenômeno de eutrofização da água de lagos e reservatórios, destacando-se o nitrogênio e o fósforo, nas suas variadas formas, os quais no manancial transformam-se em nitrato e em fosfato, respectivamente, formas nos quais são consumidos por macrófitas, cianobactérias e outros organismos fitoplanctônicos. Além desses despejos existem outras formas de entrada de nutrientes nos corpos de água como o carreamento de fertilizantes pela água da chuva e erosão do solo. 
A eutrofização da água é um dos mais graves problemas do saneamento, que preocupa os sanitaristas quanto à contaminação da água captada para abastecimento que poderia causar problemas à saúde dos usuários.

Um dos resultados da eutrofização é o crescimento de microrganismos no meio aquático. As florações de algas são resultado imediato do enriquecimento por nutrientes; nelas é comum encontrarem-se cianobactérias. Quanto mais freqüentes as florações e maiores em volume, maiores as chances estatísticas da presença de cianobactérias.

Muitas espécies de cianobactérias apresentam como característica a produção de cianotoxinas; das cianotoxinas a que foi primeira detectada e a mais conhecida é a microcistina. As cianotoxinas são produzidas pelas células de cianobactérias como metabólitos secundários; entre os organismos que produzem microcistinas estão os dos gêneros Microcystis e Anabaena. A espécie Microcystis aeruginosa apresenta a mais ampla distribuição no Brasil e Anabaena é o gênero com o maior número de espécies potencialmente tóxicas.

A microcistina geralmente está presente nas células, mas com a lise celular elas são liberadas nas águas. A literatura reporta acidentes sérios com humanos ocorridos devido à presença de microcistinas na água. Por exemplo, alta incidência de câncer no fígado de indivíduos de uma comunidade da China cuja causa tem sido atribuída ao consumo de água contaminada por microcistinas (ISHII et al., 2004).

Tendo em vista os riscos associados à presença de cianotoxinas nas águas dos mananciais destinados ao abastecimento publico o Ministério da Saúde do governo brasileiro publicou em 25 de março de 2004 a Portaria número 528 na 
qual estabelece como concentração máxima admissível de microcistina na água potável $1 \mu \mathrm{g} / \mathrm{L}$.

No Brasil a água para consumo humano é captada principalmente de mananciais de superfície como rios e reservatórios. A presença de cianobactérias e outros organismos fitoplanctônicos pode provocar diversos problemas nas estações convencionais de tratamento de água: dificuldade de coagulação e floculação, baixa eficiência do processo de sedimentação, colmatação dos filtros, aumento do consumo de produtos para a desinfecção e ineficiência das operações de tratamento em relação à remoção de cianotoxinas. Esses problemas afetam negativamente a qualidade final da água distribuída para a população.

"A qualidade da água destinada ao consumo humano deve atender a uma série de requisitos, de maneira que não venha causar mal à saúde do homem, quer ela seja consumida por um certo período de tempo, quer ela seja consumida durante toda uma vida" (CAMPOS, 1994).

As estações convencionais de tratamento de água - coagulação, floculação, sedimentação, filtração e desinfecção - são ineficientes na remoção de contaminantes como praguicidas, alguns metais pesados e cianotoxinas. Para o tratamento de água com presença de cianobactérias alguns estudos em escala de laboratório, que usaram a sedimentação como processo de separação, apresentaram baixa eficiência de remoção de células e praticamente remoção alguma de cianotoxina.

Dada a maior necessidade de água em quantidade e qualidade e ao contraponto de a cada vez ser menos abundante a oferta de água economicamente potabilizavel, é muito importante que se busquem remover as células de cianobactérias sem que os processo e operações provoquem a lise celular e liberação das toxinas. Portanto tornam-se importantes as investigações 
acerca de sistemas que sejam eficientes não só na remoção desses microrganismos mas na remoção da toxina dissolvida.

A flotação por ar dissolvido constitui técnica moderna de tratamento de água que em comparação ao sistema mais utilizado atualmente para o tratamento de água - coagulação, floculação, sedimentação e filtração - apresenta significativas vantagens ao tratar água com elevadas concentrações de algas e cianobactérias. Dentre tais vantagens são citadas: compacticidade das instalações tendo em vista constituir processo de alta taxa; versatilidade operacional e rapidez de entrada em regime; produção de lodo já espessado; elevada eficiência de remoção de sólidos suspensos e, normalmente, requer menores quantidades de coagulante, resultando em menores produção de lodo que nos sistemas que utilizam a sedimentação (REALI, 1991; SANTOS E REALI, 1999).

A flotação por ar dissolvido (FAD), aplicada ao tratamento de água para abastecimento, vem sendo estudada desde 1981 dentro de linha de pesquisa estabelecida junto ao Departamento de Hidráulica e Saneamento da Escola de Engenharia de São Carlos - USP. Como parte dessa linha, o presente estudo tem como proposta a avaliação da remoção de microcistina de água eutrofizada submetida às diversas etapas de um sistema de tratamento em escala de laboratório envolvendo a pré-oxidação, a coagulação, a flotação por ar dissolvido e a adsorção em carvão ativado. 


\section{2 - OBJETIVOS}

Hipótese:

A presente pesquisa testa a hipótese de um sistema constituído de préoxidação, de coagulação/floculação, seguidos de flotação por ar dissolvido ter um bom desempenho no tratamento de água de abastecimento contendo alta concentração de algas e cianobactérias e com presença de microcistina. A adsorção em carvão ativado está em teste para verificar seu poder de remoção de toxina dissolvida no meio, que não removida com os processos anteriores.

\section{Objetivos:}

O objetivo precípuo dessa pesquisa é investigar as melhores condições e a influência da pré-oxidação e da coagulação/floculação com vistas à flotação por ar dissolvido, associadas ao carvão ativado, aplicada ao tratamento de água para abastecimento contendo cianobactérias e microcistina. 


\section{3 - REVISÃo BIBLIOGRÁFICA}

\section{1 - Eutrofização}

O processo conhecido por eutrofização das águas constitui uma das mais graves conseqüências da explosão demográfica e um dos mais sérios problemas da engenharia sanitária. A definição preferida por engenheiros e sanitaristas para eutrofização é o enriquecimento de corpos de água por nutrientes responsáveis por aumento de produtividade biológica.

Os termos eutrófico, mesotrófico e oligotrófico, em suas respectivas formas alemãs nährstoffreichere, mittehreiche e nährstoffarme, foram primeiramente usados em 1907 por C. A. Weber - com significados de bem nutrido ou rico em nutrientes (nährstoffreichere = eutrófico), semi nutrido (mittehreiche = mesotrófico) e mal nutrido ou pobre em nutrientes (nährstoffarme $=$ oligotrófico) - para descrever as condições de nutrientes determinadas pela natureza química dos solos pantanosos da Alemanha (HUTCHINSON, 1969; DUARTE, 1983).

As atividades humanas levam a usos múltiplos dos recursos hídricos tais como: abastecimento público, irrigação, uso industrial, navegação, recreação e 
aqüicultura. Embora essas atividades variem de acordo com o uso que a população faz do solo na bacia de drenagem e com a organização econômica e social da região, quaisquer que sejam as atividades em maiores ou menores proporções, elas geram impactos e deterioração da qualidade da água, assim como competem na quantidade de água disponível.

A eutrofização produz mudanças na qualidade de água, incluindo a redução de oxigênio dissolvido, a perda das qualidades cênicas, a morte extensiva de peixes e o aumento da incidência de florações de algas e cianobactérias.

A eutrofização pode ser natural ou artificial. Quando natural, é um processo lento e contínuo que resulta do aporte de nutrientes trazidos pelas chuvas e pelas águas superficiais que erodem e lavam a superfície terrestre. A eutrofização natural é também chamada de "envelhecimento natural" de um lago. Quando ocorre artificialmente, e de forma muito rápida, a eutrofização é denominada artificial, cultural ou antrópica e, neste caso, os nutrientes têm diversas origens como: efluentes domésticos, efluentes industriais, atividades agrícolas, entre outras (ESTEVES, 1998). Os engenheiros sanitaristas a denominam eutrofização acelerada.

Ecólogos adotaram o adjetivo "eutrófico" para descrever sistemas em que há um alto acréscimo de nutrientes limitantes (nitrogênio, fósforo, carbono), os quais promovem elevado nível de produção orgânica (REYNOLDS, 1987).

A eutrofização passou a ser reconhecida como um problema de poluição em muitos lagos e reservatórios europeus e norte-americanos a partir de meados do século vinte. Desde então o problema tem se agravado, especialmente em 
algumas regiões de clima quente, causando deterioração no meio aquático e promoção de sérios problemas para o uso da água, particularmente para o consumo humano (CHORUS \& BARTRAM, 1999). Neste contexto, cabe salientar ainda o fato de, geralmente, os processos de eutrofização favorecerem o crescimento de algas e cianobactérias, muitas delas tóxicas (GAETE et al., 1994).

\section{2 - Florações, Cianobactérias e suas Toxinas}

\subsection{1 - Características das Cianobactérias}

A origem das cianobactérias, provavelmente os primeiros produtores primários de matéria orgânica a liberarem oxigênio elementar na atmosfera primitiva, foi estimada em cerca de 3,5 bilhões de anos (CARMICHAEL, 1994).

Seus fósseis datam do período pré-cambriano. Ao longo das eras uma grande flexibilidade e adaptações bioquímicas, fisiológicas, genéticas e reprodutivas garantiram aos organismos a sua perpetuação na superfície terrestre e sua distribuição em diversos ambientes terrestres, aquáticos - rios, estuários e mares - e na interface úmida da terra com o ar - rochas, cascas de árvores, paredes, telhados, vidros, etc.

As cianobactérias exibem uma combinação de propriedades encontradas tanto em algas como em bactérias; em termos evolutivos, são consideradas como organismos intermediários entre as bactérias e os vegetais, pois deram origem ao cloroplasto das plantas. Assemelham-se às bactérias por serem organismos 
procariontes, caracterizados pela ausência de membrana nuclear. No entanto, seu principal modo de nutrição, a fotossíntese, que envolve liberação de oxigênio, é similar ao de todas as algas nucleadas ou eucarióticas e de plantas superiores. Seus processos vitais requerem somente água, dióxido de carbono, substâncias orgânicas e luz (CHORUS \& BARTRAM, 1999; ESTEVES, 1988; REYNOLDS, 1987).

Possuem como pigmentos principais a ficocianina - daí a antiga designação algas azuis - e clorofila-a. A sua reserva glicídica ocorre sob a forma de glicogênio (WHITTON \& POTTS, 2000).

Podem ser classificadas taxonomicamente como pertencentes ao reino Procaryotae, formado por todos os organismos procariontes. Possui apenas uma classe, Cyanophyceae, composta por, aproximadamente, 150 gêneros e 2000 espécies (HOEK et al., 1995). Apesar de ser um grupo relativamente pequeno, são únicas em suas características, representando papel fundamental na biota pela importância de seus processos fisiológicos para toda cadeia trófica dos ecossistemas onde ocorrem.

Compreende formas unicelulares (Chroococcus, e Gloeocapsa, por exemplo); filamentosas (Anabaena, Nostoc e Oscillatoria, por exemplo); e coloniais não filamentosas (Microcystis e Aphanothece, por exemplo). Seu único meio de reprodução é assexuado. Calijuri et al. (2002) descreve a Microcystis aeruginosa como uma S-estrategista, especialista em estocagem de fosfato e regulador de densidade, que lhe confere a habilidade em flutuar. 

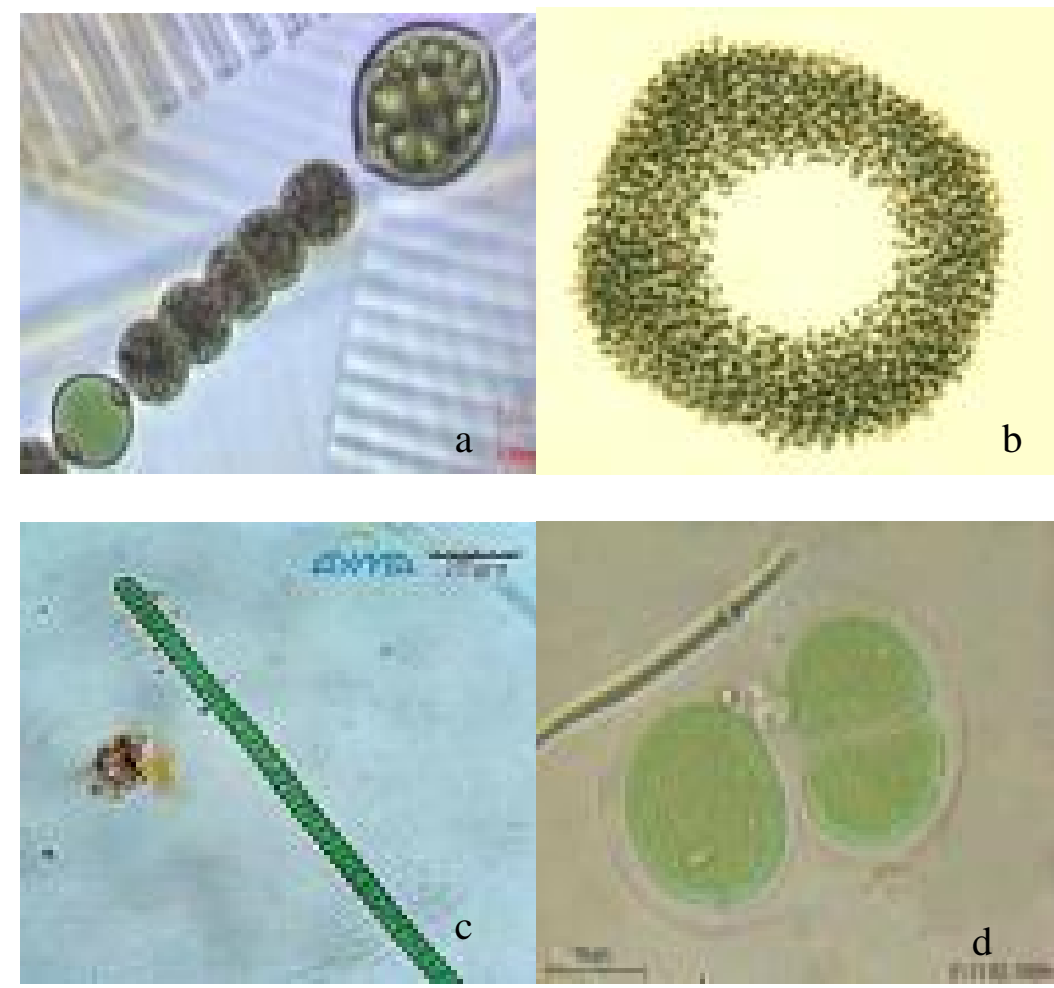

Figura 3.1 - Exemplos de cianobactérias (a) Anabaena, (b) Microcystis, (c) Oscilattoria e (d) Chroococcus.

Entre os fatores que levam as cianobactérias a predominarem sobre os outros grupos fitoplanctônicos, destacam-se as características fisiológicas de assimilação dos nutrientes do meio aquático. As cianobactérias são menos eficientes do que as algas para assimilar esses nutrientes, que em condições normais crescem mais e melhor. No entanto a excessiva descarga de nutrientes nos reservatórios propicia maior oferta dos referidos nutrientes, facilitando sua assimilação e o crescimento das cianobactérias (MINISTÉRIO DA SAÚDE, 2003). 


\subsection{2 - Florações}

Expostas a condições específicas, especialmente águas ricas em nutrientes, temperaturas elevadas e luz solar, as algas e cianobactérias multiplicam-se de forma acelerada e causam as florações (CHARMICHAEL, 1992). Essas florações caracterizam-se por um crescimento explosivo, autolimitante e de curta duração, freqüentemente produzindo colorações visíveis nos corpos de água naturais (MATTHIENSEN, 1996). Em muitos casos, as florações podem ser dominadas por duas, três ou mesmo uma única espécie (REYNOLDS, 1987).

Em determinadas fases as florações tornam-se superficiais especialmente se as condições atmosféricas forem estáveis, com ausência de vento e chuva. Tal fato é devido à capacidade das cianobactérias flutuarem na superfície, uma vez que possuem vesículas gasosas.
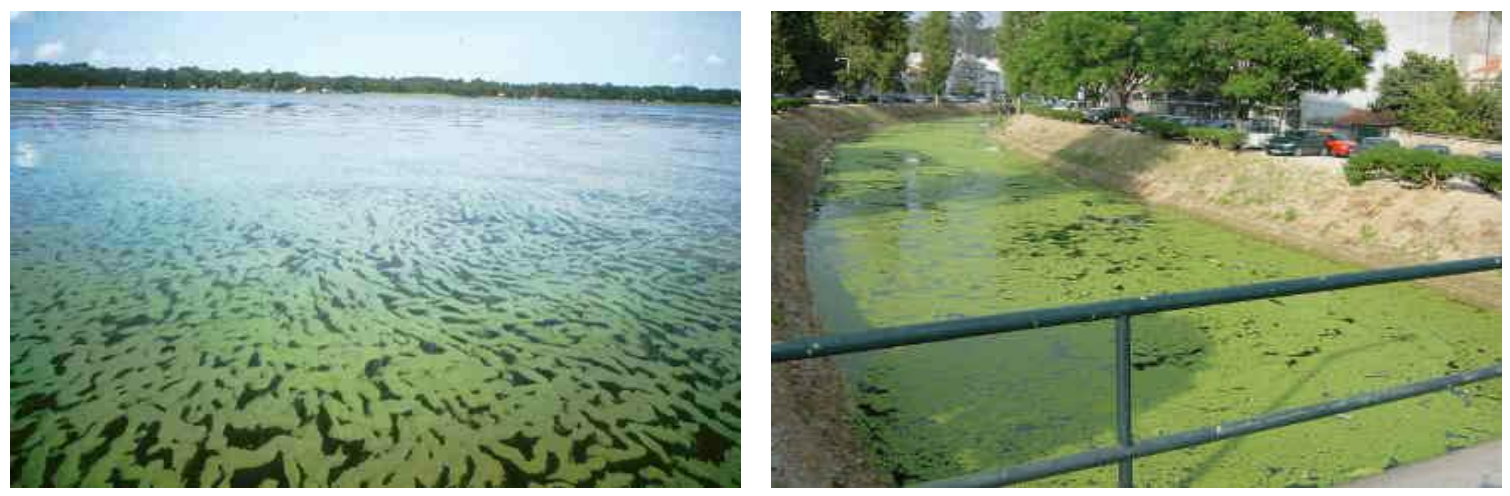

Figura 3.2 - Fotos com exemplos de florações em um lago (à esquerda) e em um rio (à direita). 
Ambientes de água doce são os mais favoráveis para o crescimento de cianobactérias porque a maioria das espécies apresenta melhor crescimento em águas neutroalcalinas (pH 6-9), temperatura entre $15{ }^{\circ} \mathrm{C}$ a $30{ }^{\circ} \mathrm{C}$ e alta concentração de nutrientes.

O Ministério da Saúde (2003) reporta que a principal preocupação com o aumento da ocorrência de florações de cianobactérias em mananciais de abastecimento de água é a capacidade desses microrganismos produzirem e liberarem para o meio líquido toxinas que podem afetar a saúde humana e causar surtos e epidemias que se caracterizam como problemas de saúde pública.

\subsection{3 - Microcistina}

Se as cianobactérias estiverem presentes ou forem dominantes durante o ano todo, os problemas práticos são associados à alta biomassa e à potencial ameaça à saúde por suas toxinas (CHORUS \& BARTRAM, 1999).

O crescimento intenso desses microrganismos na superfície da água geralmente acontece com predomínio de poucas ou mesmo de apenas uma espécie de cianobactéria produtora de toxina, que inibe sua predação por microcrustáceos, larvas de peixes, moluscos etc. Esses consumidores primários vão preferir consumir as algas não tóxicas e com maior valor nutricional, com isso contribuem para a redução das populações dessas algas e, conseqüentemente, reduzem a competição entre esses organismos (MINISTÉRIO DA SAÚDE, 2003)

De acordo com Sant'Anna e Azevedo (2000) foram registradas ocorrências de cerca de 20 espécies de cianobactérias tóxicas, incluídas em 14 gêneros, em 
diferentes ambientes aquáticos brasileiros, destacando-se a espécie Microcystis aeruginosa e o gênero Anabaena.

De acordo com suas estruturas químicas, as cianotoxinas podem ser incluídas em três grandes grupos: peptídeos cíclicos, alcalóides e lipopolissacarídeos. Entretanto, por sua ação farmacológica, as principais classes de cianotoxinas caracterizadas até o momento são: neurotoxinas, hepatotoxinas e os lipopolissacarídeos (CHORUS \& BARTRAM, 1999). Microcystis aeruginosa, Microcystis viridis, Aphanizomenon flos-aquae e Anabaena sp estão todas associadas à produção de microcistina, a mais comum toxina encontrada em cianobactérias (HITZFELD et al., 2000). Os sintomas apresentados por animais intoxicados inclui fraqueza, palidez, extremidades frias, respiração pesada, vômitos e diarréia (CODD, 2000).

Os mecanismos de toxicidade das microcistinas envolvem a inibição da enzima fosfatase em células eucarióticas. No fígado esses efeitos bioquímicos causam ruptura na estrutura das células (BAKER \& FABBRO, 1999). Essas hepatotoxinas, que chegam aos hepatócitos por meio dos ácidos biliares, promovem uma desorganização do citoesqueleto dos hepatócitos. Como conseqüência, o fígado perde sua arquitetura e desenvolve graves lesões internas. A perda de contato entre as células cria espaços internos que são preenchidos pelo sangue que passa a fluir dos capilares para esses locais, provocando uma hemorragia intra-hepática (CHARMICHAEL, 1994).

A microcistina-LR é o tipo mais comum das microcistinas. Essa toxina contém cinco aminoácidos não variáveis e dois variáveis. A estrutura química da 
microcistina-LR está apresentada na Figura 3.3. Os aminoácidos invariáveis são: D-alanina (Ala - 1), D-eritro-B-ácido metilasparato (Masp - 3), D-ácido glutâmico (Glu - 6), N-metildehidroalanina (Mdha - 7) e 3-amino-9-metoxi-2,6,8-trimetil-10fenil-4,6-ácido dienóico (Adda - 5). No caso da microcistina-LR os dois aminoácidos variáveis são leucina $(L-2)$ e arginina ( $R$ - 4); outras microcistinas possuem combinações de um desses aminoácidos com outros aminoácidos ou com dois outros diferentes destes (PENDLETON et al., 2001).

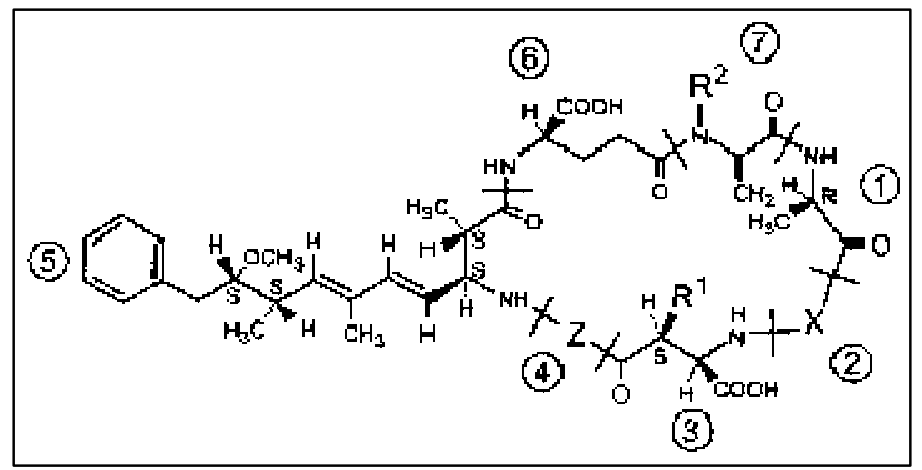

Figura 3.3 - Estrutura química da molécula de microcistina-LR (Fonte: CHORUS \& BARTRAM, 1999).

Assim como muitas toxinas, a microcistina recebeu esse nome porque foi primeiramente identificada de Microcystis; estudos posteriores porém mostraram que outras cianobactérias também a produzem (CHORUS \& BARTRAM, 1999). Acredita-se que a produção de toxinas seja uma das estratégias de sobrevivência desses organismos, como um modo de defender-se de predadores e competidores (PÁDUA, 2002). 
A toxicidade dessa toxina apresenta dose letal $\left(D_{50}\right)$ entre 25 e $150 \mu \mathrm{g} / \mathrm{kg}$ de peso corpóreo quando injetado e entre 5.000 e $10.900 \mu \mathrm{g} / \mathrm{kg}$ de peso corpóreo por ingestão oral em animais de laboratório (CHORUS \& BARTRAM, 1999). A Portaria 518 de 20/03/2004, que substituiu a Portaria 1469 de 29/12/2000, do Ministério da Saúde, estabeleceu como padrões de potabilidade de água os limites de $1,0 \mu \mathrm{g} / \mathrm{L}$ para microcistinas, 3,0 $\mu \mathrm{g} / \mathrm{L}$ para saxitoxinas e $15 \mu \mathrm{g} / \mathrm{L}$ para cilindropermopsinas. O valor máximo aqui estabelecido para a microcistina é igual ao que foi sugerido pela World Health Organization (WHO, em português Organização Mundial da Saúde), e difere do padrão australiano de 1,3 $\mu \mathrm{g} / \mathrm{L}$.

A espécie Microcystis aeruginosa é a mais amplamente distribuída no Brasil e Anabaena é o gênero com o maior número de espécies potencialmente tóxicas; a saber: A. circinalis, A. flos-aquae, A. planctonica, A. solitaria e A. spiroides (SANT'ANNA e AZEVEDO, 2000).

As células se rompem e liberam toxina, quando digeridas por outros organismos, por ação de agentes químicos e processos físicos e na fase senescente (CHARMICHAEL, 1994).

Baker \& Fabbro (1999) sugerem um método empírico de monitoramento de microcistina em fontes de água, onde não há a possibilidade de medição por métodos consagrados. Em situações que ocorrem $M$. aeruginosa em fontes de água potável o número de células pode ser usado para ter-se uma orientação preliminar de potencial de risco para a Saúde Pública. Como uma indicação, para uma população altamente tóxica de $M$. aeruginosa uma densidade de aproximadamente 6.500 células $/ \mathrm{mL}$ é equivalente à $1,0 \mu \mathrm{g} / \mathrm{L}$ de microcistina, se 
toda a toxina for lançada na água. Deve-se comentar aqui que esse método proposto pelos autores não deve ser aplicado à risca em águas naturais já que as análises feitas para essa aproximação utilizaram culturas de cianobactérias. Em culturas as células não têm a tendência de formação de colônias o que facilita a contagem. Em águas naturais essas colônias são presentes o que dificulta a identificação de células isoladas.

A mais antiga notícia que relata envenenamento por cianotoxinas pode ter sido há cerca de 1000 anos pelo General Zhu Ge-ling que reportou mortalidade em tropas que beberam água que "estava verde" de um rio no sul da China (CHORUS \& BARTRAM, 1999).

\section{3 - Problemas Atribuídos à Algas e Cianobactérias em Estações de Tratamento de Água}

Os problemas causados por águas contendo algas e cianobactérias em estações de tratamento de água para abastecimento segundo o Ministério da Saúde (2003) são: dificuldade de coagulação e floculação, baixa eficiência do processo de sedimentação, colmatação dos filtros e aumento da necessidade de produtos para a desinfecção. Como conseqüência desses problemas operacionais, verifica-se, geralmente, a redução na eficiência dos processos de tratamento e o surgimento de problemas na água tratada associados à presença de algas, cianobactérias e seus subprodutos extracelulares. 
Santos (1997) comenta a dificuldade da remoção de algas em sistemas convencionais de tratamento de água, pois a presença das mesmas, além de conferir sabor e odor as águas de abastecimento, causa uma série de problemas operacionais nas diversas etapas do processo destacando-se a colmatação precoce do meio filtrante. Essa colmatação deve-se ao fato dos flocos formados após coagulação/floculação apresentarem baixa densidade e, por conseqüência, pequenas velocidades de sedimentação, ou, às vezes, até mesmo a tendência à flutuação. (REALI \& SANTOS, 1999).

Os processos e seqüências de tratamento de água para abastecimento público devem ser analisados em função da sua capacidade de remover as células viáveis - biomassa algal - e de não promover a lise dessas células. Isso se deve à ineficiência dos processos em remover a parte dissolvida da toxina no meio líquido.

Para as dosagens usualmente adotadas nos tratamentos convencionais, as células de cianobactérias, mais especificamente Microcystis, não são danificadas no processo de coagulação/floculação. Ao mesmo tempo observa-se que no lodo produzido nos processos de separação, ocorre a liberação de toxinas (MINISTÉRIO DA SAÚDE, 2003). Em trabalho citado por Hudrey et al. (1999), após dois dias, toda a toxina das células de Microcystis aeroginosa presentes em um lodo coletado numa instalação piloto de tratamento havia sido liberada para o meio líquido. Essas observações têm implicações práticas no que tange ao tempo de acumulação do lodo nos decantadores e nos adensadores de lodo, particularmente quando a água clarificada nessas unidades é retornada para o 
processo de tratamento. Nesse caso, com a água retornando ao início da estação, haveria um aumento da concentração devido à toxina presente na água retornada somada à toxina da água que entra na estação.

As cianobactérias exibem característica que torna totalmente ineficiente o uso do processo de sedimentação em uma estação de tratamento de água. Esses organismos possuem vacúolos intracelulares que os concede a habilidade para flutuar no meio líquido. Assim, as células que passam pelo decantador da estação vão se acumular nos filtros, causando a colmatação e conseqüente diminuição das carreiras de filtração.

Existem vários estudos sobre a eficiência da adsorção do carvão ativado na remoção de toxinas, mas essa eficiência depende de um excelente resultado das etapas anteriores ao carvão em relação à remoção de matéria orgânica e substâncias húmicas já que esse material compete com a microcistina pelos sítios de adsorção do carvão (PENDLETON et al., 2001). E, como dito antes, a presença das algas causa a redução da eficiência das etapas de tratamento. Esse fato encarece e, às vezes, torna inviável financeiramente o uso do carvão ativado.

Di Bernardo (1995) descreve inúmeros problemas relacionados com a presença de algas e cianobactérias nos diversos níveis da estação de tratamento como interferência na coagulação, corrosão do concreto e aço das unidades de tratamento, aumento da quantidade de lodo, persistência no sistema de distribuição além de aumento de cor e presença de odor e gosto na água. 


\section{4 - Oxidação}

Oxidação é o nome dado ao processo quando há aumento do estado de oxidação de uma substância. Na reação de oxidação, que ocorre simultaneamente com a de redução, as substâncias orgânicas doam elétrons, ganham oxigênio e perdem hidrogênio. De modo geral, no tratamento de água, a oxidação tem como objetivo converter substâncias indesejáveis em substâncias não prejudiciais ou não objetáveis (POSSELT \& WEBER JR. ${ }^{1}$ apud. MINISTÉRIO DA SAÚDE, 2003). Os oxidantes mais usados no tratamento de água são o cloro, o dióxido de cloro, os hipocloritos de sódio e de cálcio, o permanganato de potássio, o oxigênio e o ozônio.

Geralmente o grau de degradação de um composto orgânico por um oxidante, segundo Anselme et al. (1992), depende de muitos fatores incluindo (1) a força do oxidante, (2) o modo como o oxidante ataca as ligações do composto, (3) a estrutura dos compostos e (4) fatores do meio como $\mathrm{pH}$, temperatura, concentração de substâncias químicas e a presença de substâncias que interferem na reação de oxidação. A literatura e ensaios em laboratório sugerem que os oxidantes a base de cloro não são efetivos para remover compostos orgânicos com moléculas de baixo peso molecular.

A seguir são descritas algumas características de alguns dos oxidantes usados para tratamento de água conforme a Water Environment Federation, (1996):

\footnotetext{
${ }^{1}$ POSSELT, H. S. \& WEBER JR., W. J. (1972). Chemical Oxidation. In: WEBER JR., W. J. (editor). Physicochemical Processes for Water Quality Control. Wiley-Interscience.
} 
- Cloro $\left(\mathrm{Cl}_{2}\right)$ : Membro da família do halógenos é altamente reativo e sob condições específicas reage com muitos compostos e elementos muitas vezes imediatamente. O cloro remove hidrogênio de alguns compostos devido à sua afinidade por esse elemento. Cloraminas são compostos formados pela reação do cloro com amônia ou outras substâncias nitrogenadas. Dissolvido na água, o cloro forma uma solução corrosiva contendo mistura de ácido clorídrico $(\mathrm{HCl})$ e ácido hipocloroso $(\mathrm{HOCl})$.

- Hipocloritos. São sais de ácido hipocloroso com característica de fortes oxidantes. Hipoclorito de sódio $(\mathrm{NaOCl})$ é a única forma de hipoclorito líquido. Hipoclorito de cálcio $\left(\mathrm{Ca}(\mathrm{OCl})_{2}\right)$ é predominantemente sólido. Hipoclorito de sódio tem aparência amarelada, é altamente alcalino e corrosivo e tem forte odor de cloro. É altamente instável com degradação acelerada por calor, luz e longo tempo de estocagem. É destrutivo para madeira, corrosivo para a maioria dos metais e afeta negativamente, olhos, pele e outros tecidos do corpo que estiverem em contato.

Os oxidantes são empregados no tratamento de água a fim de controlar o gosto e o odor, manter os filtros mais limpos, remover o ferro e o manganês, destruir o sulfeto de hidrogênio, diminuir a cor, controlar o crescimento bacteriano nas redes, desinfetar adutoras, aprimorar a floculação, oxidar amônia na proteção de membranas filtrantes e controlar algas no pré-tratamento (DANIEL, 2001; CHORUS \& BARTRAM, 1999). 
Na literatura são apresentados resultados de pré-tratamento com oxidantes, mostrando que esses produtos melhoram a coagulação e, principalmente, aprimoram a remoção de algas, cianobactérias, toxinas e outras partículas de matéria orgânica nas unidades subseqüentes de tratamento.

Ma \& Liu (2001) estudaram o efeito de cloro, ozônio e dióxido de cloro em águas contendo culturas de Scenedesmus sp. A atividade algal e a concentração de clorofila diminuíram e a concentração de substâncias orgânicas dissolvidas aumentou com maiores concentrações dos oxidantes. O coagulante utilizado foi o sulfato de alumínio e o pré-tratamento com dióxido de cloro (1, 3 ou $5 \mathrm{mg} / \mathrm{L})$ melhorou o efeito da coagulação, enquanto a pré-cloração com cloro (10 ou 20 $\mathrm{mg} / \mathrm{L}$ ) aumentou a dosagem requerida de coagulante em $15 \%$.

A inativação de endotoxinas derivadas de Escherichia coli foi testada por Anderson et al. (2003) com o auxílio de três substâncias - cloro, monocloramina e permaganato de potássio - usadas tanto como desinfetantes como oxidantes em águas de abastecimento. Esses compostos são também usados no controle de sabor, odor e crescimento de cianobactérias, para inativar microcistinas, e para facilitar a remoção de ferro e manganês.

A pré-oxidação foi estudada, em escala piloto, por Lage Filho e Ferreira Filho (1997) em tratamento de águas eutrofizadas. Os autores concluíram que, por promover a formação de flocos mais resistentes, a pré-oxidação com cloro livre atuou como um auxiliar de coagulação, proporcionando melhor remoção de cor aparente e melhor remoção de carbono orgânico total e substâncias húmicas oriundas de matéria orgânica decomposta. 
Tsuji et al. (1997) estudaram o efeito da cloração de água com presença de cianobactérias e microcistinas e sugerem que os resultados mostram que a cloração em dosagem adequadas é efetiva para remoção de microcistina em águas naturais. A concentração de $2,8 \mathrm{mg} / \mathrm{L}$ de cloro livre por 30 minutos removeu $99 \%$ de microcistina-LR confirmando os resultados obtidos por Nicholson et al. (1994) que mostraram que a microcistina foi facilmente decomposta por cloração.

\subsection{1 - Cloração no Breakpoint}

Quando o cloro ou seus compostos derivados é adicionado em água pura forma-se cloro disponível - cloro livre. Quando é adicionado em água natural o cloro reage com outros compostos antes de formar cloro livre. O cloro reage inicialmente com compostos orgânicos e inorgânicos. Após essa demanda inicial o cloro (como $\mathrm{HOCl}$ ) então combina-se com a amônia disponível $\left(\mathrm{NH}_{3}\right.$ ou $\left.\mathrm{NH}_{4}\right)$ para formar cloraminas. Os diferentes tipos de cloraminas são geralmente chamados "residuais combinados". Adicionando cloro após toda a amônia ser combinada causa oxidação das cloraminas. Quando cloro suficiente é adicionado para a completa oxidação destes compostos ocorre o breakpoint. Adicionar cloro além desse ponto resultará em formação de cloro disponível. 


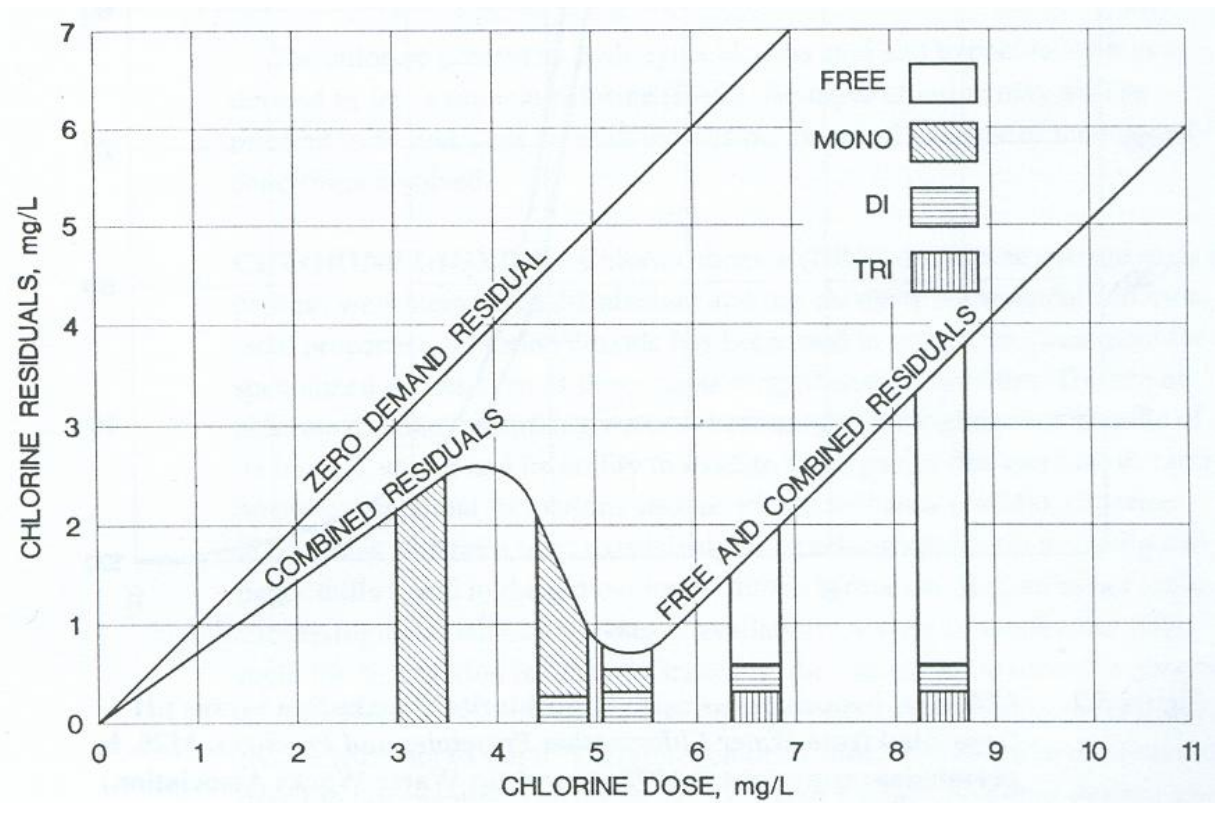

Figura 3.4 - Curva de cloro residual em relação à dosagem de cloro adicionada. (FONTE: WATER ENVIRONMENT FEDERATION, 1996)

\subsection{2 - Formação de Trihalometanos}

Apesar dos aspectos positivos do uso do cloro como oxidante, a aplicação do cloro em águas contendo substâncias húmicas leva à formação de compostos organoclorados prejudiciais à saúde humana, destacando-se os trihalometanos.

Segundo Di Bernardo (1993), os precursores da formação de trihalometanos (THM) e de outros compostos organoclorados não voláteis são:

- $\quad$ pigmentos (clorofila);

- produtos da decomposição de plantas (ácidos húmicos e fúlvicos);

- biomassa de algas;

- amino ácidos;

- proteínas e; 
- efluentes industriais (fenóis).

Os trihalometanos incluem compostos de clorofórmio $\left(\mathrm{CHCl}_{3}\right)$; bromofórmio $\left(\mathrm{CHBr}_{3}\right)$; os dois intermediários bromoclorofórmio: bromodiclorometano $\left(\mathrm{CHBrCl}_{2}\right)$ e o dibromoclorometano $\left(\mathrm{CHBr}_{2} \mathrm{Cl}\right)$; e dicloroiodometano $\left(\mathrm{CHICl}_{2}\right) \cdot \mathrm{A}$ Portaria 518 de 25 de março de 2004, estabelece para nível máximo de trihalometanos 0,1 $\mathrm{mg} / \mathrm{L}$

\section{5 - Coagulação/Floculação}

A coagulação é resultado de dois fenômenos, o primeiro essencialmente químico e o segundo fundamentalmente físico. O fenômeno químico consiste nas reações do coagulante com a água e na formação de espécies hidrolisadas com carga positiva e depende da concentração do metal e do $\mathrm{pH}$ final da mistura. $\mathrm{O}$ fenômeno físico consiste no transporte das espécies hidrolisadas para que haja contato com as impurezas da água (DI BERNARDO, 1993).

Após a coagulação as partículas possuem tamanhos na faixa entre 0,5 e 5 $\mu \mathrm{m}$ e são denominadas partículas primárias. Na floculação, as partículas primárias agregam-se em conseqüência das colisões promovidas, ocorrendo a formação de flocos maiores, na faixa entre $100 \mu \mathrm{m}$ e $5000 \mu \mathrm{m}$. Na coagulação, o processo, que é consumado em questão de segundos, relaciona-se à aspectos químicos e na 
floculação, e separação dos flocos, em etapas que demandam tempo superior a alguns minutos, prevalecem os aspectos físicos.

A influência da dosagem de coagulante foi estudada por Montiel \& Welté (1998) para remoção de algas. Os resultados são mostrados na Tabela 3.1. Os autores estudaram, também, o tempo de floculação e em 15 minutos de floculação os obtiveram remoção de turbidez de $91-93 \%$ para dosagens de cloreto férrico de 20 e 30 mg/L. Comparado à remoção quando não houve floculação -remoção de turbidez de 73-74\% - ou seja, a água sofreu flotação logo após a coagulação, o que mostrou ter havido melhora razoável apenas com a floculação.

O tempo de floculação também influenciou a remoção de algas. Para tempos de floculação de 15 e 38 minutos, a porcentagem de remoção de algas foi de 63 e 46\%, respectivamente. Ou seja, tempos muitos longo podem influenciar negativamente.

Tabela 3.1 - Remoção de turbidez e clorofila com variação de dosagem de coagulante.

\begin{tabular}{ccc}
\hline Dosagem de & \multicolumn{2}{c}{ \% Remoção } \\
\cline { 2 - 3 } Cloreto Férrico (mg/L) & Turbidez & Clorofila \\
\hline 12 & 51 & 83 \\
24 & 81 & 92 \\
50 & 81 & 93 \\
82 & 73 & 95 \\
\hline
\end{tabular}

Fonte dos Dados: MONTIEL \& WELTÉ (1998)

Os resultados da Tabela 3.1 mostram não haver necessidade de grandes dosagens de coagulante para se ter remoção satisfatória de turbidez e clorofila e que o aumento da dosagem de coagulante não promove significativo aumento de remoção. 


\section{6 - Flotação por Ar Dissolvido}

Os conceitos básicos da flotação tiveram origem na área de mineração há muitos anos. Fora dessa área as primeiras aplicações da flotação foram feitas por volta de 1920 na indústria de papel e celulose, com a finalidade de recuperar as fibras de madeira do efluente, o que resultou também na diminuição da carga poluidora.

A flotação de dispersões aquosas apresenta como princípio a separação de fases com uso de agentes com baixa densidade, normalmente bolhas de gás, as quais aderem à superfície das partículas dispersas, aumentam o empuxo sobre as mesmas, e promove a separação (REALI, 1991).

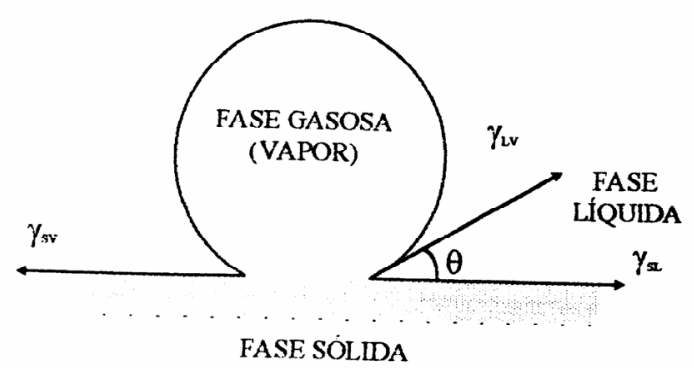

Figura 3.5 - Ângulo de contato entre uma fase sólida e uma fase gasosa imersa numa fase líquida.

Edzwald (1995) cita como possível mecanismo para formação de agregados de bolhas e partículas, a colisão da partícula e a adesão às bolhas préformadas. Classicamente, o ângulo de contato entre a bolha aderida e a partícula, é usado para descrever a flotação de partículas. O ângulo de contato $(\theta)$ deve ser 
finito e grande o bastante para que a energia de aderência da água na partícula sólida seja menor que a energia de coesão da água.

Segundo Hyde ${ }^{2}$ et al. apud REALI (1991), a flotação pode ser classificada segundo a técnica aplicada na geração das bolhas de gás - normalmente o ar - e essas modalidades são classificadas em três grupos:

- Flotação por Ar Disperso: Este tipo envolve o uso de violenta agitação, usualmente através de rotores para promover a dispersão, aeração e agitação do líquido a ser processado. O sistema é utilizado com freqüência no setor de refinação de minérios, $95 \%$ dos metais do mundo são processados por flotação.

- Flotação Eletrolítica: Com o auxílio de corrente elétrica entre pares de eletrodos, colocados no fundo do reator, há no interior do meio líquido geração de microbolhas de oxigênio e hidrogênio provenientes da eletrólise da água.

- Flotação por Ar Dissolvido (FAD): Nessa modalidade de flotação não é usada agitação violenta. As bolhas de gás são formadas através da liberação de gás previamente dissolvido sob pressão na água, após diminuição dessa pressão à qual o líquido está submetido. De acordo com a maneira que é promovida a diminuição da pressão, a flotação por ar dissolvido pode ser dividida em Flotação à Vácuo e FAD por Pressurização. Na Flotação à Vácuo, o fluxo líquido a ser tratado por flotação é submetido a um processo de simples aeração (com o líquido sujeito à pressão

${ }^{2}$ HYDE. R. et al (1977). Water Clarification by Flotation. Journal AWWA. P.369-374. 
atmosférica) e, em seguida é encaminhado a uma câmara de vácuo, no qual o ar é liberado devido à queda de pressão. Na Flotação por Ar Dissolvido por pressurização, o líquido é encaminhado a uma câmara de pressurização - submetida a uma pressão maior que a atmosférica - onde é promovida a dissolução do gás no líquido. Após a pressurização, o líquido saturado é submetido a uma pressão próxima à atmosférica ocorrendo então a liberação das bolhas de gás. Esta técnica possui vantagem em relação a flotação à vácuo, por permitir maior diferença de pressão e possibilitar que seja liberado maior quantidade de gás.

Das modalidades citadas a mais amplamente utilizada na área do saneamento é a FAD. As microbolhas geradas por esse processo, com diâmetro em torno de $50 \mu \mathrm{m}$, têm a finalidade de aderir às partículas ou aos flocos, resultando um agregado com densidade suficientemente inferior à densidade da água e, assim, proporcionar deslocamento ascensional ao agregado.

Para a remoção de algas de a flotação é usada por ser, geralmente, considerada uma técnica mais vantajosa que a sedimentação (CHEN et al., 1998). A clarificação de água contendo algas pelo processo de sedimentação é ineficiente devido à baixa densidade das células algais e dos flocos produzidos pela coagulação e floculação dessas águas (EDZWALD \& WINGLER, 1990).

Segundo esses autores, para melhorar a sedimentação seriam necessárias algumas medidas como diminuição da taxa de aplicação superficial, aumento do tempo de floculação para os flocos atingirem tamanho adequado para sedimentar 
e aumento das dosagens de coagulantes e auxiliares de floculação. Porém, essas medidas acarretariam aumento do tamanho das unidades da estação, aumento de custos e da quantidade de lodo - com conseqüentes custos adicionais.

Os tanques de flotação são menores que os de sedimentação devido à diferença de taxas de aplicação superficial entre os processos. Para a sedimentação as taxas usadas para dimensionamento estão na faixa de 25 a 45 $\mathrm{m}^{3} / \mathrm{m}^{2} /$ dia (NBR 12216, 1992), enquanto para flotação essas taxas estão na faixa de 120 a $180 \mathrm{~m}^{3} / \mathrm{m}^{2} /$ dia e para flotação de alta taxa os valores são de 360 a 960 $\mathrm{m}^{3} / \mathrm{m}^{2} /$ dia. Os custo de energia e manutenção para a flotação são maiores devido aos compressores, mas a economia apresentada, dado o menor tamanho das unidades, às baixas dosagens de coagulante e auxiliares de floculação e menor volume de lodo produzido compensam.

Reali (1991) comenta que a partir da década de 70 a idéia da aplicação do processo de $F A D$ na clarificação de águas de abastecimento, em substituição à sedimentação, conquistou de forma crescente o interesse dos pesquisadores da área. $\mathrm{O}$ uso da FAD como etapa para clarificação precedendo o processo de filtração, em um sistema de tratamento de água de abastecimento, tem sido comprovado e recomendado especialmente para certos tipos de água, como por exemplo: águas com alto teor de algas e águas com alta cor e baixa turbidez.

O mesmo autor, juntamente com outros colaboradores, em trabalho de 1993 estudou a clarificação da água bruta contendo alta concentração de algas em suspensão, empregando uma unidade de flotação de ar dissolvido em escala 
de laboratório. Nesse estudo os autores obtiveram eficiência de remoção de algas superior a $97 \%$.

Lacerda (1997) concluiu que o processo de flotação por ar dissolvido possui alto potencial de remoção de algas desde que sejam garantidas condições ideais de coagulação; parecem ser mais adequados maiores valores de tempo de floculação.

Santos e Reali (1999) concluem, em seu estudo com unidade de flotação de alta taxa, que essa alternativa de tratamento é eficiente para água bruta contendo alto teor de algas em suspensão, podendo-se operar com alta taxa e menores quantidades de ar que usualmente são exigidas em unidades convencionais de flotação - desde que a coagulação e a floculação sejam realizadas adequadamente.

Chorus \& Bartram (1999, capítulo 9, item 9.3.4) apresentaram resultados de vários autores com dados de estações piloto e em estações reais de flotação, com boa eficiência. Os resultados mostram redução de até $98 \%$ em células algais em geral. Para células de Microcystis, apresentaram resultados de remoção de $76,5 \%$ e de $80 \%$ em uma estação belga, onde, além de Microcystis, obteve também remoção de $100 \%$ para células de Anabaena.

O resultado da filtração não é influenciado pela presença de bolhas de ar na água flotada. De acordo com Reali (1991), tais bolhas além de contribuírem para a oxidação dos metais dissolvidos na água - ferro e manganês, por exemplo provavelmente permitem a remoção, por arraste, de parcela dos contaminantes voláteis, se presentes na água. 


\section{7 - Carvão Ativado}

Têm sido encontrados na água cerca de setecentos compostos orgânicos derivados de várias atividades industriais, municipais e da agricultura assim como de decomposição natural de matéria orgânica animal e vegetal. A tecnologia de adsorção é correntemente usada para remover micropoluentes orgânicos e inorgânicos da solução aquosa e desde sua introdução, em 1940, o carvão ativado tornou-se o adsorvente padrão para atender às condições de potabilidade de água (POLLARD et al., 1992). A AWWA (1991) define adsorção como processo pelo qual moléculas são concentradas na superfície por forças químicas físicas ou ambas.

Carvão ativado é o nome dado ao grupo de carvões porosos, manufaturado pelo tratamento com queima de gases ou por carbonização de materiais carbonáceos com ativação química simultânea. Todos esses carvões são preparados para exibirem alto grau de porosidade e extensa área superficial interna (MARSH et al., 1997). Segundo definição dada pela AWWA (1991) o carvão ativado é uma família de substâncias carbonáceas manufaturadas por processo que desenvolve porosidade interna, desse modo criando propriedades de adsorção.

Materiais carbonáceos costumam ser classificados em dois grupos. $\mathrm{O}$ carvão ativado está incluído no grupo conhecido como "carbonos amorfos". Em outro grupo, "carbonos cristalinos", está incluso, entre outros, o diamante (SMISEK \& CERNY, 1970). 
O uso de carvão ativado na forma de madeira carbonizada foi descrito por volta de 1550 a.C. em um antigo papiro egípcio. O primeiro carvão ativado manufaturado industrialmente foi um carvão descolorante produzido desde 1909, de acordo com a patente de R. V. Ostrelko; aquecendo madeira carbonizada com vapor e dióxido de carbono em um forno especial.(MARSH et al., 1997).

O uso de carvão simples para a filtração de água tornou-se popular antes da virada do século XIX para o século XX. No entanto, arqueólogos encontraram evidências que indicaram seu uso para esse fim desde antes do nascimento de Cristo. O que chama-se atualmente carvão "ativado" foi primeiramente usado para tratar água antes da Primeira Guerra Mundial e seu desenvolvimento foi significativamente avançado, durante a guerra, para prover água potável em pequenas quantidades para tropas no front (LEHR, 1991). Nos Estados Unidos, durante a guerra citada, foi desenvolvida a ativação de casca de coco para máscaras de gases (MARSH et al., 1997).

Não se tem notícia de seu uso em tratamento para abastecimento em menos de 30 anos depois disso quando, finalmente, foi reconhecida sua capacidade de remover diversas sustâncias que dão cheiro, odor e cor (LEHR, 1991).

Segundo Smisek \& Cerny (1970), durante o processo de ativação os espaços entre as camadas cristalizadas tornam-se livres de vários compostos carbonáceos e de cadeias de carbono não-organizadas; os vazios resultantes são denominados poros. Um bom processo de ativação cria um enorme número de poros; assim a área superficial interna do carvão ativado é muito grande e esta é a 
principal razão para sua alta capacidade de adsorção. De acordo com Lehr (1991), a área superficial dos grãos de carvão pode variar entre 500 e 1000 metros quadrados por grama.

Alguns tipos de carvão têm tamanhos dos poros e sua distribuição uniformes, enquanto outros podem ser irregulares. Carvões típicos usados em tratamento de água têm tamanhos dos poros na faixa de 10 a 10000 angstrons. $\mathrm{O}$ tamanho e a forma dos poros determinam o tipo de contaminante que será adsorvido (LEHR, 1991).

A estrutura porosa de um carvão ativado é função da preparação seguida do método de ativação e do tempo de ativação. Esta é a principal razão de a área superficial e o volume dos poros variarem tanto de um carvão para outro (MARSH et al., 1997).

De acordo com Smisek \& Cerny (1970), a estrutura e as propriedades do carvão ativado são parecidas com as do grafite, que é composto de camadas planas formadas por átomos de carbono ordenados em hexágonos regulares, semelhantes àqueles anéis de compostos orgânicos aromáticos. 


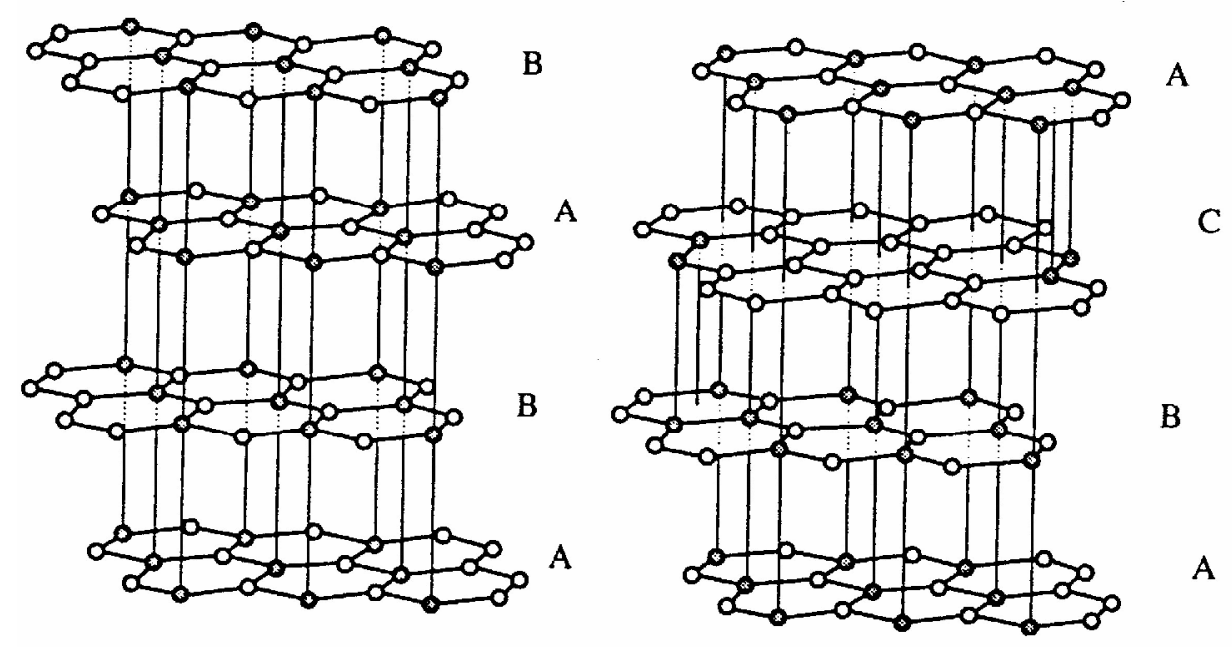

Figura 3.6 - Dois exemplos de estrutura química do grafite.

(FONTE: MARSH et al., 1997).

Basicamente a estrutura do carvão ativado contém poros classificados em três grupos, microporos - tamanho dos poros $<2 \mathrm{~nm}$-, mesoporos - 2 a $50 \mathrm{~nm}$ - e macroporos - > $50 \mathrm{~nm}$. Os microporos usualmente têm cerca de 95\% do total da área superficial de um carvão ativado comum (WU et al., 1999). Os microporos tornam-se preenchidos por soluções aquosas a baixas pressões relativas e são responsáveis pelas mais fortes capacidades de adsorção. Os mesoporos, ou poros transitórios, são preenchidos por ação de capilaridade, e para os macroporos o limite inferior de $50 \mathrm{~nm}$ corresponde ao limite prático do método de determinação de tamanho dos poros (MARSH et al., 1997).

Esses autores afirmam que embora a maior parte da adsorção ocorra nos microporos, meso e macroporos têm importante papel em qualquer processo de adsorção, porque eles servem como passagem para o adsorbato até os microporos, uma vez que poucos destes estão localizados na superfície externa da partícula de carvão. Assim, é compreensível a importância do controle do 
processo de ativação para obtenção de carvões ativados específicos para determinada aplicação.

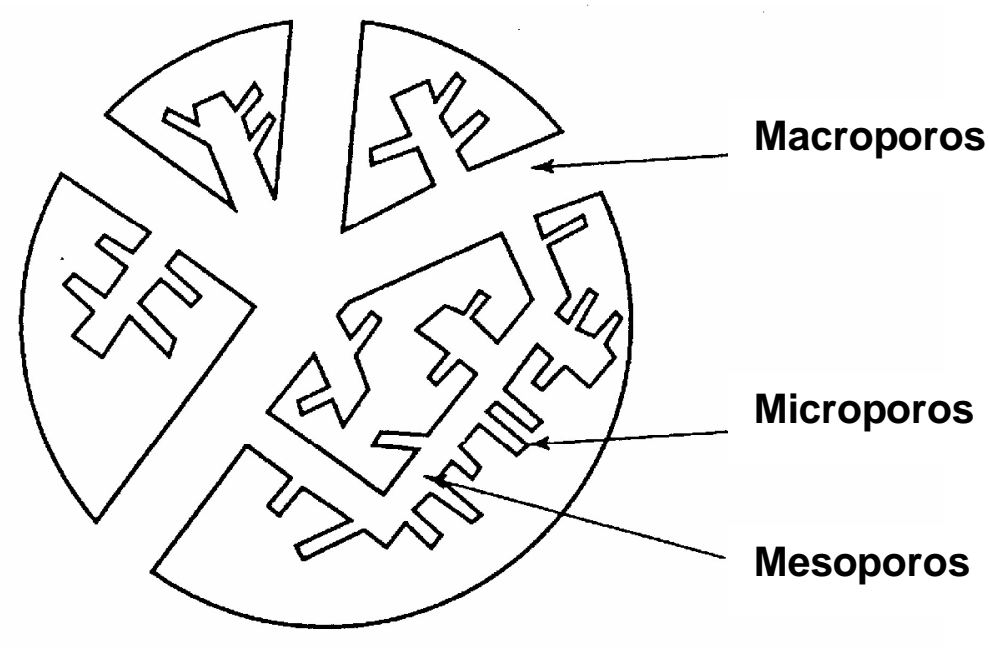

Figura 3.7 - Representação esquemática de um grânulo de carvão ativado. (FONTE: MARSH et al., 1997).

As propriedades de adsorção do carvão ativado são determinadas não apenas pelas estruturas de seus poros, mas também por sua composição química (SMISEK \& CERNY, 1970). Segundo Marsh et al. (1997), a eficiência do carvão ativado depende da acessibilidade na área superficial interna, das forças físicas e também da presença de sítios de adsorção nos quais a adsorção química pode ocorrer.

A superfície do carvão ativado pode adsorver moléculas presentes em gases ou líquidos por forças predominantemente físicas do tipo de Van der Waals, causando maior concentração de adsorbato na interface do que no volume do fluido; contudo pode haver a possibilidade de adsorção química, causada por 
forças de valência, nos chamados sítios de adsorção na superfície do carvão (MARSH et al., 1997). Pendleton et al. (2001) dizem que o pH da solução também afeta a adsorção pelo carvão ativado devido à polarização preferencial do grupo químico da superfície do adsorvente.

Existem alguns métodos para determinação da área superficial e da capacidade de adsorção dos carvões. Dentre estes métodos estão a determinação do número de iodo e o número de azul de metileno. A adsorção do iodo é um teste simples e rápido, que dá uma indicação da área superficial interna; o número de iodo é expresso em mg de iodo por grama de carvão (MARSH et al., 1997).

Barton (1987) diz que a adsorção do corante catiônico, azul de metileno, tem sido usada por longo tempo para avaliação das propriedades do carvão ativado. O procedimento, primeiramente sugerido em 1924, é ainda descrito em normas para uso industrial. Devido à análise simples, a adsorção de azul de metileno de soluções aquosas continua como ferramenta útil para controle da manufatura de carvões ativados. A adsorção de azul de metileno deve ser interpretada como uma medida de áreas de macro e mesoporos. A adsorção de azul de metileno dá uma indicação da capacidade de adsorção de moléculas grandes com dimensões similares às do azul de metileno. O mecanismo de adsorção de corantes pela porosidade de sólidos é característica do corante. A Figura 3.8 mostra a estrutura molecular do azul de metileno. 


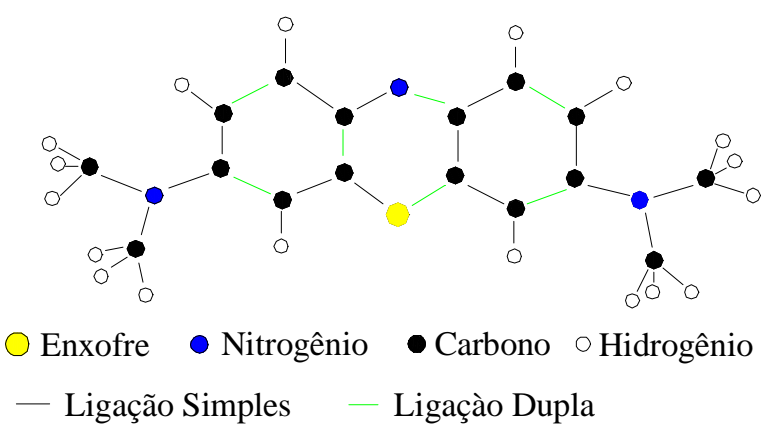

Figura 3.8 - Estrutura molecular do azul de metileno.

(Fonte: IMAMURA et al., 2002).

Outro método utilizado para caracterização do carvão ativado é o uso de isotermas de adsorção. A quantidade de adsorvato que pode ser ligado a um adsorvente - carvão ativado - é função de suas características e da concentração do adsorvato a uma determinada temperatura. As equações usadas que, geralmente, descrevem resultados experimentais, foram desenvolvidadas por alguns pesquisadores, em especial por Freundlich e por Langmuir (METCALF \& EDDY, 2003).

A isoterma desenvolvida empiricamente por Freundlich é definida a seguir:

$$
\frac{x}{m}=k_{f} \cdot C_{e}^{1 / n}
$$

onde: $\mathrm{x} / \mathrm{m}=\mathrm{a}$ quantidade de adsorvato adsorvido por unidade de carvão $\mathrm{C}_{\mathrm{e}}=$ concentração de equilíbrio de adsorvato na solução após a adsorção $\mathrm{K}_{f}, \mathrm{n}=$ constantes empíricas 
As constantes da isoterma de Freundlich podem ser determinadas plotando (x/m) contra C com a equação 3.1 sendo reescrita como:

$$
\log \frac{x}{m}=\log K_{f}+\frac{1}{n} \cdot \log C_{e}
$$

A isoterma de Langmuir foi desenvolvida assumindo que (1) estão disponíveis um número fixo de sítios de adsorção e que as energias de adsorção são iguais e (2) que a adsorção é reversível (METCALF \& EDDY, 2003).

A equação definida por Langmuir é a seguinte:

$$
\frac{x}{m}=\frac{\left(a \cdot b \cdot C_{e}\right)}{\left(1+b \cdot C_{e}\right)}
$$

onde: $\mathrm{x} / \mathrm{m}$ = quantidade adsorvida por unidade de carvão

a, b = constantes empíricas

$\mathrm{C}_{\mathrm{e}}=$ concentração de equilíbrio de adsorvato após a adsorção

As constantes podem ser deteminadas plotanto $\mathrm{C} /(\mathrm{x} / \mathrm{m})$ contra $\mathrm{C}$ com a equação 3.3 sendo reescrita como:

$$
\frac{C_{e}}{(x / m)}=\frac{1}{a \cdot b}+\frac{1}{a} \cdot C_{e}
$$

De acordo com Wu et al. (1999) as isotermas de adsorção são importantes para descrever como os adsorvatos interagem com os adsorventes e para otimizar o uso de adsorventes.

Os carvões ativados usuais não são hábeis em adsorver seletivamente moléculas de diferentes dimensões (MARSH et al., 1997). Quanto maior a área de 
uma molécula, maior a energia de ligação; como resultado tem-se moléculas maiores mais fortemente adsorvidas que as menores (LEHR, 1991).

Como já mencionado, a microcistina é um heptapeptídeo cíclico. Geralmente, em soluções aquosas, os peptídeos exibem propriedades hidrofóbicas; isso sugere que a interação primária entre a microcistina e o carvão ativado é feita via hidrofobicidade ou forças de dispersão (PENDLETON et al., 2001).

Quanto maior a concentração de contaminante maior sua chance de ser adsorvido. Enquanto a concentração reduz, a capacidade do contaminante permanecer na solução aumenta. Por razões semelhantes, baseados em forças atrativas, é fácil entender que moléculas orgânicas menos solúveis adsorvam mais facilmente enquanto as mais solúveis adsorvam menos (LEHR, 1991).

Lanaras $^{3}$ et al. apud PENDLETON et al. (2001) relataram que a microcistina em solução tem volume de $2,6 \mathrm{~nm}^{3}$, área de $1,8 \mathrm{~nm}^{2}$ e comprimento molecular de 1,9 nm. Donati ${ }^{4}$ et al., também citados por Pendelton et al. (2001), investigaram a taxa e a efetividade de adsorção de microcistina por vários diferentes carvões ativados em pó e apresentaram sua remoção como diretamente proporcional ao volume de mesoporos do adsorvente. Considerando as dimensões da microcistina essa informação não é surpresa.

Geralmente para moléculas de peso molecular maior, sua solubilidade na água diminui e a adsorção do carvão aumenta. Muito matérial orgânico é mais

\footnotetext{
${ }^{3}$ LANARAS, T.; COOK, C. M.; ERIKSSON, J. E.; MERILUOTO, J. A. O. \& HOTOKKA, M. (1991). Toxicon 29, 901.

${ }^{4}$ DONATI, C.; DRIKAS, M.; HAYES, R. \& NEWCOMBE, G. (1994). Water Research 28, 1735.
} 
solúvel em soluções alcalinas ou básicas do que em soluções ácidas. Igualmente baixas temperaturas promovem adsorção enquanto altas temperaturas promovem dessorção (LEHR, 1991).

Os carvões a base de madeira contêm microporos e mesoporos; os carvões a base de casca de coco contêm apenas microporos. Carvões de madeira adsorvem mais microcistina do que carvões de côco (PENDLETON et al., 2001).

É bem conhecido que as bactérias podem ser adsorvidas em carvão ativado granular. Porém uma vez adsorvidas, as bactérias podem multiplicar-se e produzir colônias que podem ser arrastadas pelo fluxo de água. Para prevenir essa ocorrência, às vezes o carvão ativado é impregnado com prata, que serve como um bactericida (LEHR, 1991). 


\section{4 - MATERIAIS E MÉTODOS}

\section{1 - Considerações Iniciais}

O presente estudo foi dividido em três etapas cada uma dividida em fases.

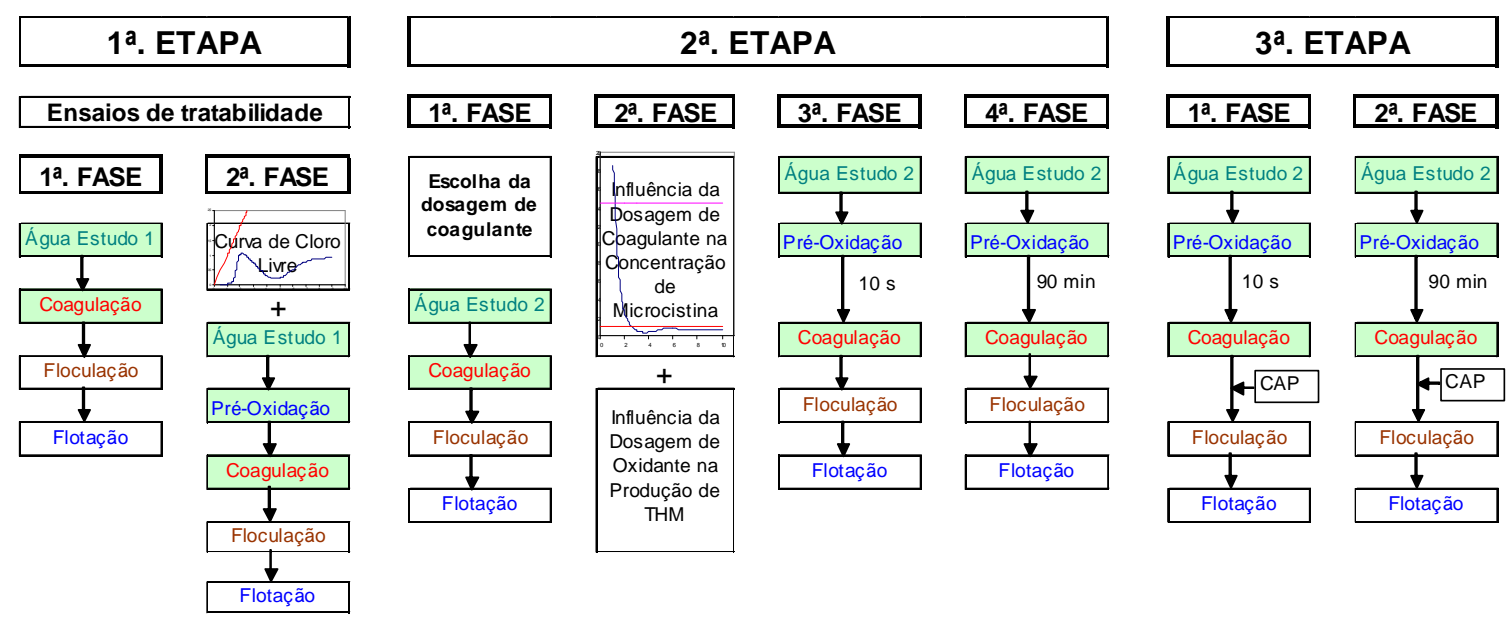

Figura 4.1 - Esquema simplificado dos ensaios

Para a primeira etapa foi preparada uma água de estudo e para as demais etapas foi preparada outra água.

A primeira etapa constituiu em ensaios de tratabilidade da água com e sem pré-oxidação. Na primeira fase foram realizados ensaios de flotação por ar 
dissolvido precedidos de coagulação/floculação. $\mathrm{Na}$ segunda fase foram realizados ensaios para obtenção de uma curva de cloro residual livre em função da dosagem de hipoclorito de sódio, para escolha das dosagens de oxidante a serem estudadas, e foram feitos ensaios de coagulação/floculação e flotação precedidos por pré-oxidação.

A segunda etapa foi dividida em quatro fases: na primeira foram feitos ensaios simplificados de tratabilidade, pois foi preparada uma água diferente daquela usada na primeira etapa. Na segunda fase foram investigadas a influência da dosagem de oxidante na remoção de microcistina e a produção de trihalometanos. Na terceira fase foi estudada a aplicação de oxidante 10 segundos antes da coagulação e na quarta fase o tempo de contato do oxidante antes da coagulação foi 90 minutos.

A terceira etapa foi constituída de duas fases, ambas com aplicação de carvão ativado em pó logo após a coagulação; na primeira fase o tempo de contato do oxidante foi 10 segundos e na segunda, 90 minutos.

\section{2 - Água de Estudo}

\subsection{1 - Características do Local de Coleta}

A água bruta foi preparada com água proveniente do reservatório de Barra Bonita, localizado no interior do Estado de São Paulo e pertencente à Bacia do Rio Tietê Médio Superior. A bacia hidrográfica onde se encontra o citado reservatório 
é caracterizada pela presença de áreas urbanas nas quais se concentram mais de 400.000 habitantes, além de áreas agrícolas, com cultura de cana-de-açúcar, café, hortaliças, laranja e outras frutas; pastagens cultivadas e naturais; atividades industriais com produção de têxteis, alimentos, papel, abatedouro, engenhos e uma usina de açúcar e álcool. Os dois formadores do reservatório são os rios Tietê e Piracicaba que exercem profunda influência na qualidade de suas águas.

Resultados de um levantamento sazonal efetuado por Calijuri (1999) indicam que o reservatório de Barra Bonita apresenta nível eutrófico ao longo do ano com contagem de algas da ordem de $10^{6}$ organismos $/ \mathrm{mL}$. Em termos físicoquímicos, o referido estudo indica que as águas do reservatório apresentam padrão estável, tendo em vista suas características hidrodinâmicas que favorecem constante mistura de suas águas.

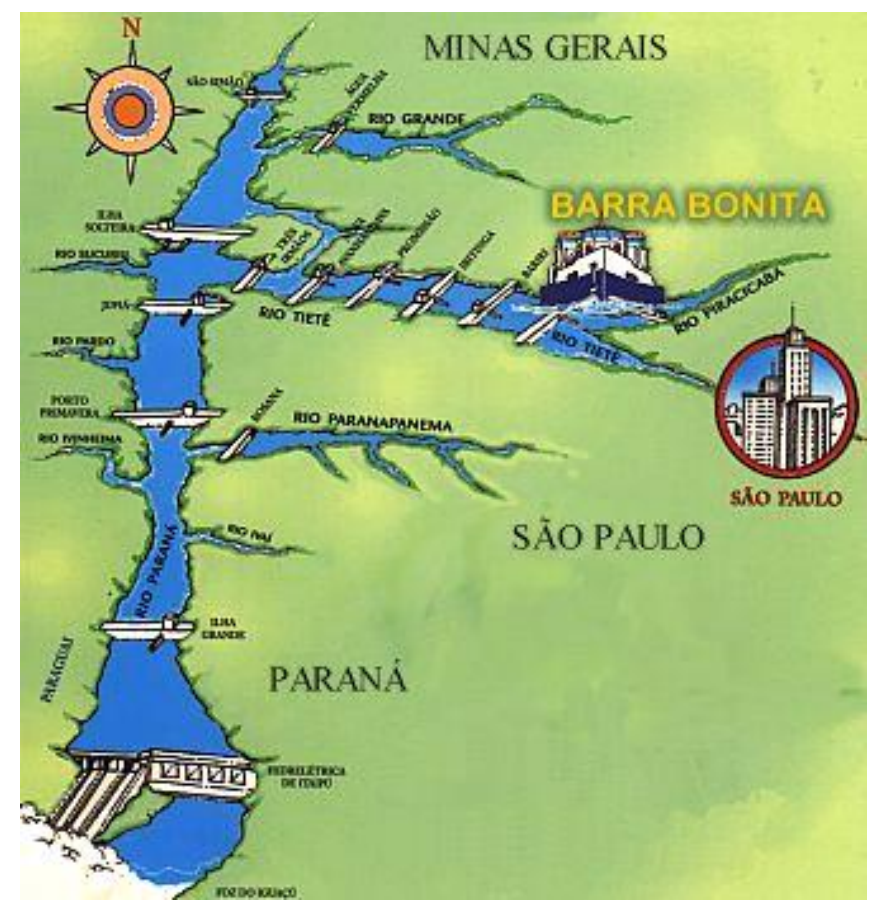

Figura 4.2 - Esquema localizando o reservatório de Barra Bonita no interior do Estado de São Paulo. 


\subsection{2 - Coleta e Preparo da Água de Estudo}

Em princípio, a coleta de amostras no resenatório estava programada para ser feita de acordo com o processo de amostragem em função das características do dia da coleta e as determinações de concentrações de cianobactérias e toxinas - nesse caso a microcistina - seriam as presentes na água do reservatório. Porém depois de algumas coletas foram identificados alguns problemas. Como o reservatório é um ecossistema eutrófico, pode apresentar floração de organismos fitoplanctônicos com presença de cianobactérias, e pelo fato do ponto de coleta principal ficar ao lado da barragem - ponto A da Figura 4.3 -em alguns dias de coleta foi encontrada concentração de "nata" de organismos fitoplanctônicos provocada pelo vento e pelo movimento das águas. Esse fato prejudicou a coleta e, devido à elevada concentração de organismos, piorou a qualidade da água que seria levada ao laboratório.

Quando, no local de coleta, a água apresentava essas características, com o objetivo de coletar uma amostra com menor concentração de microrganismos, a coleta foi feita em local mais distante da barragem onde há uma pequena península - ponto B da Figura 4.3. Nesse local, realmente, a concentração de florações geralmente era menor que a do local de coleta principal. Em dias muito quentes e sem presença de ventos, as extensas florações cobriam uma área muito grande do reservatório. Nesses dias as coletas foram realizadas com auxílio de uma canalização por onde passa água bombeada do reservatório para alimentar os tanques de piscicultura operados pela empresa responsável pelo reservatório - ponto C da Figura 4.3. Essa canalização capta a água alguns 
metros abaixo da superfície e, assim, não possui grandes concentrações de colônias de cianobactérias. Quando a amostra era coletada nessa canalização, também era tirada uma parcela de água do ponto principal e feita uma amostra mista de ambas as amostras com o intuito de garantir uma concentração suficiente grande de colônias para estudo. A Figura 4.3 mostra fotos dos locais de coleta.

Mesmo com esse procedimento de coleta para atenuar os efeitos dessas possíveis florações, foi encontrado outro problema. A concentração de microcistina da água do reservatório era muito baixa, principalmente da amostra coletada na canalização, já que a concentração de cianobactérias nessa água era muito menor do que a da superfície.
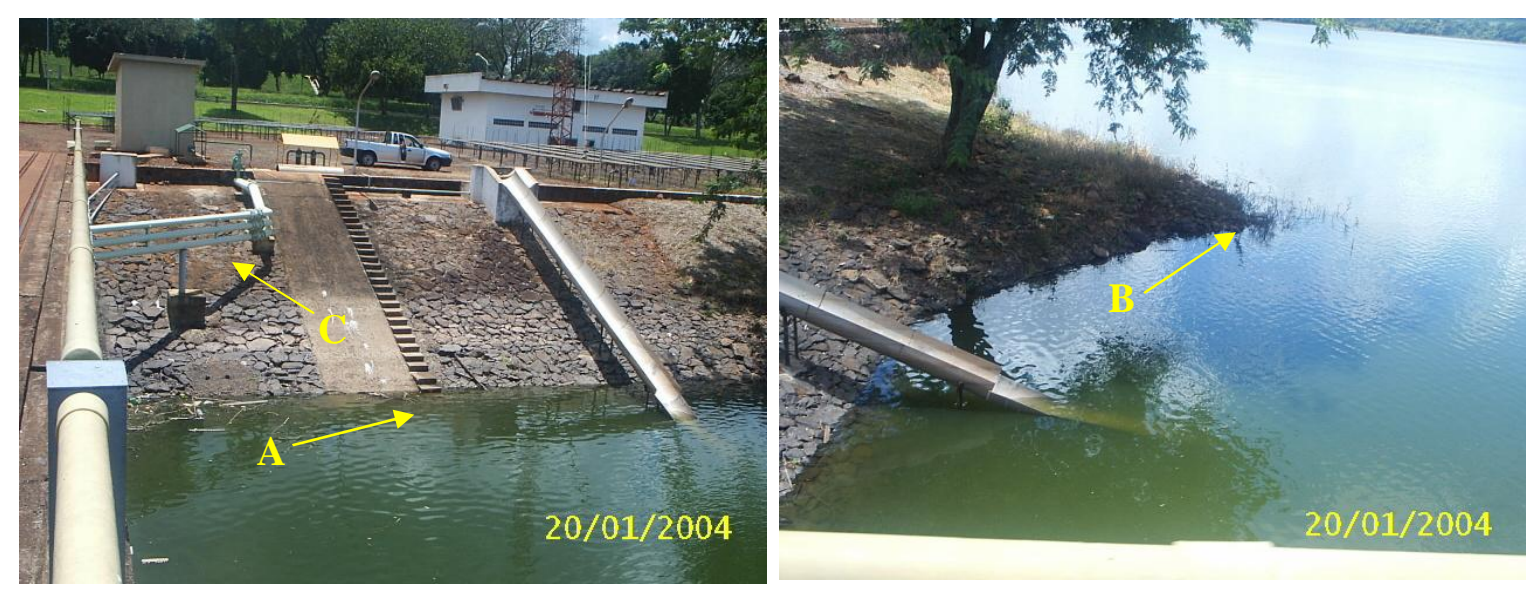

Figura 4.3 - Fotos do ponto de coleta no reservatório de Barra Bonita.

Como a proposta de estudo envolvia justamente a remoção de microcistina a concentração dessa toxina encontrada no reservatório - máximo valor encontrado: $2,5 \mu \mathrm{g} / \mathrm{L}$ - não foi condizente para o estudo. 
Sabe-se que a microcistina pode ser encontrada tanto na forma extracelular - dissolvida no meio - como na forma intracelular - no interior das células. A toxina é liberada pelas células em situações de estresse, lise celular e também na fase de senescência, por esse motivo buscou-se sonizar o meio para causar a lise celular, usando um aparelho de ultra-som - marca Unique UltraSonic, tipo Disruptor de Célula - como feito por Ferreira (2004). Foi sonizado durante 10 minutos 1 litro da "nata" celular coletada no reservatório e essa alíquota foi misturada na água coletada no reservatório. Esse método provocou a ruptura celular e embora eficiente na liberação de toxina pela célula, também foram liberados pigmentos intracelulares causando cor e turbidez elevadas na água de estudo.

Dada a dificuldade de obter-se uma concentração adequada de organismos somada ao problema de baixa concentração de cianotoxina e aos elevados valores de cor e turbidez causados pela sonização da "nata" celular, optou-se por preparar uma cultura de cianobactérias.

\subsection{3 - Cultura de Cianobactérias}

A cultura foi preparada nas instalações construídas para esse fim junto ao Laboratório Avançado de Tratamento de Águas para Reúso (LATAR) do Departamento de Hidráulica e Saneamento da Escola de Engenharia de São Carlos a partir de cepa de cianobactérias do gênero Microcystis comprovadamente tóxica fornecida pelo Prof ${ }^{\circ}$. Dr. Armando Augusto H. Vieira do Departamento de Botânica da Universidade Federal de São Carlos - código da cepa: BB-005. 
A cultura foi preparada com base no trabalho de Tavares e Rocha (2003) que indica algumas condições para o cultivo como: duração do fotoperíodo de 12 horas de escuro por 12 horas de luz controlada por dispositivo eletrônico; luminosidade a partir de lâmpadas brancas fluorescentes; temperatura entre 15 e $25^{\circ} \mathrm{C}$ - no caso da instalação do LATAR o controle da temperatura é feito com o auxílio de um climatizador mantendo-a a $20 \pm 1{ }^{\circ} \mathrm{C}$-; aeração com bombas de aquário e; $\mathrm{pH}$ do meio de cultura preparado entre 7,0 e 8,0 corrigido com $\mathrm{NaOH}$.

O meio de cultura usado foi o descrito por Gorham¹ (1964) apud. LORENZI (2004) denominado ASM-1 que contém a formulação apresentada na Tabela 4.1.

A vidraria utilizada era de uso exclusivo para o cultivo e antes de ser usada era tratada em solução de detergente neutro e, em seguida, com ácido clorídrico 10\%. Após passar pela solução de ácido, a vidraria era repetidamente enxaguada em água de torneira e, finalmente, em água destilada.

A esterilização do meio de cultura era feita em autoclave à $120^{\circ} \mathrm{C}$ por 20 minutos, e a da vidraria em câmara de UV com comprimento de onda da ordem de $254 \mathrm{~nm}$.

Para preparar a água de estudo a cultura desenvolvida em laboratório foi diluída à água coletada na canalização de captação de água do reservatório de Barra Bonita, em proporção tal que a água de estudo tivesse concentração de microcistina da ordem de $15 \mu \mathrm{g} / \mathrm{L}$.

\footnotetext{
${ }^{1}$ GORHAM, P. R.; MCLACHLAN, J. R.; HAMMER, V. T. \& KIM, W. K. (1964). Isolation and Culture of Toxic Strains of Anabaena flos-aquae. Verhandlungen - Internationale Vereinigung fur Theoretisce und Angewandte Limnologie, v.15, p. 796-804.
} 
Tabela 4.1 - Composição do meio de cultura ASM-1

\begin{tabular}{lc|lc}
\hline \multicolumn{1}{c|}{ Nutriente } & $\begin{array}{c}\text { Concentração } \\
(\mathbf{m g} / \mathbf{L})\end{array}$ & \multicolumn{1}{|c}{ Nutriente } & $\begin{array}{c}\text { Concentração } \\
\text { (mg/ } \mathbf{l})\end{array}$ \\
\hline $\mathrm{NaNO}_{3}$ & 170 & $\mathrm{H}_{3} \mathrm{BO}_{3}$ & 2,48 \\
$\mathrm{MgSO}_{4} \cdot 7 \mathrm{H}_{2} \mathrm{O}$ & 49 & $\mathrm{MnCl}_{2} 4 \mathrm{H}_{2} \mathrm{O}$ & 1,39 \\
$\mathrm{MgCl}_{2} \cdot 7 \mathrm{H}_{2} \mathrm{O}$ & 41 & $\mathrm{FeCl}_{3} \cdot 6 \mathrm{H}_{2} \mathrm{O}$ & 1,08 \\
$\mathrm{CaCl}_{2} \cdot 2 \mathrm{H}_{2} \mathrm{O}(\mathrm{ou})$ & 29 & $\mathrm{ZnCl}_{2}$ & 0,335 \\
$\mathrm{CaCl}_{2}$ anidro & 21,9 & $\mathrm{CoCl}_{2} \cdot 6 \mathrm{H}_{2} \mathrm{O}$ & 0,019 \\
$\mathrm{KH}_{2} \mathrm{PO}_{4}(\mathrm{ou})$ & 17,4 & $\mathrm{CuCl}_{2} \cdot 2 \mathrm{H}_{2} \mathrm{O}$ & 0,0014 \\
$\mathrm{KH}_{2} \mathrm{PO}_{4} \cdot 3 \mathrm{H}_{2} \mathrm{O}$ & 22,8 & EDTA.Na & 7,44 \\
$\mathrm{NaHPO}_{4} \cdot 12 \mathrm{H}_{2} \mathrm{O}$ & 35,6 & & \\
\hline
\end{tabular}

A água bruta coletada e a água de estudo eram conservadas no laboratório em câmara fria com temperatura em torno de $4{ }^{\circ} \mathrm{C}$ por período máximo de 6 dias.

\subsection{4 - Caracterização das Águas de Estudo}

Para caracterização da água de estudo foram determinados os seguintes parâmetros: cor, turbidez, pH, sólidos totais (ST), sólidos suspensos totais, demanda química de oxigênio (DQO), nitrogênio total (NTK), nitrogênio amoniacal, fósforo, absorbância em 254 nm, alcalinidade, contagem de algas, clorofila-a e microcistina.

As determinações foram feitas usando equipamentos e instalações do LATAR, exceto a contagens de algas que foi realizada no Laboratório de Biotoxicologia de Águas Continentais e Efluentes (BIOTACE) também da EESC/USP. As metodologias para as determinações foram as definidas pelo Standards Methods for the Examination of Water and Wastewater $20^{a}$ edição 
(1998), exceto clorofila-a e microcistina as quais são descritas em itens posteriores.

Como os ensaios requeriam grandes volumes de água, não foi possível fazê-los todos com água de uma mesma coleta, por dois motivos: dificuldade de transporte de maiores volumes do reservatório até o laboratório e temor que o tempo de armazenagem da água possibilitasse a mudança de suas características. Por isso foram feitas duas campanhas de coleta e preparo da água de estudo, e obtidas assim a Água de Estudo 1 e Água de Estudo 2.

\section{Caracterização da Água de Estudo 1}

A água de estudo foi preparada de tal modo que a adição da cultura na água do reservatório proporcionasse concentração de microcistina na água de estudo de cerca de $15 \mathrm{mg} / \mathrm{L}$. Foram medidas as concentrações de microcistina da água do reservatório e da cultura e obtidos os resultados de, respectivamente, $0,15 \mu \mathrm{g} / \mathrm{L}$ e $234 \mu \mathrm{g} / \mathrm{L}$. Assim 6,5 litros de cultura foram misturados a 93,5 litros da água do reservatório, portanto a concentração de microcistina da água de estudo era da ordem de 15,6 $\mu \mathrm{g} / \mathrm{L}$. Com essa mistura as características da água de estudo foram as apresentadas na Tabela 5.1, mostrada no próximo capítulo, junto com algumas características da água do reservatório e da cultura.

\section{Caracterização da Água de Estudo 2}

Para o preparo da água de estudo 2 foram necessários 4,2 litros de cultura e 95,8 litros da água do reservatório, pois as concentrações de microcistina eram 
de, respectivamente, $350 \mu \mathrm{g} / \mathrm{L}$ e $0,2 \mu \mathrm{g} / \mathrm{L}$. O resultado de microcistina para a água de estudo foi de $14,45 \mu \mathrm{g} / \mathrm{L}$. Também foi feita a contagem de organismos para a água de estudo 2, da água do reservatório e da cultura de cianobactérias. Os resultados da caracterização da água de estudo 2 e da contagem de organismos estão apresentados no capítulo 5, Tabela 5.2 e Figura 5.1.

\section{3 - Procedimento Adotados nos Ensaios}

Nesse item são descritos os procedimentos adotados nos ensaios e as etapas que fizeram parte da pesquisa. O coagulante utilizado em todos os ensaios foi o Cloreto Férrico $\left(\mathrm{FeCl}_{3}\right)$. Uma solução de $20 \mathrm{~g} / \mathrm{L}$ desse sal foi preparada com intuito de a cada $1 \mathrm{~mL}$ dosado em 2 litros de água de estudo resultar uma dosagem de $10 \mathrm{mg} / \mathrm{L}$ de coagulante. Os parâmetros fixados para todos os ensaios foram: tempo de mistura rápida, gradiente médio de velocidade de mistura rápida, tempo de floculação, gradiente médio de velocidade de floculação, pressão relativa no interior da câmara de saturação, tempo de saturação e taxa de recirculação de água saturada. O monitoramento foi feito com leituras de cor aparente e turbidez. Quando utilizado hipoclorito de sódio, depois de feitas as coletas de amostras, era adicionada solução de tiossulfato de sódio para parar a reação do cloro com a água. 


\subsection{1 - Primeira Etapa}

\section{Primeira Fase da Primeira Etapa}

A primeira etapa foi dividida em duas fases (Figura 4.4). Na primeira fase foi feito o ensaio de tratabilidade da água de estudo 1. Nessa fase variou-se a dosagem de coagulante e o pH de coagulação. Foram testadas onze dosagens de coagulante $-15,20,25,30,35,35,40,45,50,55$ e 60 mg/L. Para a dosagem de $15 \mathrm{mg} / \mathrm{L}$ foi testado apenas um $\mathrm{pH}$ de coagulação, para as dosagens de 20 a 45 $\mathrm{mg} / \mathrm{L}$ foram testados seis valores de $\mathrm{pH}$ e para as dosagens de 50 a $60 \mathrm{mg} / \mathrm{L}, 5$ valores de $\mathrm{pH}$. Para variar o pH de coagulação foi preparada uma solução de ácido sulfúrico com concentração $1 \mathrm{~N}$ e também uma solução de barrilha com concentração $10 \mathrm{~g} / \mathrm{L}$. Esses ensaios tiveram como objetivo conhecer-se o comportamento da água de estudo em questão, em relação ao pH e à dosagem de coagulante. Foram coletadas amostras de água flotada em duas velocidades de flotação: $\bigvee_{\text {flot } 1}=26 \mathrm{~cm} / \mathrm{min}\left(\right.$ ou $15,6 \mathrm{~m} / \mathrm{h}$ ) e $\bigvee_{\text {flot2 }}=13 \mathrm{~cm} / \mathrm{min}($ ou $7,8 \mathrm{~m} / \mathrm{h}$ ). 


\section{PRIMEIRA ETAPA}
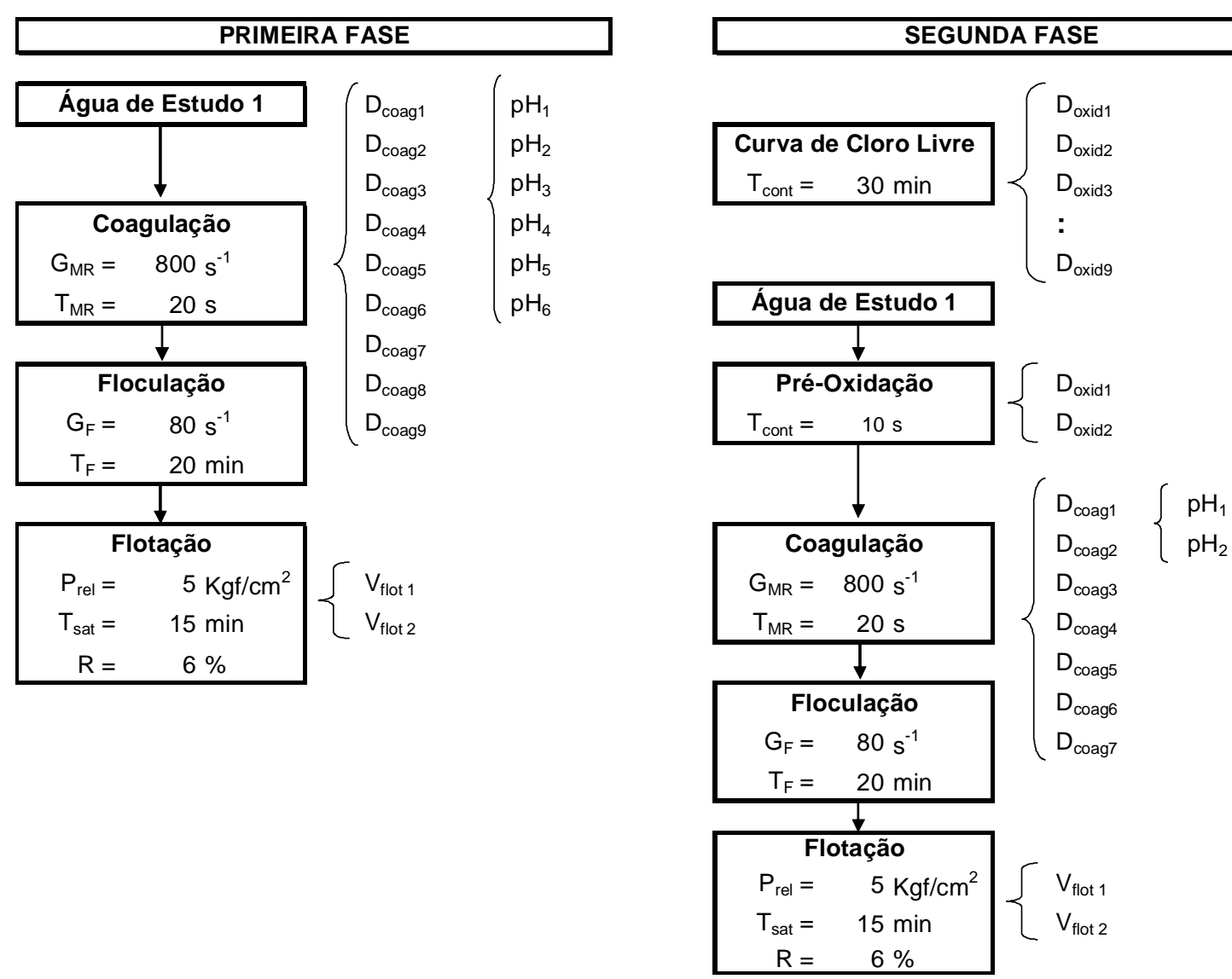

Figura 4.4 - Detalhamento dos Ensaios da Primeira Etapa do Estudo

\section{Segunda Fase da Primeira Etapa}

Para realizar a segunda fase foi necessário conhecer-se o comportamento da água para diversas dosagens do oxidante estudado. Como oxidante foi escolhido o Hipoclorito de Sódio. Por ser muito instável, a cada dia em que foram efetuados os ensaios era preparada uma nova solução. A solução era preparada 
com auxílio do kit comercial de determinação de cloro residual livre da $\mathrm{HACH}-$ código 25020-25. Foi preparada uma solução desse sal de modo que $1 \mathrm{~mL}$ dessa solução em 1 litro de água de estudo resultasse uma dosagem de $1 \mathrm{mg} / \mathrm{L}$ de hipoclorito de sódio.

Foram utilizados duas diferentes dosagens de pré-oxidante e também dois pontos de aplicação (estudados em etapas posteriores); um para simular a aplicação do oxidante na captação de água bruta e o outro logo antes da coagulação. O tempo de contato do oxidante antes da coagulação foi assim variado: para a primeira situação, ponto de captação, o tempo de contato foi de 90 minutos e para a segunda, logo antes da coagulação, 10 segundos.

\section{- Curva de Cloro Livre}

A curva de cloro livre mostra o comportamento da água de estudo para diferentes dosagens de oxidante e serviu como base para escolher as dosagens de oxidante e serem aplicadas no tratamento. A curva foi construída com 9 pontos, ou seja, com nove diferentes dosagens de hipoclorito de sódio. O tempo de contato do oxidante foi 30 minutos, escolhido por ser o tempo médio de cada ensaio a partir da coagulação até a coleta de água flotada. O cloro livre foi medido com auxílio do kit de determinação de cloro livre anteriormente citado. Essa curva é mostrada no capítulo 5 (Figura 5.9).

Escolhidas as dosagens de oxidantes a serem estudadas - 2,1 e 6,0 mg/L teve início o ensaio de tratabilidade, desta vez feito de maneira mais simples. 
Foram variados apenas dois valores de $\mathrm{pH}$ para as sete dosagens de coagulante estudadas para as duas dosagens de oxidante citadas.

\subsection{2 - Segunda Etapa}

A segunda etapa teve como objetivo estudar a aplicação de pré-oxidação para o tratamento de água contendo cianobactérias e microcistina e verificar a influência da aplicação de oxidante na produção de trihalometanos. Foram investigados dois modos de aplicação de oxidante: i) 10 segundos antes da mistura rápida do coagulante e, ii) 90 minutos antes da mistura rápida do coagulante - simulação da situação em que a pré-oxidação seja realizada numa hipotética captação situada distante o suficiente da estação de tratamento de água para que resultasse em tempo de contato do cloro na adutora em torno de 90 minutos.

\section{Primeira Fase da Segunda Etapa}

Como dito anteriormente, a água de estudo para a segunda e terceira etapas do estudo foi diferente da utilizada na primeira etapa. Assim foi necessário determinar as dosagens mais adequadas a serem utilizadas nos demais ensaios. Variaram-se, então, quatro dosagens de coagulante, escolhidas com base em uma faixa de melhores resultados da primeira etapa a saber: 40, 45, 50 e $55 \mathrm{mg} / \mathrm{L}$. Os parâmetros de mistura rápida, floculação e flotação foram fixos e são apresentados na Figura 4.5; foram coletadas amostras em tempos correspondentes a duas velocidades de flotação $\left(\bigvee_{\text {flot1 }}=15,6 \mathrm{~m} / \mathrm{h}\right.$ e $\left.\bigvee_{\text {flot2 }}=7,8 \mathrm{~m} / \mathrm{h}\right)$. 
O monitoramento foi feito com leituras de cor aparente e turbidez; para o melhor resultado foi feita caracterização com sólidos totais, sólidos suspensos totais, DQO, microcistina e clorofila-a. Nessa fase não foi aplicado oxidante.

\section{Segunda Fase da Segunda Etapa}

Na segunda fase da segunda etapa foram estudadas as influências das diferentes dosagens de oxidante na concentração residual de microcistina e na produção de trihalometanos. A solução de hipoclorito de sódio foi preparada como descrita no ítem anterior. Em relação à microcistina foram usadas quatro dosagens de oxidante; 1,0, 2,1, 6,0 e 10,0 mg/L e o tempo de contato do oxidante com a água de estudo foi de 30 minutos. Já para os trihalometanos as quatro dosagens estudadas foram 2,0, 3,0, 4,0 e 5,0 mg/L.

\section{Terceira Fase da Segunda Etapa}

Na primeira etapa de estudo verificou-se que para uma mesma dosagem de coagulante, qualquer que fosse a quantidade de oxidante aplicada, piorava levemente a qualidade do efluente do tratamento. Assim com base nas dosagens estudadas na primeira fase desta segunda etapa foram escolhidas as dosagens de coagulante de 45 e $50 \mathrm{mg} / \mathrm{L}$. A de $45 \mathrm{mg} / \mathrm{L}$ por ter sido a que apresentou melhor resultado e a de $50 \mathrm{mg} / \mathrm{L}$ devido à piora branda quando se dosava o oxidante. As dosagens de oxidante estudadas, novamente, foram, 2,1 e 6,0 mg/L, aplicadas sempre 10 segundos antes da coagulação. Os parâmetros de coagulação, floculação e flotação fixos, foram os mesmos nos ensaios anteriores. 
O monitoramento foi feito com determinações de cor aparente, turbidez, absorbância a 264 nm, DQO, clorofila-a, microcistina e trihalometanos.

\section{Quarta Fase da Segunda Etapa}

Para quarta fase, em relação à terceira, foi alterado o tempo de aplicação do oxidante antes da coagulação, foi fixa a dosagem de coagulante, escolhida com base no melhor resultado da terceira etapa e foi usada apenas uma velocidade de flotação $\left(\bigvee_{\text {flot }}=13 \mathrm{~cm} / \mathrm{min}\right.$ ou $\left.\bigvee_{\text {flot }}=7,8 \mathrm{~m} / \mathrm{h}\right)$. Para simular uma aplicação no ponto de captação de água bruta o oxidante foi aplicado 90 minutos antes do processo de coagulação com agitação - descrita no item 4.4.1. Foi coletada uma amostra apenas para velocidade de flotação de $13 \mathrm{~cm} / \mathrm{min}$ devido ao fato de o ensaio ser demorado, o que impossibilita na réplica do ensaio, e era necessário coletar um volume grande de amostra para realizar a caracterização do efluente. Caso fosse feita a coleta na outra velocidade de flotação o volume possível de coleta cairia consideravelmente. Então optou-se por fazer a coleta em apenas uma velocidade. 


\section{SEGUNDA ETAPA}

\section{PRIMEIRA FASE}

\section{Água de Estudo 2}

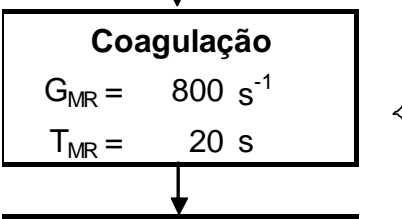

Floculação

$\mathrm{G}_{\mathrm{F}}=80 \mathrm{~s}^{-1}$

$\mathrm{T}_{\mathrm{F}}=20 \mathrm{~min}$

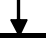

Flotação

$P_{\text {rel }}=5 \mathrm{Kgf} / \mathrm{cm}^{2}$

$\mathrm{T}_{\mathrm{sat}}=15 \mathrm{~min}$

$\mathrm{R}=6 \%$

\section{SEGUNDA FASE}

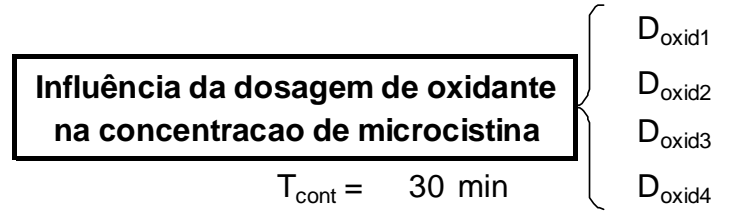

Influência da dosagem de oxidante

$D_{\text {oxid1 }}$

$D_{\text {oxid2 }}$

na concentracao de trihalometanos

$\mathrm{T}_{\text {cont } 1}=20 \mathrm{~min}$

$\mathrm{D}_{\text {oxid3 }}$

$\mathrm{T}_{\text {cont2 }}=24 \mathrm{~h}$

\section{TERCEIRA FASE}

\section{Água de Estudo 2}

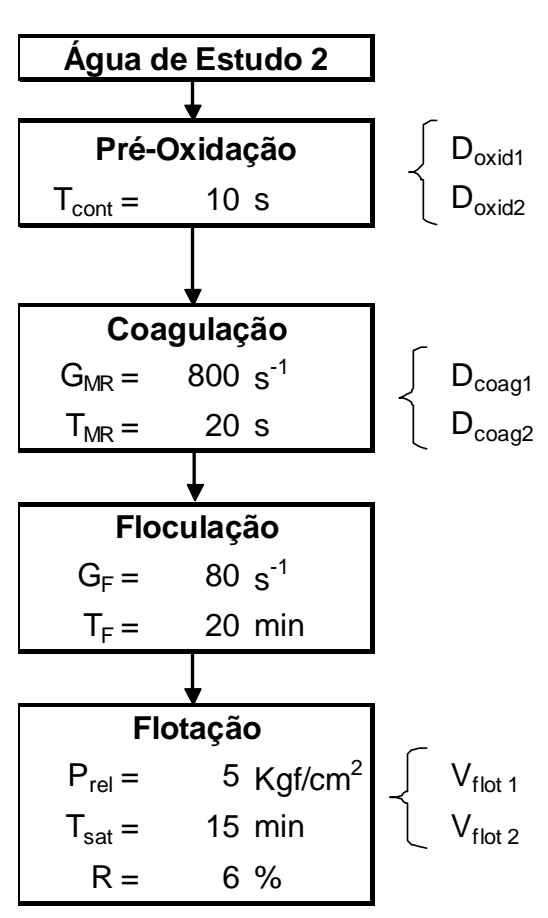

\section{QUARTAFASE}

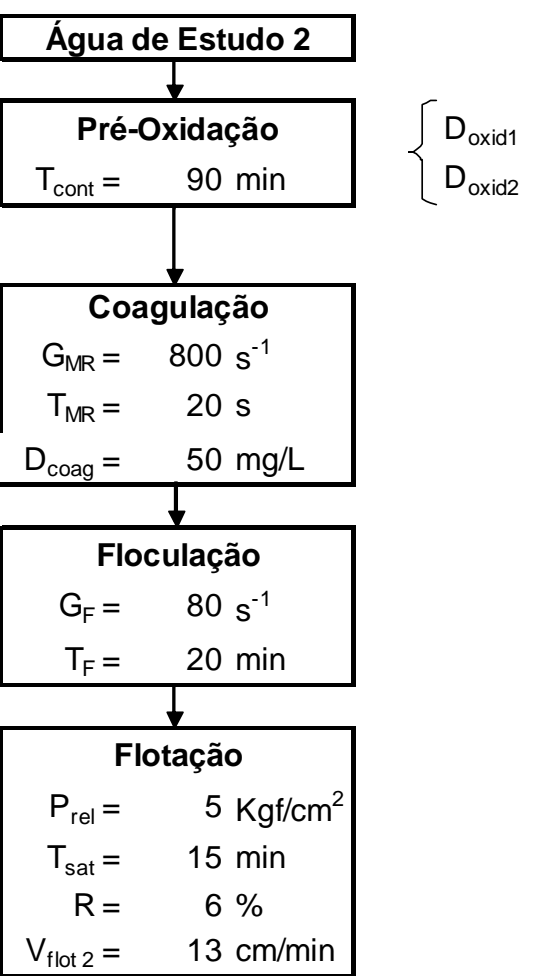

Figura 4.5 - Detalhamento dos ensaios da Segunda Etapa 


\subsection{3 - Terceira Etapa}

Nesta etapa de estudo foi estudada a aplicação de carvão ativado em pó (CAP) com a finalidade de verificar a eficiência da associação oxidação/carvão. Para os ensaios com carvão ativado foram solicitadas amostras de carvão de alguns representantes comerciais de fábricas de carvão ativado. Foram recebidas sete amostras diferentes, as quais foram submetidas às análises. Para todos os carvões foram determinados o número de iodo e o número de azul de metileno (Tabela 4.2). Para o carvão que apresentou o melhor par para esses valores foram feitos ensaios para realização de isotermas de adsorção. Essa caracterização do carvão foi feita pelo mestrando $\mathrm{Eng}^{\circ}$ André Luis Vieira da Silva em trabalho ainda não publicado. O carvão marcado na cor azul na Tabela 4.2 é o que apresentou os melhores resultados e o carvão marcado em vermelho os piores no geral.

Tabela 4.2 - Caracterização dos carvões ativados em pó testados em relação ao número de iodo e número de azul de metileno.

\begin{tabular}{lcc}
\hline Carvão & $\begin{array}{c}\text { Número de } \\
\text { lodo } \mathbf{( m g / g )}\end{array}$ & $\begin{array}{c}\text { Número de Azul } \\
\text { de Metileno } \\
\text { (mg/g) }\end{array}$ \\
\hline Carvão 1 & 793 & 202 \\
Carvão 2 & 753 & 201 \\
Carvão 3 & 972 & 441 \\
Carvão 4 & 907 & 349 \\
Carvão 5 & 717 & 162 \\
Carvão 6 & 642 & 300 \\
Carvão 7 & 940 & 281 \\
\hline
\end{tabular}

Para o carvão 3 foram feitas as isotermas de adsorção de Lagmuir e de Freudlich apresentadas na Figura 4.6. Com base nessas isotermas foi escolhida a 
dosagem de carvão ativado em pó utilizadas nos ensaios subseqüentes. A dosagem de $20 \mathrm{mg} / \mathrm{L}$ é maior do que a necessária segundo a equação de Freundlich. Optou-se por ligeira sobredosagem tendo em vista a competição por sítios de adsorção que outras substâncias orgânicas apresentam em relação à microcistina presente na água.
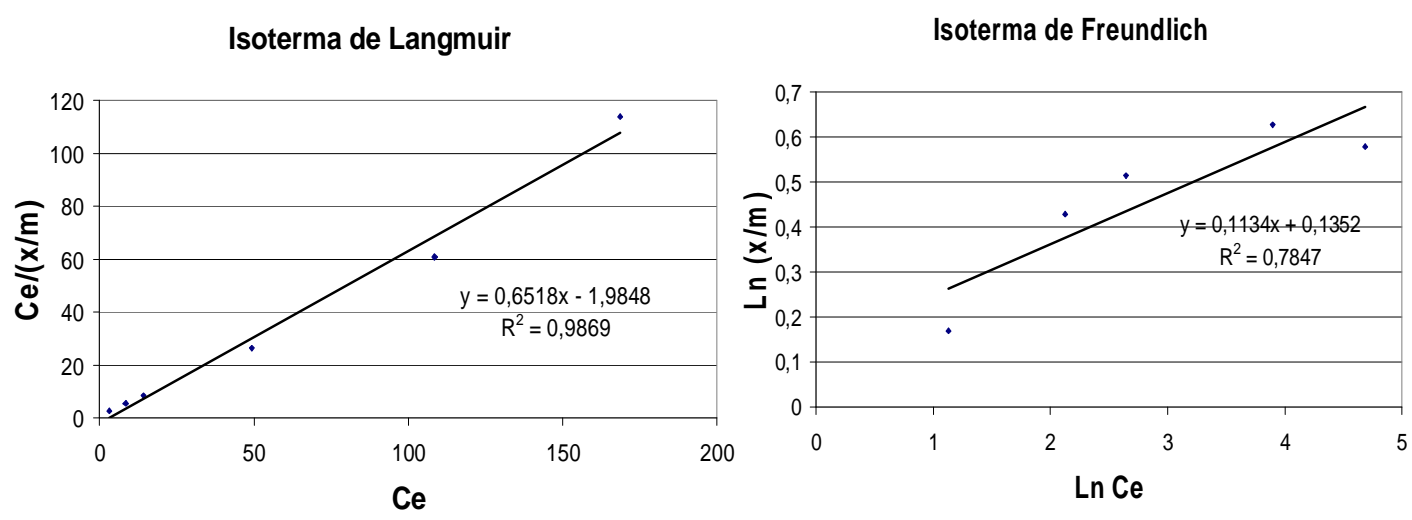

Figura 4.6 - Isotermas de Freundlich e Langmuir obtidas para o carvão 3.

\section{Primeira Fase da Terceira Etapa}

Na primeira fase desta terceira etapa foram utilizadas as mesmas dosagens de coagulante e oxidantes usadas na terceira fase da segunda etapa. Os parâmetros de mistura rápida, de coagulação e floculação também foram os mesmos. O intuito desta etapa foi verificar a remoção, pelo carvão ativado, da concentração restante de microcistina que não havia sido removida nos processos de oxidação e de coagulação. Foram coletadas amostras de duas velocidades de flotação, 26 e $13 \mathrm{~cm} / \mathrm{min}$. Um fluxograma ilustrativo da grade de ensaios desta fase estão apresentados na Figura 4.7. 


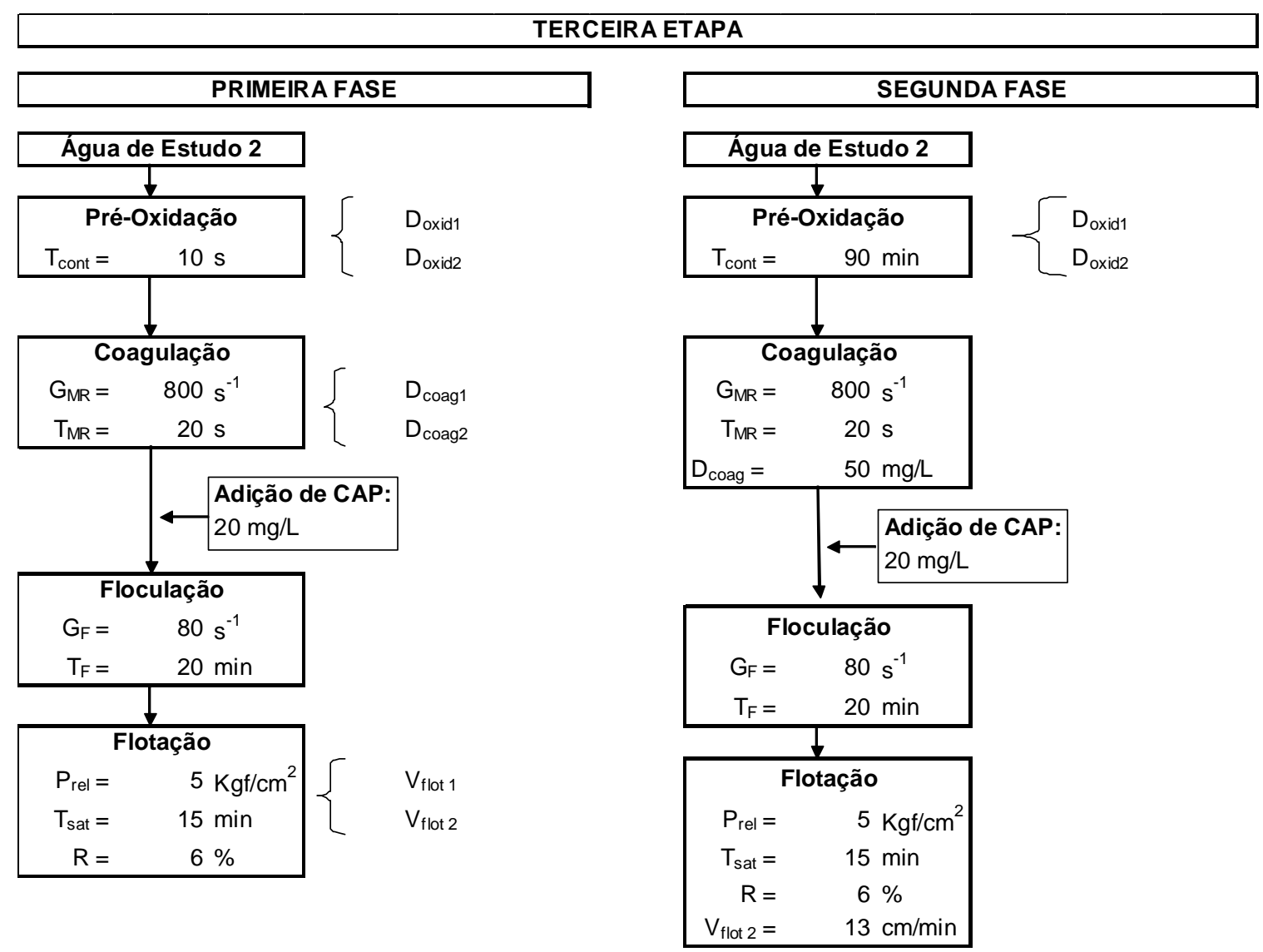

Figura 4.7 - Fluxograma ilustrativo dos ensaios da Terceira Etapa

\section{Segunda Fase da terceira Etapa}

Conforme mostrado no fluxograma da Figura 4.7, os ensaios da segunda fase foram feitos com a dosagem de coagulante que apresentou melhor resultado na primeira fase da terceira etapa - $50 \mathrm{mg} / \mathrm{L}$. O tempo de contato do oxidante, que teve duas dosagens estudadas, antes da coagulação foi de 90 minutos. Os parâmetros de coagulação, floculação e flotação foram fixos e são os mesmo da fase anterior. Apenas uma velocidade de flotação foi estudada. 


\section{4 - Equipamento Utilizados nos Ensaios}

O estudo de flotação foi feito com equipamentos denominados Jarteste e Flotateste. O Jarteste foi empregado para a etapa de mistura rápida e o Flotateste para as demais etapas do tratamento: floculação e flotação.

\subsection{1 - Jarteste}

Foram usados quatro jarros do equipamento, dos seis disponíveis,pois o ensaio no Jarteste (Figura 4.8), é seguido do ensaio em Flotateste e este possui apenas quatro jarros. Esses jarros construídos em acrílico transparente têm capacidade de 2,3 L cada, com lados de $11,5 \mathrm{~cm}$ e altura útil de $15,1 \mathrm{~cm}$. Possui um controlador de rotações que permite regular a agitação equivalente ao gradiente médio de velocidade desejado.

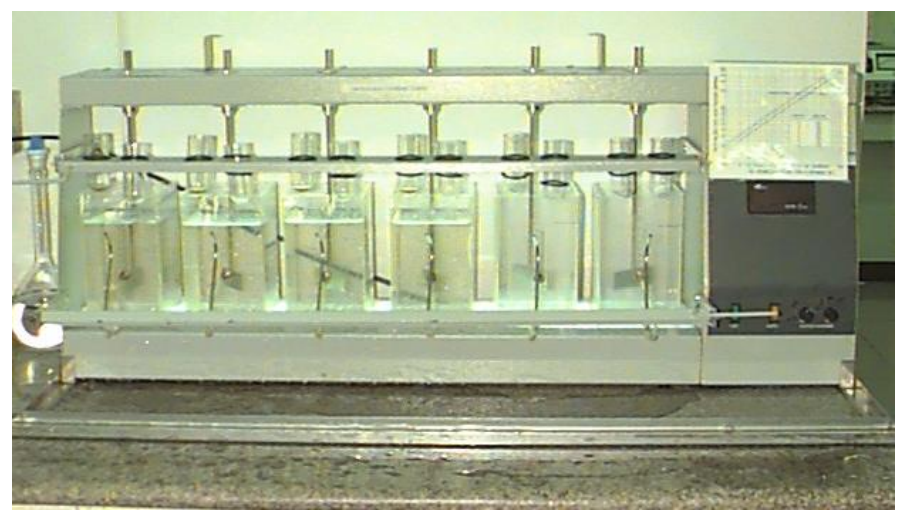

Figura 4.8 - Foto do Equipamento de Mistura Rápida Jarteste

O gradiente médio de velocidade de mistura rápida foi de $800 \mathrm{~s}^{-1}$ e o tempo de mistura rápida $20 \mathrm{~s}$. Em todos os ensaios em que também foram usados o oxidante e o carvão ativado em pó, estes foram dosados nesse equipamento. $\mathrm{O}$ Jarteste também foi utilizado para o ensaio que simulou a aplicação do oxidante 
no ponto de captação de água bruta e o gradiente médio de velocidade foi calculado com as seguintes suposições, adotando:

- Adutora de 9000 m de extensão e 60 cm de diâmetro interno;

- Velocidade de escoamento da água na tubulação de 1,65 m/s;

- Tubulação de ferro fundido após 15-20 anos de uso.

A perda de carga unitária na tubulação foi calculada pela Fórmula de Hazen-Williams cuja expressão é:

$$
J=10,65 \cdot \frac{Q^{1,85}}{C^{1,85} \cdot D^{4,87}}
$$

onde: $\mathrm{J}=$ perda de carga unitária $(\mathrm{m} / \mathrm{m})$

$$
\begin{aligned}
& Q=\text { vazão }\left(\mathrm{m}^{3} / \mathrm{s}\right) \\
& D=\text { diâmetro da tubulação }(\mathrm{m}) \\
& C=\text { coeficiente de rugosidade }- \text { para ferro fundido } C=100\left(\mathrm{~m}^{0,367} / \mathrm{s}\right)
\end{aligned}
$$

A perda de carga na tubulação é dada por:

$$
\Delta h=J . L
$$

onde: $\Delta \mathrm{h}=$ perda de carga $(\mathrm{m})$

$\mathrm{L}=$ comprimento da tubulação $(\mathrm{m})$

O gradiente médio de velocidade é dado pela equação mostrada por Di Bernardo (1993), apresentada a seguir:

$$
G=\sqrt{\frac{\gamma . \Delta h}{\mu . T}}
$$


onde: $\mathrm{G}=$ gradiente de velocidade médio $\left(\mathrm{s}^{-1}\right)$

$\gamma=$ peso específico da água $\left(\mathrm{N} / \mathrm{m}^{3}\right)$

$\mu=$ viscosidade absoluta da água (N.m/ $\left./ \mathrm{s}^{2}\right)$

$\mathrm{T}$ = tempo médio de detenção (s)

Utilizando a Equação 3 tem-se o gradiente de velocidade médio na tubulação de $398 \mathrm{~s}^{-1}$; adotou-se $400 \mathrm{~s}^{-1}$. Esse valor foi ajustado no Jarteste para simular a mistura que ocorreria do oxidante com a água de estudo durante os 90 minutos de contato.

\subsection{2 - Flotateste}

O equipamento Flotateste (Figura 4.9), desenvolvido por Reali (1991), é composto de quatro jarros de acrílico com $6,0 \mathrm{~cm}$ de diâmetro interno e capacidade útil de 2,3 L. Todos os jarros operam em regime de fluxo contínuo alimentação por batelada. Foi colocada nos jarros água já coagulada com volume de $1,90 \mathrm{~L}$ e, com a recirculação utilizada de $6 \%$, o volume final era $2,01 \mathrm{~L}$.

A saturação da água com ar foi feita no interior da câmara de saturação à pressão média de $500 \mathrm{kPa}$, obtida por meio de compressores de ar. O tempo de saturação de água na câmara era de 15 minutos. 


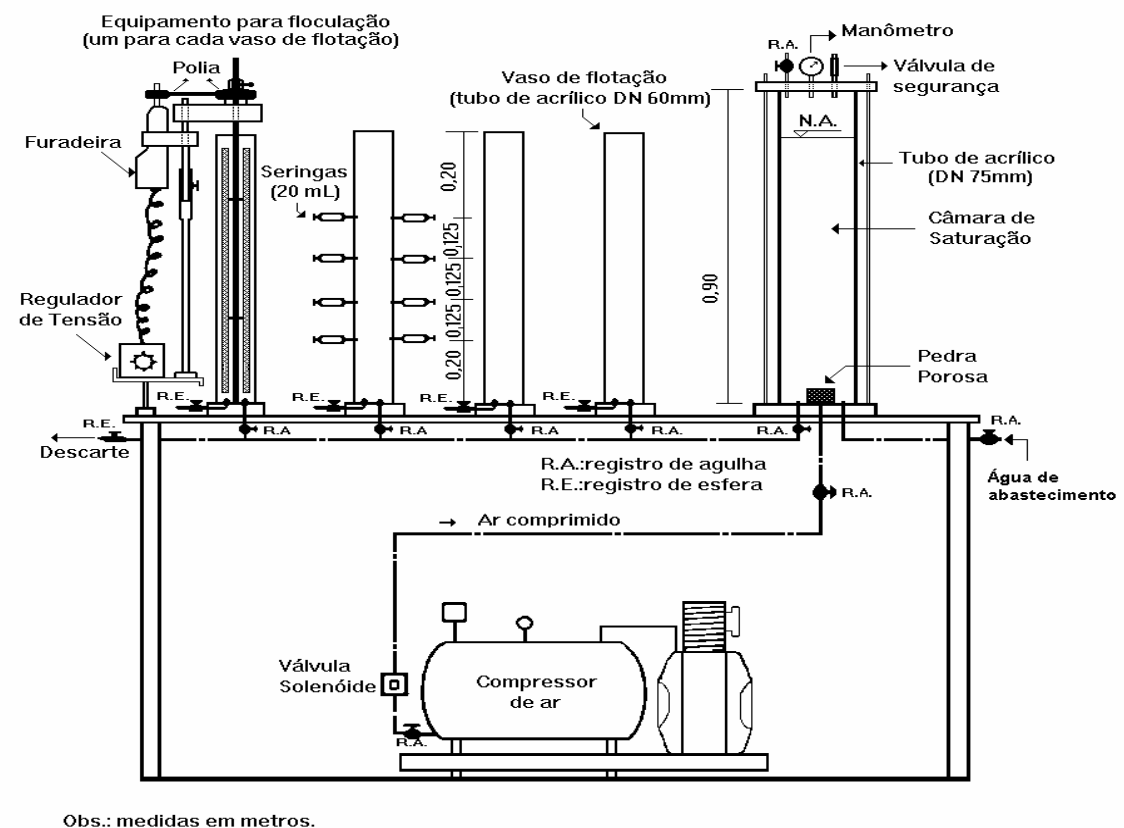

Figura 4.9 - Esquema ilustrativo do Flotateste.

Todos os jarros possuem agitadores próprios e independentes, conectados a um regulador de tensão para controle da agitação das pás giratórias. Os parâmetros de floculação foram: gradiente de velocidade médio de $80 \mathrm{~s}^{-1}$ e tempo de floculação de 20 minutos.

A coleta de amostras foi feita com o auxílio de torneiras posicionadas nas laterais dos jarros e foram coletadas amostras com duas velocidade de flotação, $13 \mathrm{~cm} / \mathrm{min}$ e $26 \mathrm{~cm} / \mathrm{min}$. 


\section{5 - Descrição dos Métodos Empregados na Pesquisa para Determinação de Clorofila-a, Trihalometanos e Microcistina.}

\subsection{1 - Método de Determinação de Clorofila-a}

A clorofila-a foi determinada de acordo com o método descrito por Nush (1980) explicado a seguir.

Primeiramente filtra-se um volume conhecido das amostras a serem analisadas em membrana com poros de 0,45 $\mu \mathrm{m}$ de diâmetro (Whatman 40). Essas membranas devem ser secas, no escuro, em dessecador. Após a secagem as membranas devem ser colocadas em tubos de ensaios tampados contendo volume de $10 \mathrm{~mL}$ de etanol $80 \%$. Os tubos devem ser aquecidos até a temperatura de $75^{\circ} \mathrm{C}$ e mantidos à essa temperatura durante cinco minutos. Em seguida os tubos são colocados em água com gelo, previamente preparada, e mantidos imersos durante cinco minutos. Após esse procedimento os tubos são guardados em geladeira à $4{ }^{\circ} \mathrm{C}$ durante doze horas, antes de ser feita a leitura de absorbância da solução de etanol presente nos tubos utilizados. Essa leitura de absorbância deve ser feita, em espectrofotômetro, em dois comprimentos de onda distintos, $650 \mathrm{~nm}$ e $750 \mathrm{~nm}$. A concentração de clorofila-a, em mg/L, é dada por:

$$
C=\frac{U^{n} \cdot 10^{6} .10}{86 \cdot V_{\text {fil }}}
$$

onde: U' = (Absorbância em 650 nm) - (Absorbância em 750 nm)

$$
\begin{aligned}
& 10 \text { = volume de etanol } 80 \%(\mathrm{~mL}) \\
& 86 \text { = fator do etanol }
\end{aligned}
$$


$V_{\text {fil }}=$ Volume filtrado da amostra $(\mathrm{mL})$

\subsection{2 - Método de Determinação de Trihalometanos}

método utilizado para determinação de trihalometanos foi descrito por Hautman \& Munch (1997):

Em um frasco de vidro de $60 \mathrm{~mL}$, coloca-se $1 \mathrm{~g}$ de tampão seco - 1\% $\mathrm{Na}_{2} \mathrm{HPO}_{4}+99 \% \mathrm{KH}_{2} \mathrm{PO}_{4}-$ para acidificar e conservar a amostra. Colocam-se 60 $\mathrm{mL}$ de amostra nesse frasco e, em seguida, retiram-se do frasco $10 \mathrm{~mL}$ da amostra e descarta-se essa parcela. Adicionam-se $100 \mathrm{~mL}$ de padrão interno solução de brometo de pentafluortolueno $10 \mathrm{mg} / \mathrm{L}$ em metanol - e, a seguir, $5 \mathrm{~mL}$ de n-pentano - solvente de extração - e $10 \mathrm{~g}$ de $\mathrm{Na}_{2} \mathrm{SO}_{4}$ anidro. Após a adição dessas substâncias fecha-se o frasco com tampa de butila com teflon, lacra-se com lacre de alumínio e agita-se o frasco vigorosamente em agitador de tubos por 2 minutos. Para a leitura utiliza-se uma seringa, mantida refrigerada, para injetar, em cromatógrafo, $1 \mathrm{~mL}$ da amostra. O volume é retirado diretamente do frasco lacrado através da tampa de butila. Foi utilizado um Cromatógrafo a gás HP 5890, equipado com detector de captura de elétrons e coluna HP-5 30m x 0,32 mm x $0,25 \mathrm{~mm}$.

Foram construídas quatro diferentes curvas de trihalometanos: clorofórmio, bromodiclorometano, dibromoclorometano e bromofórmio. Cada um desses compostos tem um fator de resposta no cromatógrafo; o mesmo ocorre com padrão interno adicionado durante o procedimento. O valor de resposta de um dos compostos é dividido pelo valor dado para o padrão interno. Esse valor obtido é 
usado na equação da curva contruída para cada composto e o valor obtido é a concentração do composto, em mg/L. Isso se faz para todos os quatro compostos.

\subsection{3 - Método de Determinação de Microcistina}

A toxina estudada nessa pesquisa foi determinada com auxílio do kit microcistina em placa da Envirologix comercializado pela Sovereign Brasil. Esse kit é composto por uma placa de 96 cavidades revestidas por anticorpos de microcistina-LR, por padrões com concentrações de 0,$16 ; 0,6$ e $2,5 \mu \mathrm{g} / \mathrm{L}$ de microcistina, um frasco de controle negativo, sem microcistina, um frasco de diluente, um frasco de conjugado, microcistina/enzima, um frasco de substrato, um frasco de solução "STOP" e uma embalagem de sal usado para preparo da solução de lavagem. O resultado é obtido em cerca de duas horas e o kit atende à Portaria do Ministério da Saúde número 518/04 de 23 de março de 2004 que regulamenta também o controle de toxinas.

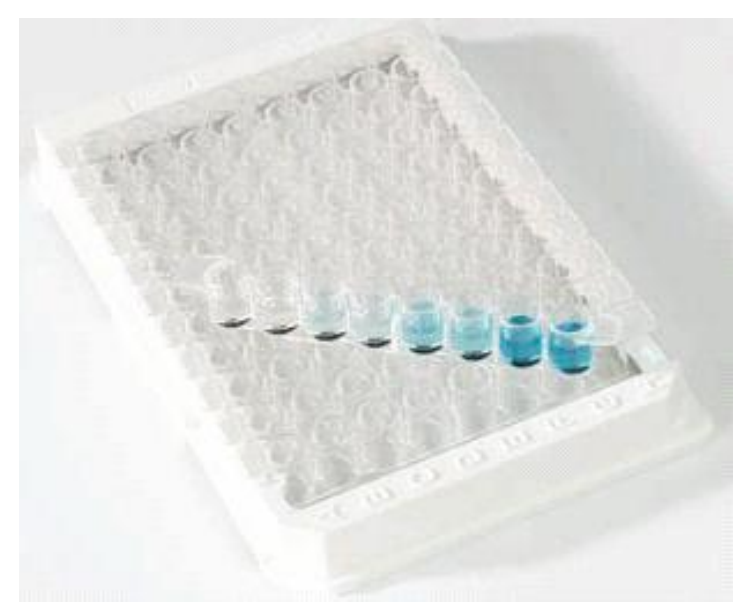

Figura 4.10 - Placa para determinação que integra o Kit 
Esse kit baseia-se na técnica de ELISA (Enzyme Linked ImmunoSorbent Assays) ou método de análise por imunoadsorção da enzima ligada. Esse método é baseado na competição entre dois grupos de antígenos sobre um número limitado de anticorpos que estão adsorvidos nas paredes das cavidades. 0 primeiro antígeno que se liga aos anticorpos das cavidades é a toxina presente na amostra. Em seguida ao adicionar-se o conjugado, este se liga aos anticorpos que não se ligaram à toxina. Após a lavagem das cavidades, adiciona-se o substrato, responsável pelo desenvolvimento de cor. A solução "STOP" é então adicionada para parar a reação. Um esquema ilustrativo do processo é apresentado na Figura 4.11 .

De acordo com o fabricante, o máximo valor detectado de microcistina é de 2,5 $\mu \mathrm{g} / \mathrm{L}$ e o valor mínimo é $0,147 \mu \mathrm{g} / \mathrm{L}$. Para leituras de valores acima de 2,5 mg/L devem ser feitas diluições apropriadas. Amostras com concentrações desconhecidas eram diluídas segundo escala logarítmica de base dez (1:1, 1:10, $1: 100$ e $1: 1000)$

A placa com as cavidades é então levada à Leitora de Microplacas Universal modelo ELx800 que faz a leitura de absorbância das cavidades. A leitora usa os resultados de absorbância dos padrões e constrói um curva que auxilia a determinação das concentrações de microcistinas das amostras a serem determinadas. 

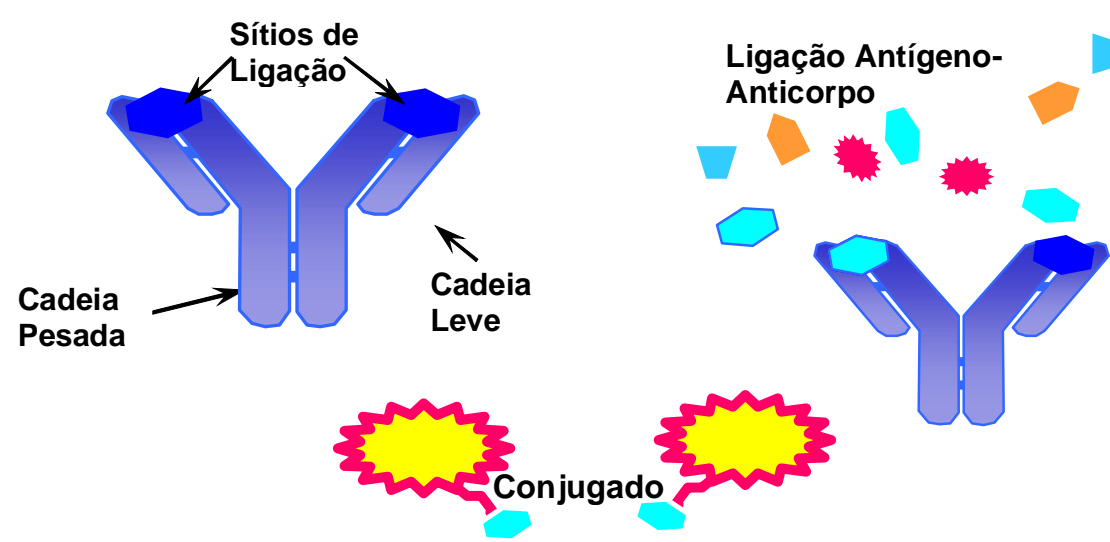

Ligação Antígeno-

Pesada

Cadeia

jugado
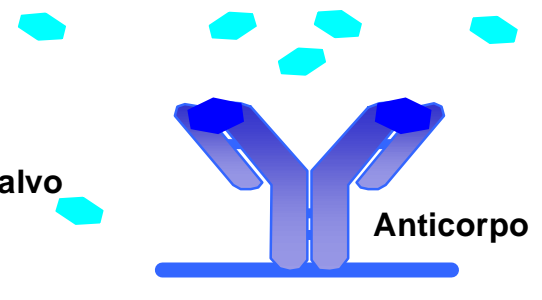

I. Pouca substância - Maior coloração

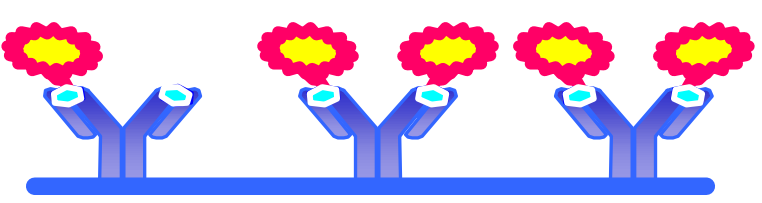

II. Muita substância - Menor coloração

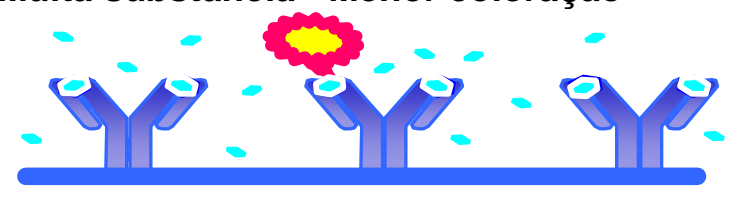

Figura 4.11 - Esquema ilustrativo do método de determinação de microcistina 


\section{5 - RESULTADOS E DISCUSSÕES}

\section{1 - Considerações Iniciais}

Os resultados apresentados nesse capítulo foram obtidos em ensaios realizados com águas preparadas a partir de duas campanhas de coleta junto ao reservatório de Barra Bonita, conforme descrito no capítulo 4. Foram feitos préensaios com o propósito de apenas consolidar a metodologia de ensaios e determinações de parâmetros a serem adotados; por esse motivo os resultados desses ensaios não são apresentados. Os resultados dos ensaios de tratabilidade sem pré-oxidação (1 ${ }^{\text {a }}$ Etapa) foram feitos pelo autor, pelo mestrando $\mathrm{Eng}^{\circ}$. André Luis Vieira da Silva e pelo doutorando Eng ${ }^{\circ}$ Maurício Fernandes Perez.

\section{2 - Resultados da Primeira Etapa}

Na Tabela 5.1 estão apresentados os resultados de caracterização da água de estudo 1, utilizada nessa primeira etapa dos ensaios. Também estão presentes as caracterizações da cultura e da água do reservatório. 
Tabela 5.1 - Caracterização da cultura, da água do resenatório e da água de estudo 1.

\begin{tabular}{cccc}
\hline & Cultura & $\begin{array}{c}\text { Água do } \\
\text { Reservatório }\end{array}$ & $\begin{array}{c}\text { Água de } \\
\text { Estudo }\end{array}$ \\
\hline Cor Aparente & - & - & 412 \\
(uH) & - & - & 122 \\
Turbidez (uT) & 6,85 & 7,48 & 7,08 \\
pH & 691 & 201 & 245 \\
ST (mg/L) & 427 & 17 & 22 \\
DQO (mg/L) & 93 & 62 & 71 \\
NTK (mgN/L) & $\mathrm{Nd}^{*}$ & $\mathrm{Nd}^{*}$ & $\mathrm{Nd}^{*}$ \\
P (mg/L) & 1,05 & 0,21 & 0,28 \\
Absorbância & & & \\
$254 \mathrm{~nm}$ & & 69,8 & 66,2 \\
Alcalinidade & 128,9 & & \\
(mgCaCO3/L) & & &
\end{tabular}

\subsection{1 - Primeira Fase da Primeira Etapa}

Nas Figuras 5.1 a 5.8 estão apresentados curvas de remoção de cor aparente e turbidez e diagramas de eficiência de remoção para esses parâmetros. 


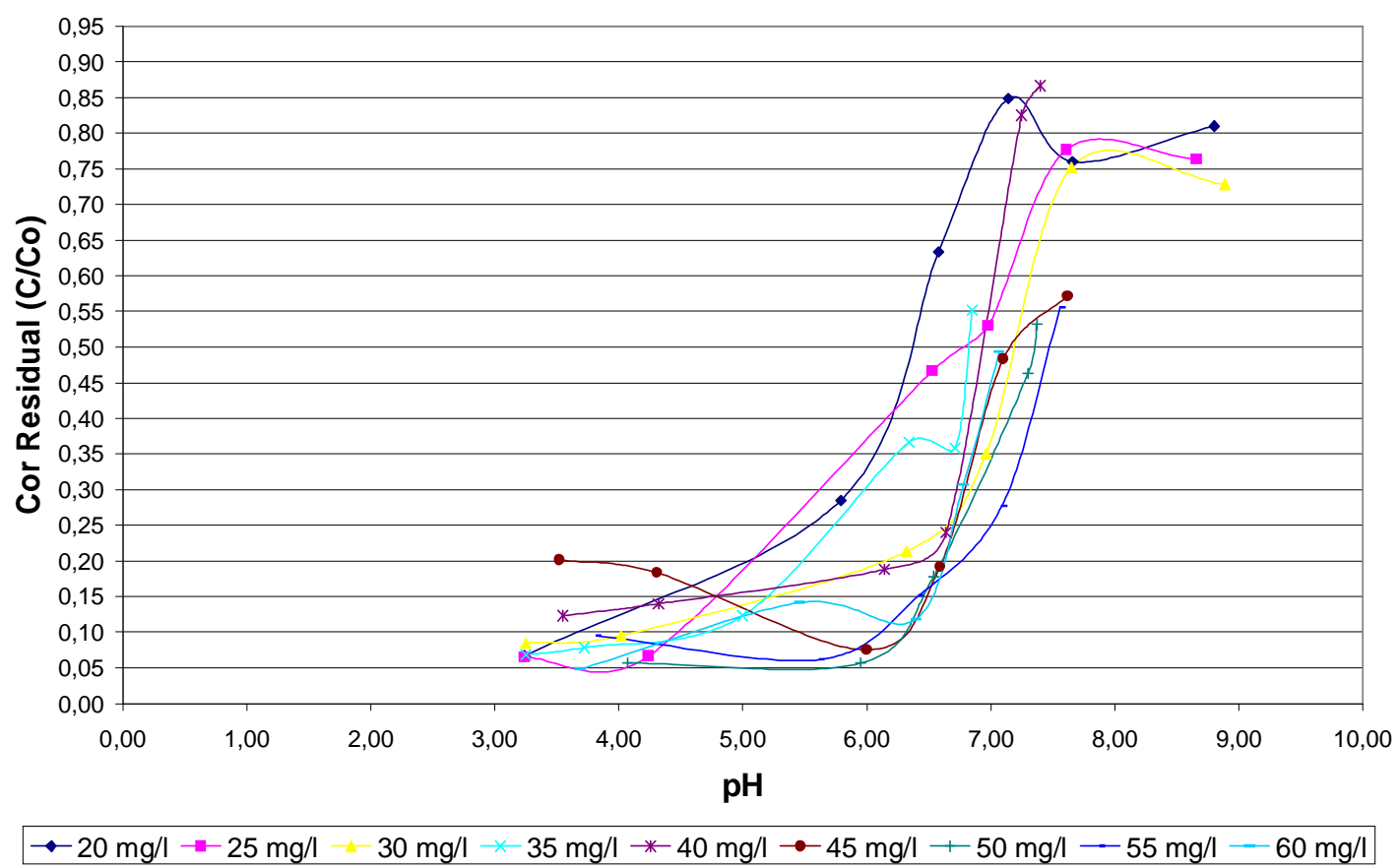

Figura 5.1 - Curvas de Cor aparente residual para cada dosagem de coagulante com variação do $\mathrm{pH}$ de coagulação, para amostras coletadas na velocidade 1 ( $\mathrm{v}=15,6 \mathrm{~m} / \mathrm{h}$ ).

\section{Eficiência de Remoção de Cor}

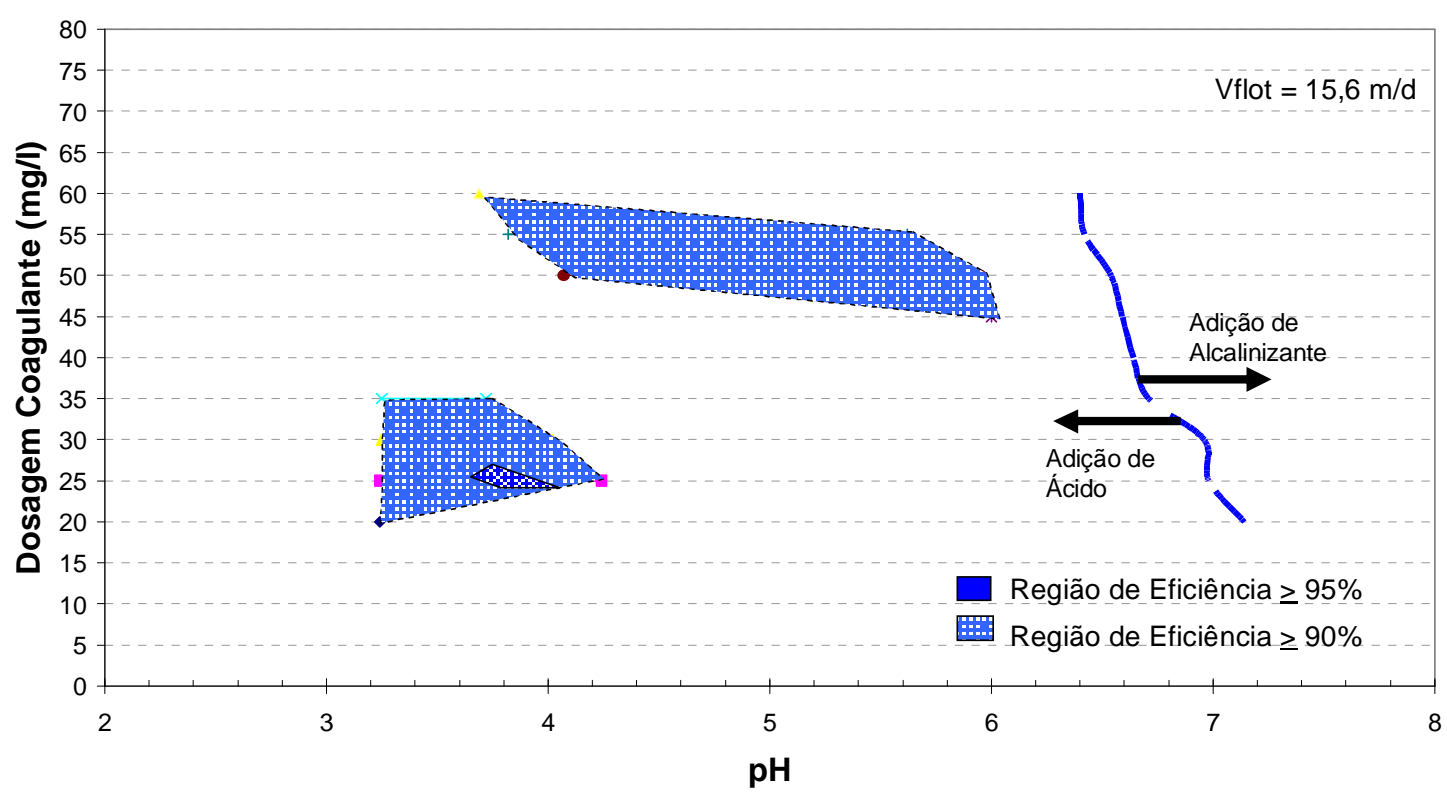

Figura 5.2 - Diagrama de coagulação, visando flotação, construído a partir da figura 5.1 delimitando as regiões de eficiência de remoção de cor aparente para a velocidade 1. 


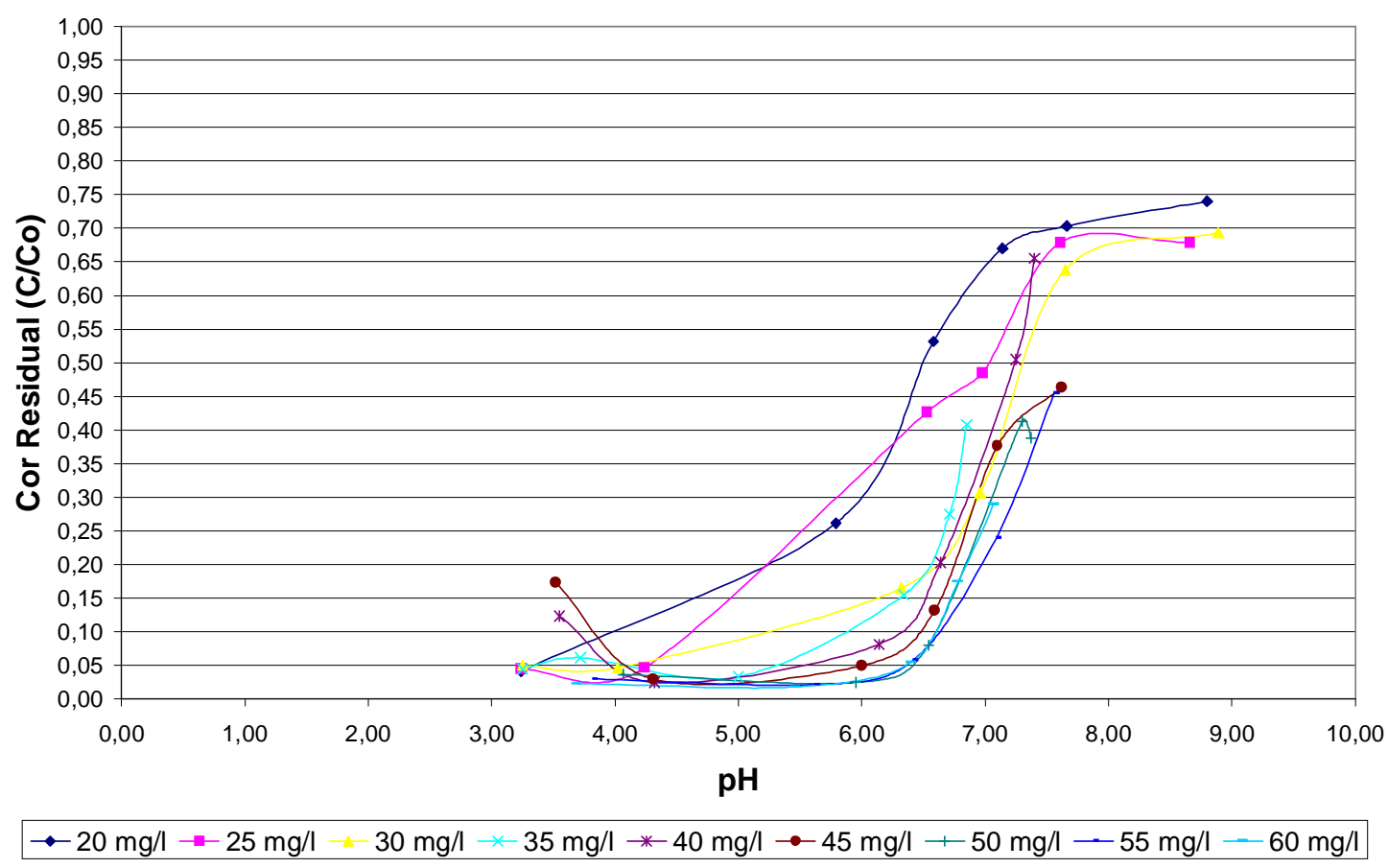

Figura 5.3 - Curva de Cor aparente residual para cada dosagem de coagulante com variação do $\mathrm{pH}$ de coagulação, para amostras coletadas na velocidade $2(\mathrm{v}=7,8 \mathrm{~m} / \mathrm{h}$ ).

\section{Eficiência de Remoção de Cor}

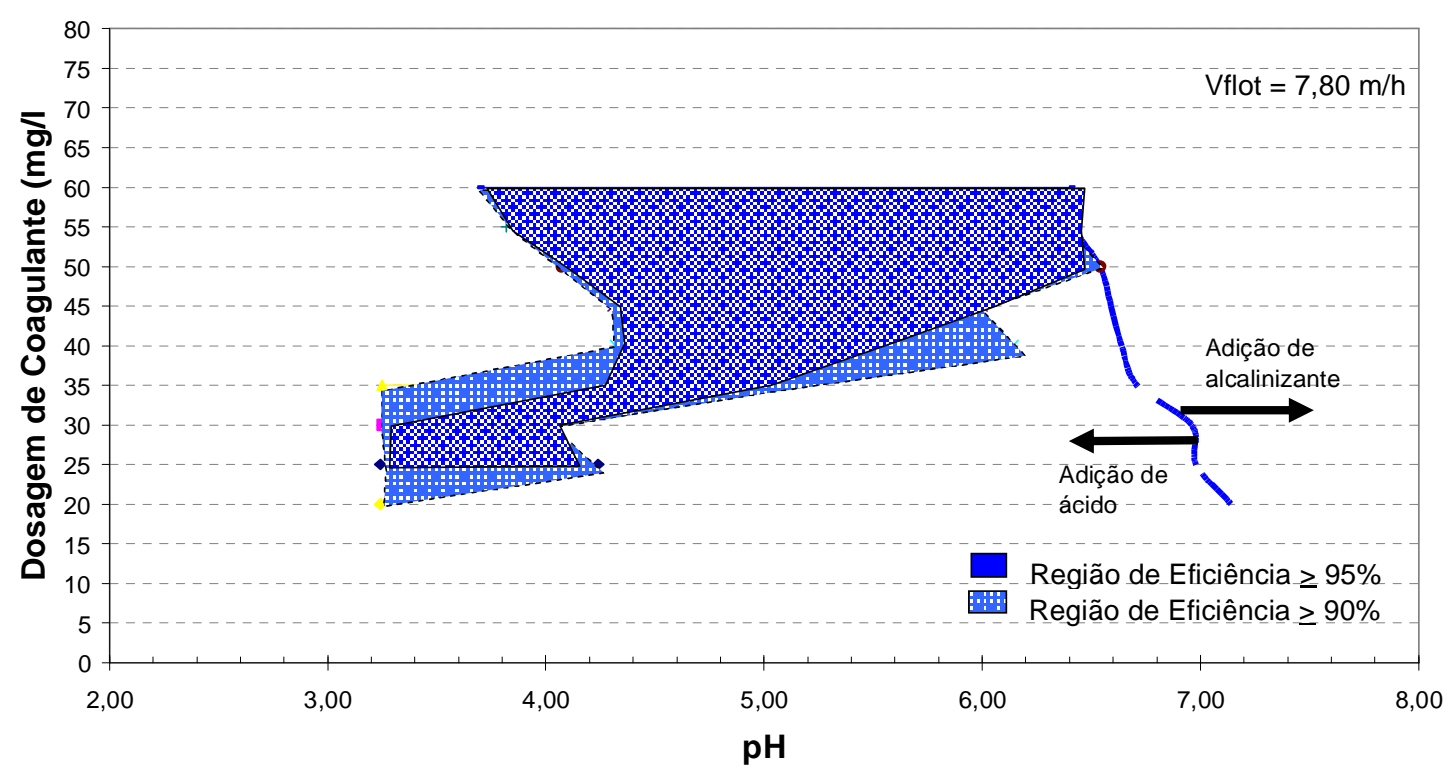

Figura 5.4 - Diagrama de coagulação, visando flotação, construído a partir da figura 5.3 delimitando as regiões de eficiência de remoção de cor aparente para a velocidade 2 . 


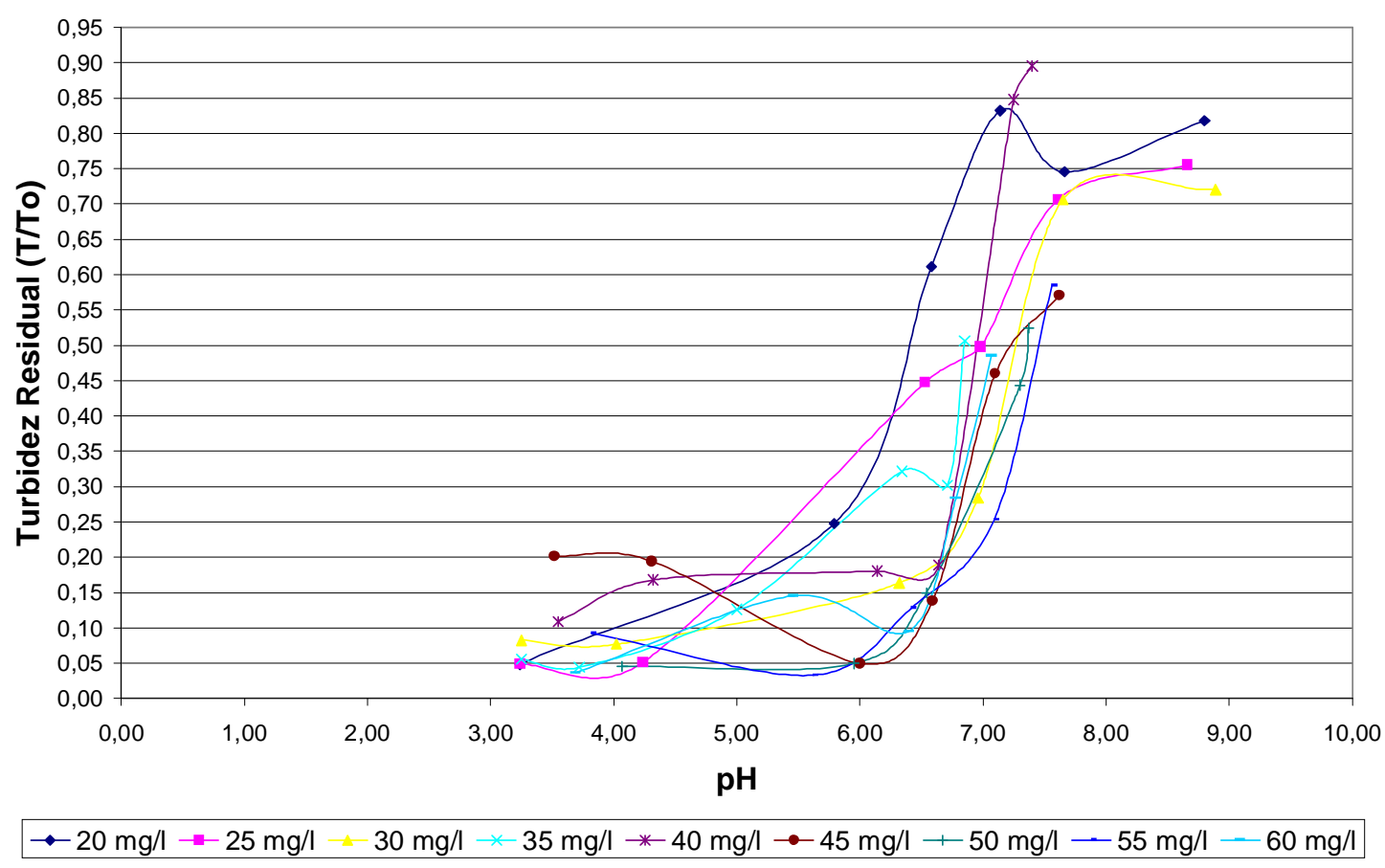

Figura 5.5 - Curvas de Turbidez residual para cada dosagem de coagulante com variação do $\mathrm{pH}$ de coagulação, para amostras coletadas na velocidade 1 ( $\mathrm{v}=15,6 \mathrm{~m} / \mathrm{h}$ ).

\section{Eficiência de Remoção de Turbidez}

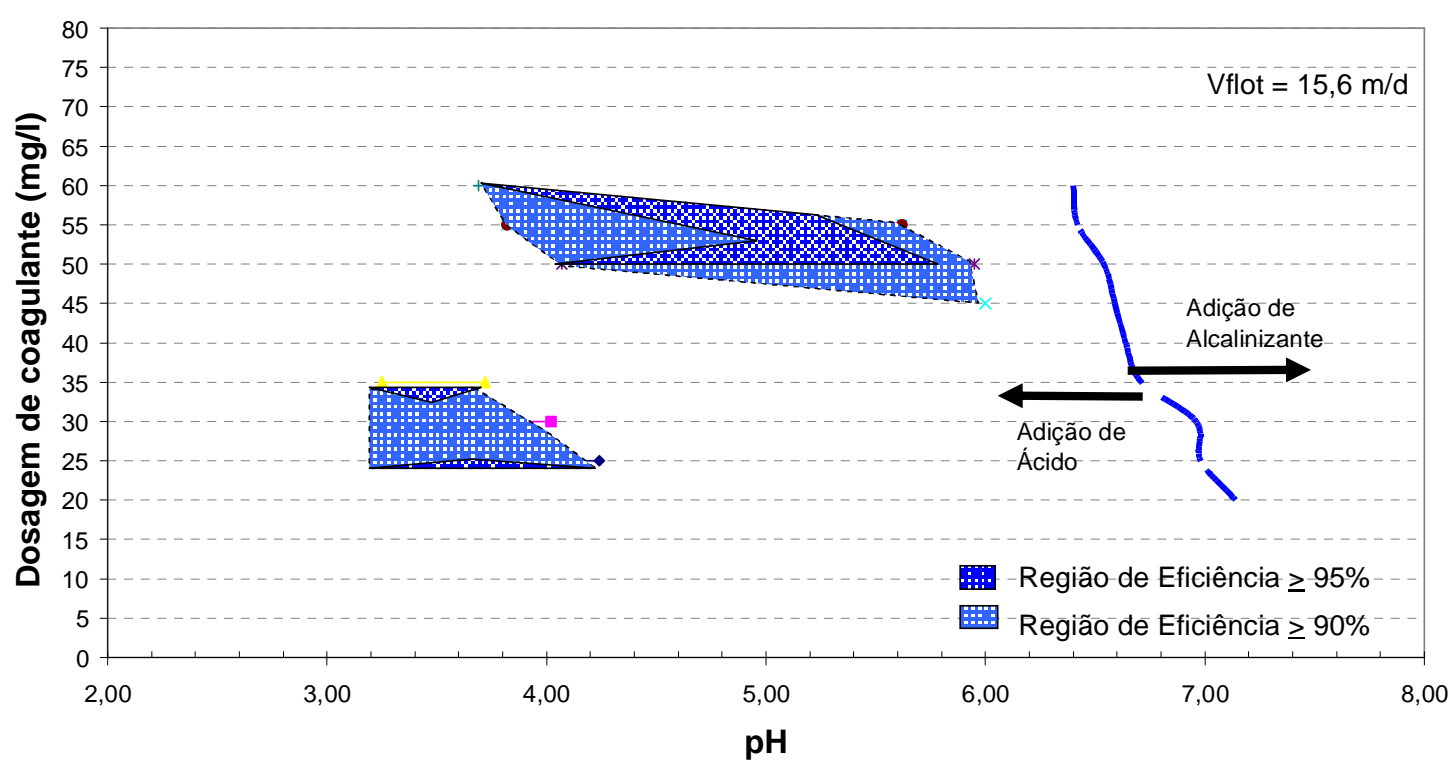

Figura 5.6 - Diagrama de coagulação, visando flotação, construído a partir da figura 5.5 delimitando as regiões de eficiência de remoção de turbidez para a velocidade 1. 


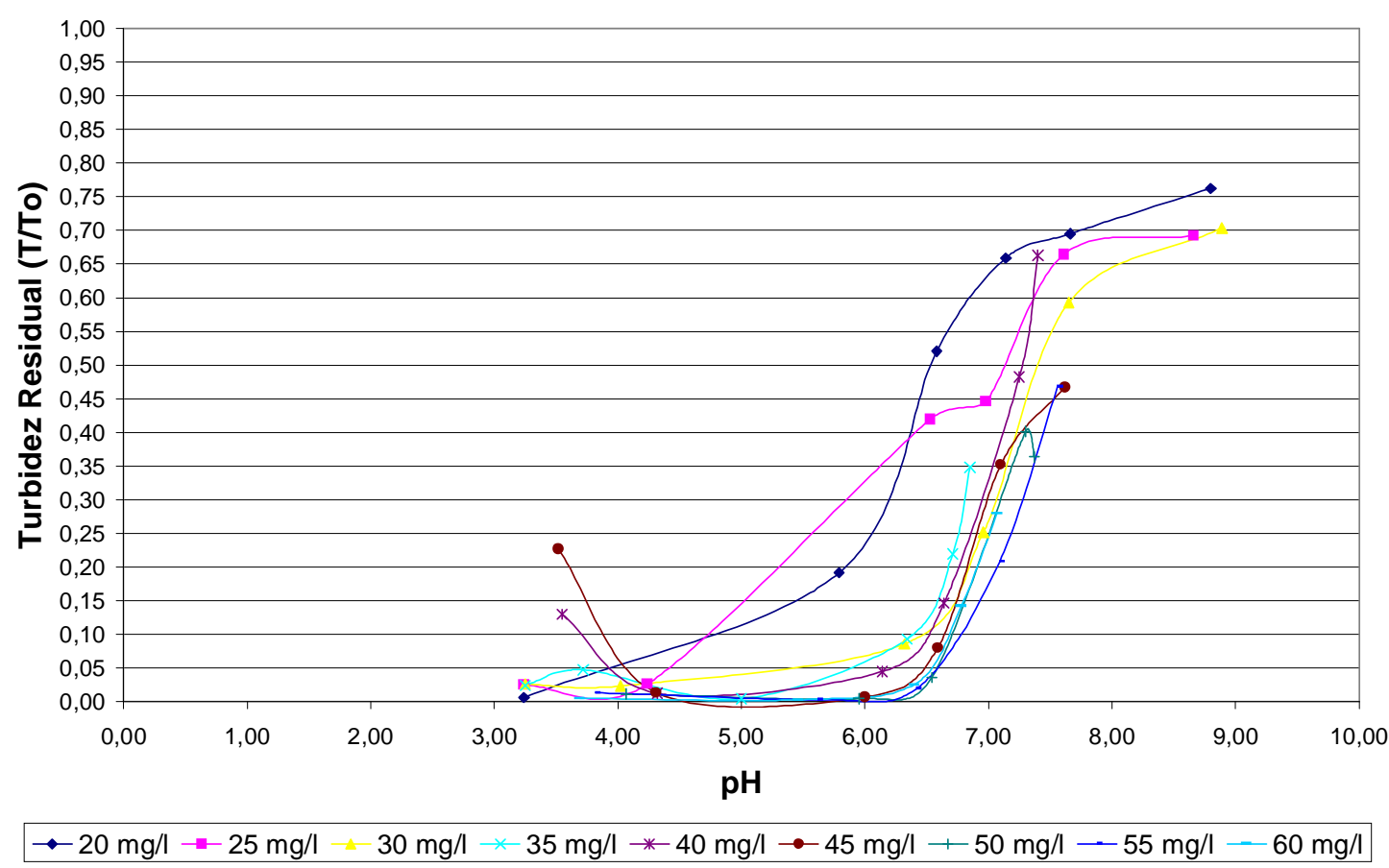

Figura 5.7 - Curva de Turbidez residual para cada dosagem de coagulante com variação do $\mathrm{pH}$ de coagulação, para amostras coletadas na velocidade $2(\mathrm{v}=7,8 \mathrm{~m} / \mathrm{h})$.

\section{Eficiência de Remoção de Turbidez}

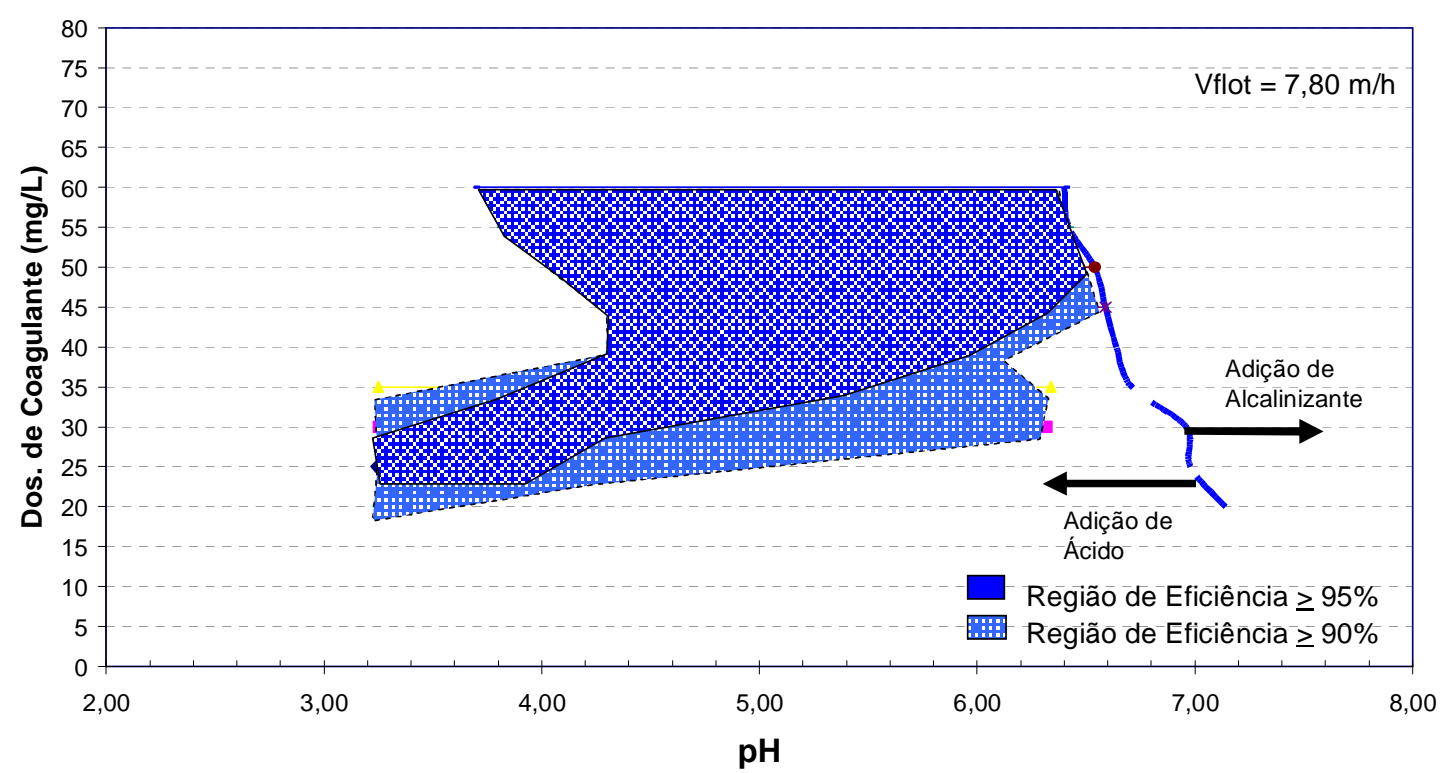

Figura 5.8 - Diagrama de coagulação, visando flotação, construído a partir da figura 5.7 delimitando as regiões de eficiência de remoção de turbidez para a velocidade 2. 
As Figuras anteriores mostram a importância do $\mathrm{pH}$ na eficiência do tratamento da água de estudo. Nota-se que quando se dosou alcalinizante não se obteve resultados de 90 \% ou mais de remoção. O mesmo não aconteceu quando se dosou ácido. Para todas as dosagens de coagulante até $40 \mathrm{mg} / \mathrm{L}$ os resultados não foram piores. Mesmo com pH bem baixos como, por exemplo, para as dosagens de 20, 25, 30 e 35 mg/L e valores de pH em torno de 3,5 a eficiência de remoção de cor e turbidez foi bem elevada para ambas as velocidades de flotação.

A partir da dosagem de $40 \mathrm{mg} / \mathrm{L}$ para os valores mais baixos estudados observou-se uma pequena piora na eficiência de remoção de cor e turbidez e, possivelmente, para valores ainda mais baixos de $\mathrm{pH}$ ter-se-ia a tendência de piorar ainda mais.

Em tratamento de água de abastecimento não é de hábito trabalhar com valores muito baixos de $\mathrm{pH}$, como por exemplo: faixa de $\mathrm{pH}$ de 3 a 5 , tendo em vista o aumento da corrosividade da água. Sempre que possível, procura-se evitar a aplicação de ácido nas estações de tratamento devido à sua periculosidade e, por conseqüência, há dificuldade em se trabalhar com esse tipo de produto. $\mathrm{O}$ coagulante tem um caráter ácido, ou seja, quanto maior a dosagem de coagulante mais ácido será o pH de coagulação. Como a água utilizada possui alcalinidade suficientemente elevada e requer valor de $\mathrm{pH}$ na faixa ácida - abaixo de 6,5 para conseguir remoção satisfatória, o procedimento adotado foi aumentar a dosagem de coagulante acima de $40 \mathrm{mg} / \mathrm{L}$ com vistas a se tomar partido da acidez que o próprio coagulante confere à água. 
Portanto optou-se pela aplicação de dosagens maiores nas etapas posteriores do trabalho - entre 40 e $55 \mathrm{mg} / \mathrm{L}$-, sem adição de álcali ou ácido, exceto nos ensaios de tratabilidade da segunda fase da primeira etapa quando foi dosado ácido para variar o $\mathrm{pH}$.

\subsection{2 - Segunda Fase da Primeira Etapa}

Para esta segunda fase, inicialmente foi necessário determinar a dosagem de oxidante a ser utilizado ao longo dos ensaios. Para isso construiu-se uma curva de residual de cloro em função da dosagem de $\mathrm{NaOCl}$ (tempo de contato igual a 30 minutos). A mesma água de estudo preparada para os ensaios da primeira fase foi usada para serem efetuados ensaios de tratabilidade com adição de préoxidante 10 segundos antes da coagulação.

As dosagens do oxidante testadas nas etapas subseqüentes da pesquisa foram determinadas com base na curva de residual de cloro livre apresentada na Figura 5.9. 


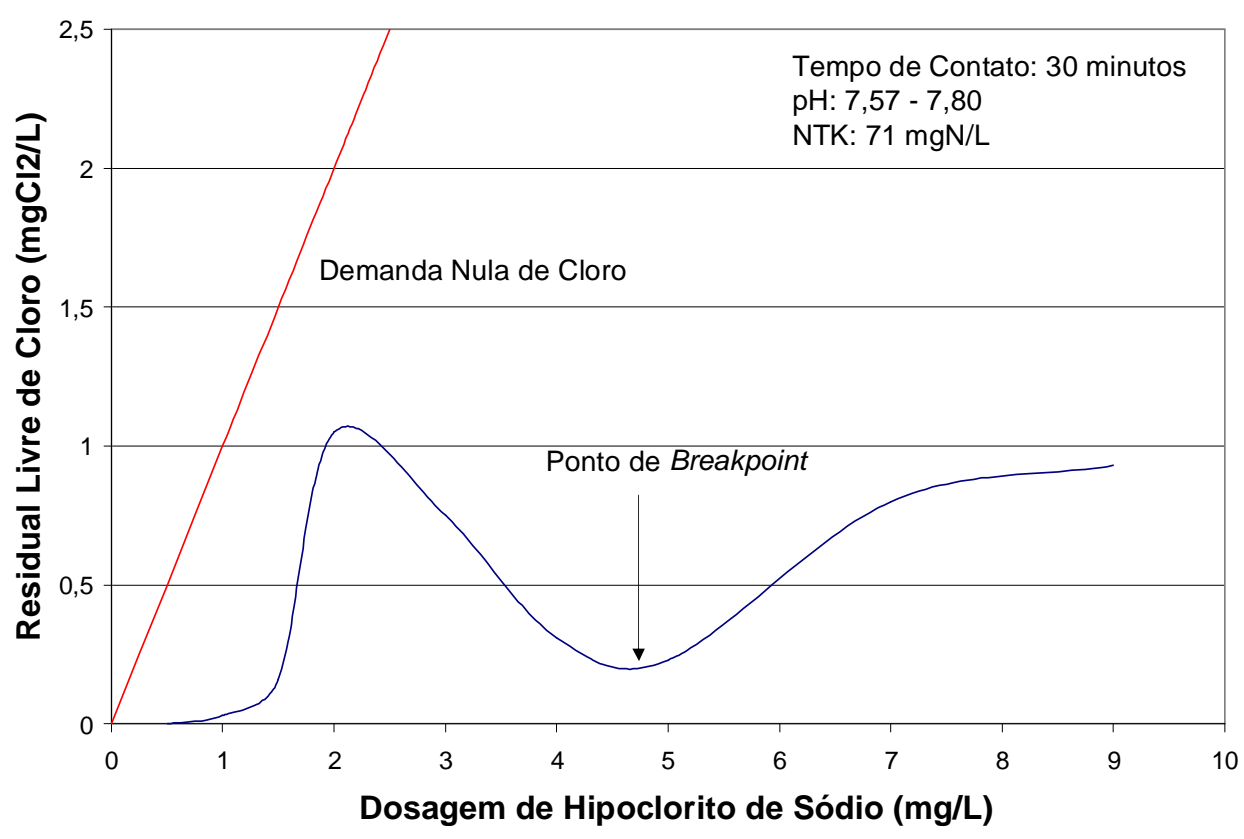

Figura 5.9 - Cloro residual em relação à dosagem de hipoclorito de sódio para a água de estudo.

Observando a curva mostrada na Figura 5.9, verifica-se que para dosagens de hipoclorito de sódio até cerca de $2,1 \mathrm{mg} / \mathrm{L}$ tem-se a produção de diferentes tipos de cloraminas. O ponto de inflexão, que se forma a partir desse valor, indica que a cloramina e/ou outros compostos formados são oxidados até o valor de cerca de $4,8 \mathrm{mg} / \mathrm{L}$ de hipoclorito de sódio. Nesse outro ponto de inflexão ocorre o breakpoint, o qual caracteriza-se por formação de cloro livre para dosagens acima dele. As dosagens de hipoclorito de sódio escolhidas para os ensaios subseqüentes de oxidação/coagulação/flotação foram de $2,1 \mathrm{mg} / \mathrm{L}$ e $6,0 \mathrm{mg} / \mathrm{L}$. A primeira por ser o mais elevado ponto observado de residual de cloro livre e a 
segunda por posicionar-se depois do breakpoint - dosagem de 4,8 mg/L de $\mathrm{NaOCl}$

Nas Figuras seguintes (Figura 5.10 a 5.13) são apresentados os resultados de cor aparente e turbidez do ensaio de tratabilidade, efetuado com adição de hipoclorito de sódio como pré-oxidante. Para algumas dosagem de coagulante foram estudados dois valores de $\mathrm{pH}$; para isso foi usado uma solução ácida.

Valores de Cor Aparente para ensaios com dosagem de $2,1 \mathrm{mg} / \mathrm{L}$ de Hipoclorito de Sódio

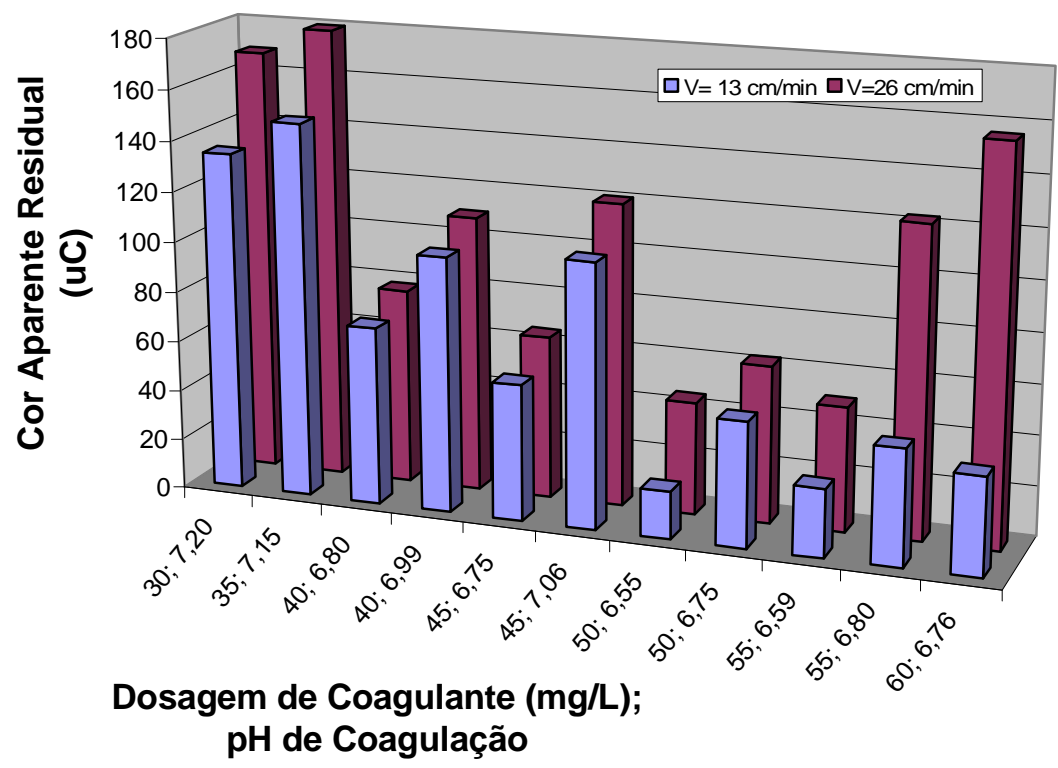

Figura 5.10 - Resultados de cor aparente em ensaios de flotação precedidos de préoxidação com dosagem de oxidante ( $\mathrm{NaOCl})$ de $2,1 \mathrm{mg} / \mathrm{L}$. 
Valores de Turbidez para ensaios com dosagem de 2,1 $\mathrm{mg} / \mathrm{L}$ de Hipoclorito de Sódio

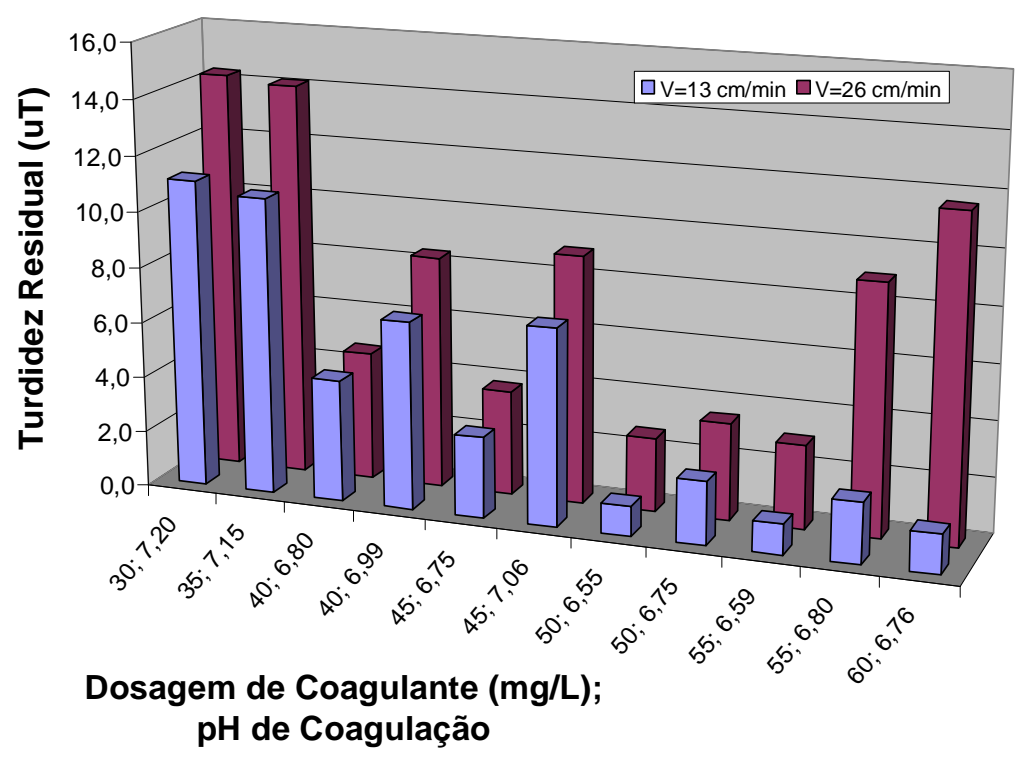

Figura 5.11 - Resultados de turbidez em ensaios de flotação precedidos de pré-oxidação com dosagem de oxidante $(\mathrm{NaOCl})$ de $2,1 \mathrm{mg} / \mathrm{L}$.

\section{Valores de Cor Aparente para ensaios com dosagem de $6,0 \mathrm{mg} / \mathrm{L}$ de Hipoclorito de Sódio}

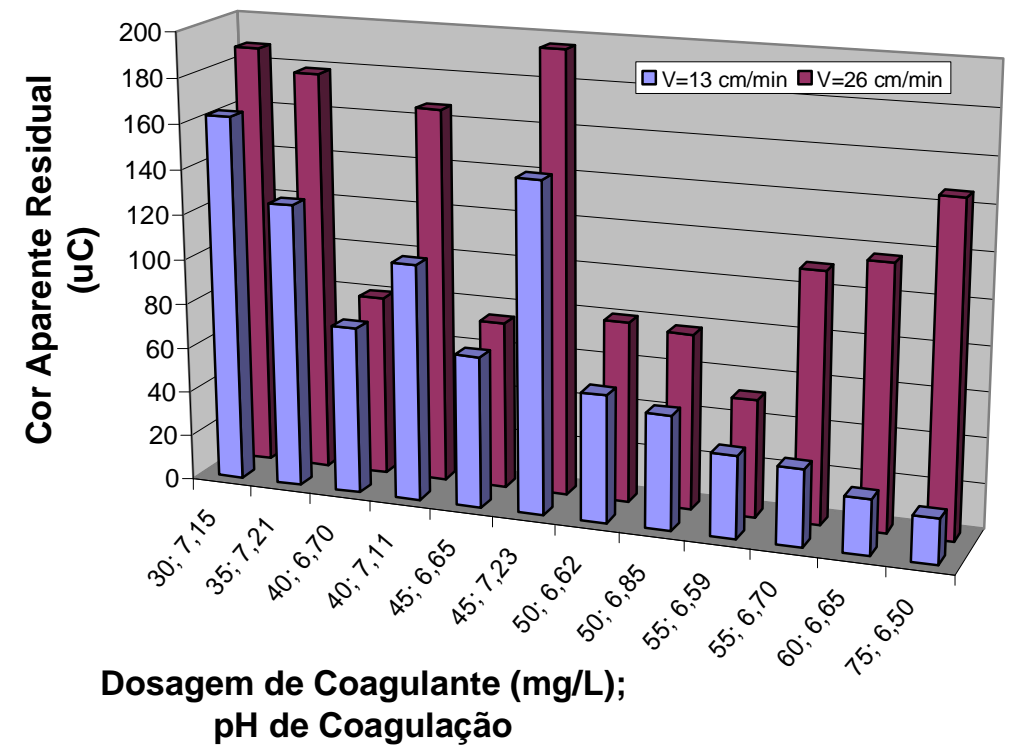

Figura 5.12 - Resultados de cor aparente em ensaios de flotação precedidos de préoxidação com dosagem de oxidante $(\mathrm{NaOCl})$ de $6,0 \mathrm{mg} / \mathrm{L}$ 


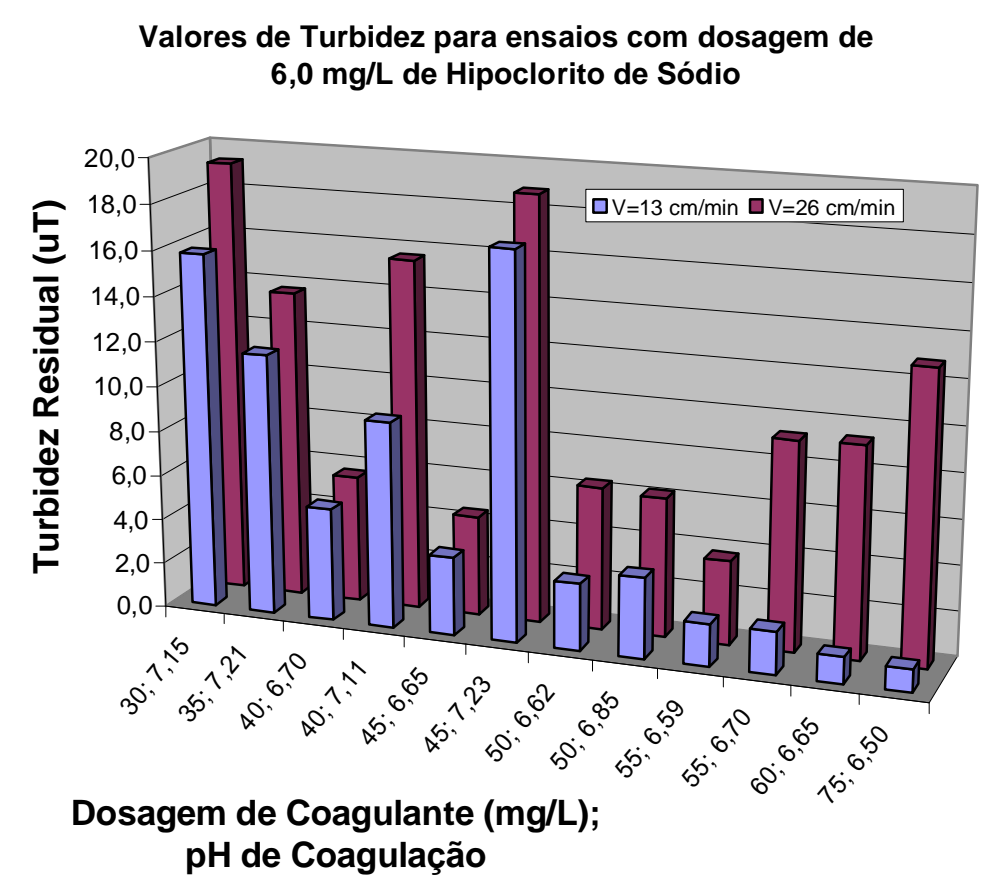

Figura 5.13 - Resultados de turbidez em ensaios de flotação precedidos de pré-oxidação com dosagem de oxidante $(\mathrm{NaOCl})$ de $6,0 \mathrm{mg} / \mathrm{L}$.

De maneira geral, comparando os resultados desta segunda fase (Figuras 5.10 a 5.13) com os da primeira (Figuras 5.1 a 5.8) nota-se que a adição de oxidante influiu negativamente na remoção de cor e turbidez, para uma mesma dosagem de coagulante. O hipoclorito de sódio tem caráter alcalino e tal como na primeira fase notou-se tendência dessa água em obter melhor remoção em pH baixo, como era de se esperar.

Analisando as Figuras 5.10 a 5.13, observa-se que para a dosagem de 2,1 $\mathrm{mg} / \mathrm{L}$ de oxidante, a melhor dosagem de coagulante foi de $50 \mathrm{mg} / \mathrm{L}$ obtendo-se melhores remoção de cor e turbidez para as duas velocidades estudadas. Para a dosagem de $6,0 \mathrm{mg} / \mathrm{L}$ de oxidante, os gráficos mostram que a partir de $50 \mathrm{mg} / \mathrm{L}$ houve certa tendência de melhor remoção dos parâmetros estudados; porém 
apenas para a velocidade de flotação de $13 \mathrm{~cm} / \mathrm{min}$; para a velocidade de 26 $\mathrm{cm} / \min$ o aumento da concentração de coagulante fez piorar a remoção. A primeira explicação seria ter havido algum erro nos procedimentos de coleta dessas amostras. Outra possibilidade para explicar tais resultados seria o fato de os flocos formados com dosagem de $6,0 \mathrm{mg} / \mathrm{L}$ de $\mathrm{NaOCl}$ e aplicação de dosagens de coagulante mais elevadas que $50 \mathrm{mg} / \mathrm{L}$ apresentarem características de tamanho e superfície que resultaram em velocidades ascencionais mais baixas desses flocos e, portanto, com menores eficiência de remoção quando as amostras foram extraídas da coluna de flotação após decorrido tempo menor de flotação - velocidade de flotação equivalente mais elevadas de $26 \mathrm{~cm} / \mathrm{min}$ ou 15,8 m/h. Por outro lado, nos mesmos ensaios, para amostras extraídas após período maior de flotação, velocidade de flotação equivalente a $13 \mathrm{~cm} / \mathrm{min}$ ou $7,8 \mathrm{~m} / \mathrm{h}$, esses mesmos flocos puderam ser removidos com eficiência crescente com o aumento da dosagem de coagulante, até $60 \mathrm{mg} / \mathrm{L}$ - com aplicação de $6,0 \mathrm{mg} / \mathrm{L}$ de $\mathrm{NaOCl}$ na etapa de pré-oxidação.

É interessante notar que, para dosagem de $2,1 \mathrm{mg} / \mathrm{L}$ de $\mathrm{NaOCl}$ na etapa de pré-oxidação, esse fenômeno não ocorreu, ficando claro que, nesse caso, as dosagens de coagulante na faixa de 50 a $55 \mathrm{mg} / \mathrm{L}$ fornecem as maiores eficiências de remoção de cor e turbidez por flotação nas duas situações de coleta de amostras da coluna de flotação. 


\section{3 - Resultados da Segunda Etapa}

Na tabela 5.2 estão apresentados os resultados da caracterização da água de estudo 2, lembrando que essa água é diferente da usada na primeira etapa por motivos já explicados. Na Figura 5.14 estão os resultados da contagem de organismos feita para a cultura preparada em laboratório, da água do reservatório e da água de estudo 2.

Tabela 5.2 - Caracterização da água de estudo 2

\begin{tabular}{lcc}
\hline \multicolumn{1}{c}{ Parâmetro } & Valor & Unidade \\
\hline Cor Aparente & 255 & $\mathrm{uC}$ \\
Turbidez & 35,1 & $\mathrm{uT}$ \\
Sólidos Totais & 247 & $\mathrm{mg} / \mathrm{L}$ \\
Sólidos Suspensos Totais & 16,3 & $\mathrm{mg} / \mathrm{L}$ \\
Alcalinidade & 46,5 & $\mathrm{mgCaCO} / \mathrm{L}$ \\
NTK & 4,0 & $\mathrm{mg} / \mathrm{L}$ \\
Nitrogênio Amoniacal & 0,15 & $\mathrm{mg} / \mathrm{L}$ \\
Fósforo & 0,27 & $\mathrm{mg} / \mathrm{L}$ \\
Absorbância 264nm & 0,18 & \\
DQO & 93 & $\mathrm{mg} / \mathrm{L}$ \\
Coliformes Totais & 72 & $\mathrm{UFC} / 100 \mathrm{~mL}$ \\
Coliformes Termotolerantes & 10 & $\mathrm{UFC} / 100 \mathrm{~mL}$ \\
Clorofila-a & 26,9 & $\mu \mathrm{g} / \mathrm{L}$ \\
Microcistina & 14,45 & $\mu \mathrm{g} / \mathrm{L}$ \\
\hline
\end{tabular}


Distribuição dos Organismos Fitoplanctônicos na Cultura em \%

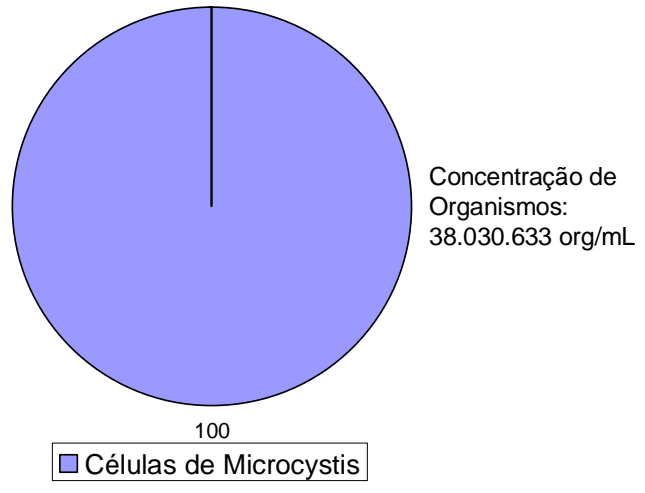

Distribuição dos Organismos Fitoplanctônicos na Água do Reservatório em \%

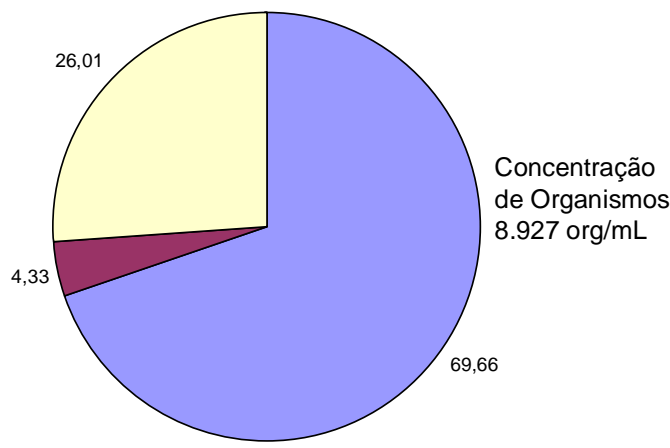

$\square$ Células de Microcystis $\square$ Colônias de Microcystis $\square$ Outros Organismos Fitoplanctônicos

Distribuição dos Organismos Fitoplanctônicos na Água de Estudo em \%

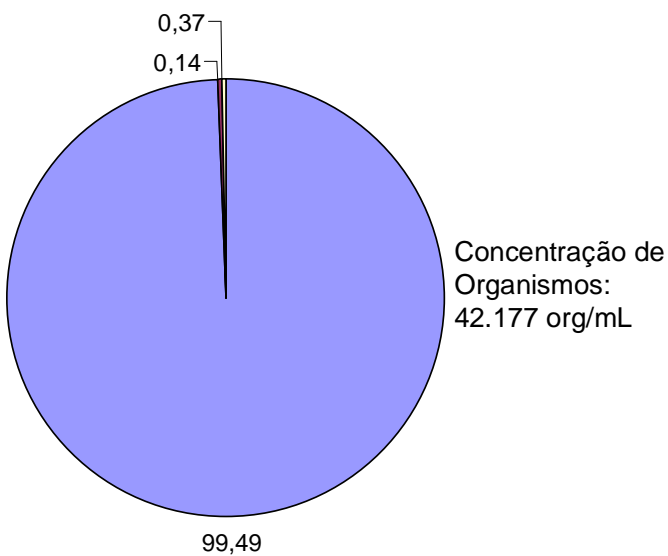

$\square$ Células de Microcystis $\square$ Colônias de Microcystis $\square$ Outros Organismos Fitoplanctônicos

Figura 5.14 - Contagem de organismos fitoplanctônicos da cultura preparada em laboratório, da água do resenvatório e da água de estudo 2 


\subsection{1 - Primeira Fase da Segunda Etapa}

Como foi preparada outra água para a realização dos ensaios restantes foram feitos alguns pré-ensaios de tratabilidade com dosagens de coagulante variando na faixa de 40 a $55 \mathrm{mg} / \mathrm{L}$ para escolha da dosagem de coagulante mais adequada para os ensaios posteriores. Os resultados desses ensaios estão apresentados na Tabela 5.3.

Tabela 5.3 - Ensaios simplificados de tratabilidade por coagulação/floculação seguidos de flotação com resultados de cor aparente e turbidez para a água de estudo 2.

\begin{tabular}{|c|c|c|c|c|c|}
\hline \multirow{3}{*}{$\begin{array}{c}\text { Dosagem de } \\
\text { Coagulante } \\
\text { (mg/L) }\end{array}$} & \multirow{3}{*}{$\begin{array}{c}\mathrm{pH} \text { de } \\
\text { Coagulação }\end{array}$} & \multicolumn{4}{|c|}{ Cor Aparente (uC) } \\
\hline & & \multicolumn{2}{|c|}{$\mathrm{V}=26 \mathrm{~cm} / \mathrm{min}$} & \multicolumn{2}{|c|}{$\mathrm{V}=13 \mathrm{~cm} / \mathrm{min}$} \\
\hline & & Cor Residual & \% Remoção & Cor Residual & \% Remoção \\
\hline 40 & 6,75 & 27 & 89,4 & 21 & 91,8 \\
\hline 45 & 6,46 & 20 & 92,2 & 15 & 94,1 \\
\hline 50 & 6,35 & 22 & 91,4 & 14 & 94,5 \\
\hline 55 & 6,35 & 39 & 84,7 & 14 & 94,5 \\
\hline \multirow{3}{*}{$\begin{array}{c}\text { Dosagem de } \\
\text { Coagulante } \\
\text { (mg/L) }\end{array}$} & \multirow{3}{*}{$\begin{array}{c}\text { pH de } \\
\text { Coagulação }\end{array}$} & \multicolumn{4}{|c|}{ Turbidez (uT) } \\
\hline & & \multicolumn{2}{|c|}{$\mathrm{V}=26 \mathrm{~cm} / \mathrm{min}$} & \multicolumn{2}{|c|}{$\mathrm{V}=13 \mathrm{~cm} / \mathrm{min}$} \\
\hline & & Tur. Residual & \% Remoção & Tur. Residual & \% Remoção \\
\hline 40 & 6,75 & 1,26 & 96,4 & 0,92 & 97,4 \\
\hline 45 & 6,46 & 0,97 & 97,2 & 0,78 & 97,8 \\
\hline 50 & 6,35 & 1,41 & 96,0 & 0,76 & 97,8 \\
\hline 55 & 6,35 & 3,23 & 90,8 & 0,71 & 98,0 \\
\hline
\end{tabular}

Os melhores resultados para os ensaios apresentados na tabela anterior foram obtidos com a adição de $45 \mathrm{mg} / \mathrm{L}$ de coagulante com melhor remoção de cor aparente e turbidez, para ambas velocidades de flotação. Assim, o efluente do ensaio com dosagem de coagulante de $45 \mathrm{mg} / \mathrm{L}$ foi caracterizado e os resultados estão apresentados na Tabela 5.4 . 
Tabela 5.4 - Caracterização da água após flotação com dosagem de coagulante 45 mg/L.

\begin{tabular}{lcc}
\hline \multicolumn{1}{c}{ Parâmetro } & Resultado & \% Remoção \\
\hline Sólidos Totais $(\mathrm{mg} / \mathrm{L})$ & 162 & 34,4 \\
Sólidos Suspensos Totais (mg/L) & 0,5 & 96,9 \\
Turbidez (uT) & 0,78 & 98,9 \\
Cor $(\mathrm{uC})$ & 15 & 97,5 \\
DQO $(\mathrm{mg} / \mathrm{L})$ & 47 & 49,5 \\
Microcistina $(\mu \mathrm{g} / \mathrm{L})$ & 10,39 & 28,1 \\
Clorofila-a $(\mu \mathrm{g} / \mathrm{L})$ & 2,2 & 91,8 \\
\hline
\end{tabular}

Em relação à remoção de microcistina o tratamento convencional coagulação/floculação seguido de flotação por ar dissolvido - teve eficiência de apenas $28,1 \%$ de remoção (residual de $10,39 \mu \mathrm{g} / \mathrm{L}$ ) confirmando as informações obtidas na literatura de baixa eficiência dos processos de separação após a coagulação/floculação. Os resultados deste trabalho mostram ter sido mais eficiente a remoção de microcistina por flotação que os obtidos por decantação em Ferreira (2004) - remoção de 14\%, com residual de 10,6 $\mu \mathrm{g} / \mathrm{L}$. Outro resultado que pode-se comparar com os obtidos pela autora supra citada é a remoção de microcistina apenas com a coagulação, ou seja, a influência do coagulante na remoção da toxina. A autora mostrou um resultado para água coagulada de $19,1 \%$ de remoção (residual de 9,98 $\mu \mathrm{g} / \mathrm{L}$ ). Nesta pesquisa obteve-se remoção de $30,2 \%$, com residual de $10,09 \mu \mathrm{g} / \mathrm{L}$.

A remoção de clorofila-a de $91,8 \%$ ficou muito próxima ao resultado obtido por Montiel \& Welté (1998) que obtiveram remoção de 93\% de clorofila-a com adição de 50 mg/L de Cloreto Férrico.

Reali \& Santos (1999) reportaram resultados de remoção de clorofila-a e turbidez em uma unidade piloto de flotação com taxa de aplicação superficial de 
$220 \mathrm{~m} /$ dia, a remoção de clorofila-a observada pelos autores foi de 88,4 a 98,2 \%, com residual entre 0,42 e $2,23 \mu \mathrm{g} / \mathrm{L}$; para turbidez a remoção foi de 82,5 a $86 \%$. Nesse trabalho foi utilizada uma instalação piloto, porém fazendo analogia mesmo que grosseira, de velocidade de flotação de $13 \mathrm{~cm} / \mathrm{min}(190 \mathrm{~m} / \mathrm{dia})$ em coluna de flotação alimentada por batelada com taxa de aplicação superficial aplicada em unidades de flotação com escoamento contínuo, verifica-se que tal valor 190m/dia - estaria proximo à $220 \mathrm{~m} /$ dia, mesma ordem de grandeza da utilizada pelos autores citados. Nesta presente pesquisa houve as seguintes remoções: de 91,8 \% para clorofila-a, muito próximo ao observado por aqueles autores; e a remoção de turbidez, no entanto, foi bem mais alta, 98,9 \%, não podendo esquecer que no caso da presente pesquisa foi utilizada unidade de flotação em escala de laboratório, além, é claro, de se tratar de outra água.

Nesta fase foram feitas contagens de organismos: para a cultura, para a água de reservatório e para a água de estudo 2 . Os resultados mostram que a cultura tinha $100 \%$ de células de Microcystis sp sem formação de colônias. Na água do reservatório, como era de se esperar, além de Microcystis, em ambas formas de células livres e colônias, também foram encontradas células de outros organismos pertencentes ao grupo das cianobactérias, como também dos grupos das diatomáceas, das clorofíceas e das criptofíceas. Na água de estudo por se tratar de uma mistura de cultura e água do reservatório foram encontrados organismos de vários dos grupos citados; aqueles presentes em pequeno número na água do reservatório não estavam presentes nas amostras levadas para contagem. 
Cabe aqui um comentário sobre o que diz o trabalho de Baker \& Fabbro (1999) sobre determinação de microcistina relacionada à contagem de organismos. Os autores que trabalharam com cultura de cianobactérias propuseram a adoção de $1 \mu \mathrm{g} / \mathrm{L}$ de microcistina para cada $6500 \mathrm{org} / \mathrm{mL}$ encontrados. A cultura usada neste estudo apresentou uma concentração de 38.030.633 org/mL e de microcistina de $350 \mu \mathrm{g} / \mathrm{L}$, uma diferença de $1672 \%$ para menos em relação ao referido pelos autores. Para a água do reservatório utilizada para preparo da água de estudo 2 a concentração de microcistina foi de $0,20 \mu \mathrm{g} / \mathrm{L}$ e a de microrganismos de 6.219 org $/ \mathrm{mL}$, diferença de $224 \%$. Para a água de estudo 2 nota-se uma diferença de 20 \% em relação ao que propõem os autores, com concentração de organismos e microcistina de, respectivamente, 41.960 org/mL e 14,45 $\mu \mathrm{g} / \mathrm{L}$. Ou seja, esse tipo de relação não pode ser feita já que há o risco de acidentes ocorrerem por má avaliação.

\subsection{2 - Segunda Fase da Segunda Etapa}

Para avaliar a influência do oxidante em relação à toxina estudada foram feitos ensaios com a água de estudo e aplicando-se as seguintes dosagens de oxidante $(1,0 ; 2,1 ; 6,0$ e $10,0 \mathrm{mg} / \mathrm{L})$ e tempo de contato de 30 minutos, sem tratamento na seqüência. Os resultados estão apresentados na Figura 5.15. 


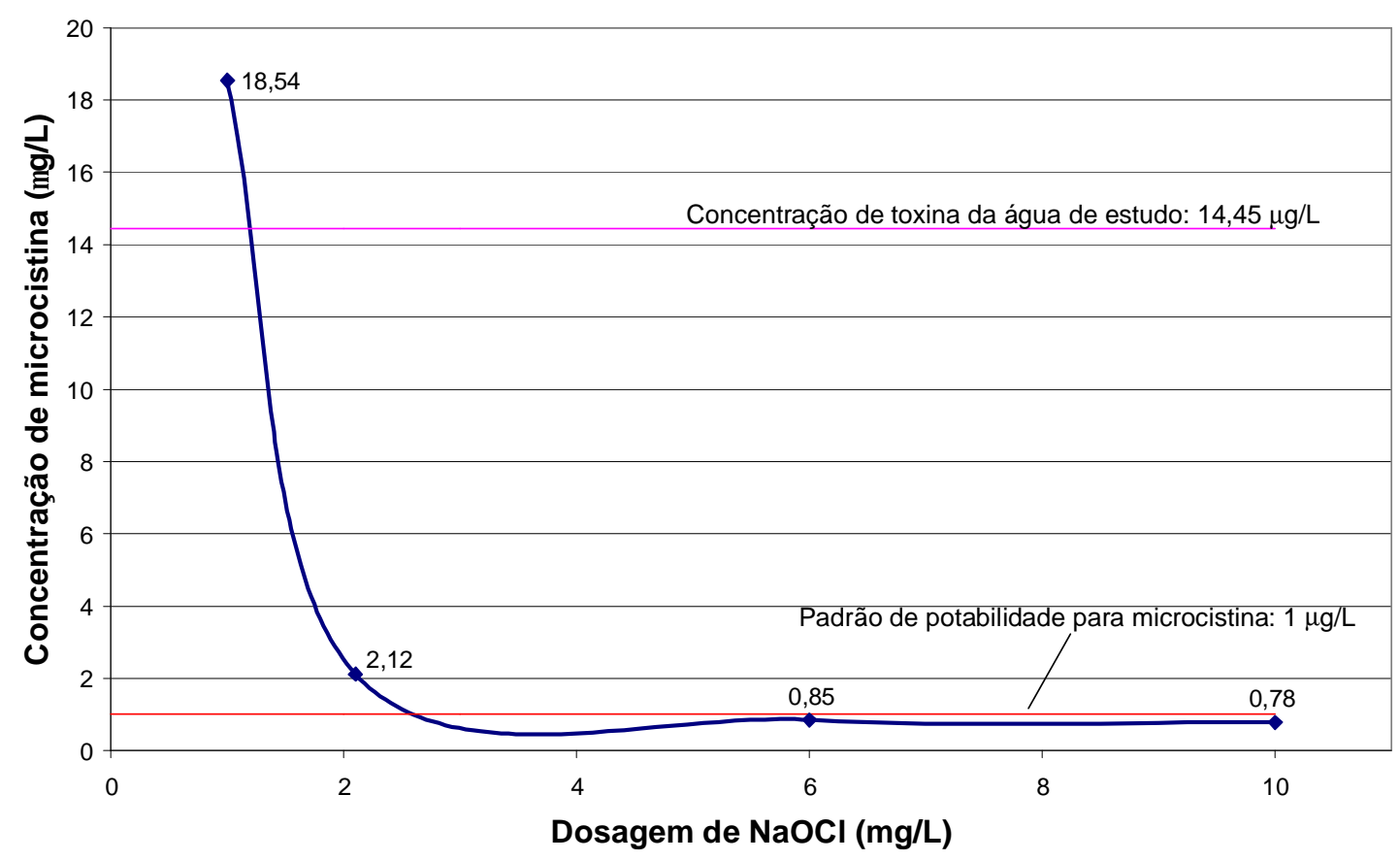

Figura 5.15 - Concentração de microcistina para ensaio de oxidação da água de estudo com tempo de contato do oxidante de 30 minutos.

Para a dosagem de $1 \mathrm{mg} / \mathrm{L}$ de hipoclorito de sódio houve aumento de concentração de microcistina de 28,3 \% sugerindo que o oxidante causou a lise ou estresse celular, o que acarretou a liberação de toxina para o meio. Com a dosagem de $2,1 \mathrm{mg} / \mathrm{L}$ a remoção de toxina foi de $85,3 \%$ e para dosagem de 6,0 $\mathrm{mg} / \mathrm{L}$ de $94,1 \%$. Esses resultados sugerem que o oxidante em dosagem suficiente oxida a toxina livre no meio, causa a lise ou estresse celular e oxida parte da toxina liberada após lise ou estresse. Para a água em questão, a aplicação de dosagens entre 3,0 e 4,0 mg/L de hipoclorito de sódio foi capaz de promover a oxidação da maior parte da microcistina presente na água, de forma a atender o 
limite máximo de concentração dessa substância preconizada pela Portaria 518 de 25 de março de 2004.

A concentração de trihalometanos foi determinada para algumas dosagens testadas de oxidante sem tratamento posterior. O tempo de contato variou de 20 minutos a 24 horas. Os resultados estão apresentados na Tabela 5.5 e na Figura 5.16.

Tabela 5.5 - Concentração de trihalometanos total ( $\mu \mathrm{g} / \mathrm{L})$ em função da dosagem de hipoclorito de sódio e do tempo de contato.

\begin{tabular}{ccc}
\hline \multirow{2}{*}{$\begin{array}{c}\text { Dosagem de } \\
\mathrm{NaOCl}(\mathrm{mg} / \mathrm{L})\end{array}$} & \multicolumn{2}{c}{ Concentração de THM $(\mu \mathrm{g} / \mathrm{L})$} \\
\cline { 2 - 3 } & $20 \mathrm{~min}$ & 24 horas \\
\hline 2 & 1,12 & $\mathrm{Nd}^{*}$ \\
3 & 1,27 & 7,1 \\
4 & 0,87 & 8,74 \\
5 & 0,61 & 8,59 \\
\hline
\end{tabular}

* Não determinado (perda de amostra)

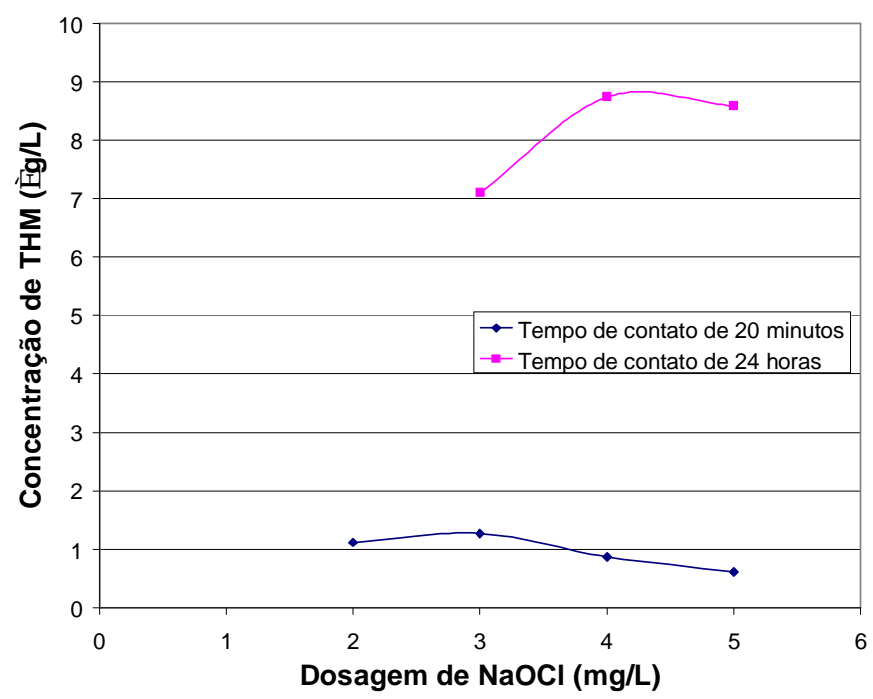

Figura 5.16 - Concentração de trihalometanos em relação à dosagem de hipoclorito de sódio e ao tempo de contato do oxidante 
Nota-se que a formação de trihalometanos esteve sempre abaixo do máximo permitido pela Portaria 518 de 25 de março de 2004, que é de $100 \mu \mathrm{g} / \mathrm{L}$, para todos os tempos e dosagens investigados. Como era de se esperar, para uma mesma dosagem de hipoclorito de sódio o tempo de contato de 20 minutos resultou em concentrações residuárias de THM bem menores que aquelas verificadas quando o tempo de contato foi igual a 24 horas. Tais resultados indicam uma ação persistente do cloro residual na geração de THM.

Nos resultados apresentados nas tabelas e discussões a seguir apenas o clorofórmio está relacionado porque para os outros tipos de trihalometanos os resultados ficaram abaixo do nível de detecção do método ou não estavam presentes. Os resultados completos estão apresentados no Anexo D.

\subsection{3 - Terceira Fase da Segunda Etapa}

Para os ensaios de flotação precedidos pelas etapas de pré-oxidação e coagulação/floculação, foi utilizada a dosagem de coagulante que proporcionou os melhores resultados nos ensaios sem pré-oxidação e também uma outra dosagem maior, ou seja, 45 e $50 \mathrm{mg} / \mathrm{L}$. As dosagens de oxidante foram determinadas pela curva de cloro residual livre. Os resultados estão apresentados na Tabela 5.6. 
Tabela 5.6 - Ensaio de de pré-oxidação, coagulação/floculação seguidos de flotação com resultados de cor aparente, turbidez e absorbância 254 nm, com adição de pré-oxidante 10 segundos antes da coagulação, para a água de estudo 2 .

\begin{tabular}{|c|c|c|c|c|c|c|}
\hline \multirow{3}{*}{$\begin{array}{c}\text { Dosagem de } \\
\text { Coagulante } \\
(\mathrm{mg} / \mathrm{L})\end{array}$} & \multirow{3}{*}{$\begin{array}{c}\mathrm{pH} \text { de } \\
\text { Coagulação }\end{array}$} & \multirow{3}{*}{$\begin{array}{c}\text { Dosagem de } \\
\text { Oxidante } \\
\text { (mg/L) }\end{array}$} & \multicolumn{4}{|c|}{ Cor Aparente (uC) } \\
\hline & & & \multicolumn{2}{|c|}{$\mathrm{V}=26 \mathrm{~cm} / \mathrm{min}$} & \multicolumn{2}{|c|}{$\mathrm{V}=13 \mathrm{~cm} / \mathrm{min}$} \\
\hline & & & Cor Residual & \% Remoção & Cor Residual & \% Remoção \\
\hline 45 & 6,35 & 2,1 & 22 & 91,5 & 16 & 93,6 \\
\hline 50 & 6,25 & 2,1 & 20 & 92,3 & 13 & 94,9 \\
\hline 45 & 6,46 & 6 & 34 & 86,8 & 24 & 90,6 \\
\hline 50 & 6,38 & 6 & 40 & 84,2 & 15 & 94,0 \\
\hline \multirow{3}{*}{$\begin{array}{c}\text { Dosagem de } \\
\text { Coagulante } \\
\text { (mg/L) }\end{array}$} & \multirow{3}{*}{$\begin{array}{c}\mathrm{pH} \text { de } \\
\text { Coagulação }\end{array}$} & Dosagem de & \multicolumn{4}{|c|}{ Turbidez (uT) } \\
\hline & & \multirow{2}{*}{$\begin{array}{l}\text { Oxidante } \\
\text { (mg/L) }\end{array}$} & \multicolumn{2}{|c|}{$\mathrm{V}=26 \mathrm{~cm} / \mathrm{min}$} & \multicolumn{2}{|c|}{$\mathrm{V}=13 \mathrm{~cm} / \mathrm{min}$} \\
\hline & & & Tur. Residual & \% Remoção & Tur. Residual & \% Remoção \\
\hline 45 & 6,35 & 2,1 & 1,08 & 96,9 & 0,49 & 98,6 \\
\hline 50 & 6,25 & 2,1 & 0,91 & 97,4 & 0,36 & 99,0 \\
\hline 45 & 6,46 & 6 & 2,26 & 93,6 & 1,00 & 97,1 \\
\hline 50 & 6,38 & 6 & 3,21 & 90,8 & 0,50 & 98,6 \\
\hline \multirow{2}{*}{$\begin{array}{c}\text { Dosagem de } \\
\text { Coagulante } \\
(\mathrm{mg} / \mathrm{L})\end{array}$} & \multirow{2}{*}{$\begin{array}{c}\text { pH de } \\
\text { Coagulação }\end{array}$} & \multirow{2}{*}{$\begin{array}{c}\text { Dosagem de } \\
\text { Oxidante } \\
\text { (mg/L) }\end{array}$} & \multicolumn{2}{|c|}{$\begin{array}{c}\text { Absorbância } 254 \mathrm{~nm} \\
\mathrm{~V}=13 \mathrm{~cm} / \mathrm{min}\end{array}$} & & \\
\hline & & & Residual & \% Remoção & & \\
\hline 45 & 6,35 & 2,1 & 0,080 & 51,5 & & \\
\hline 50 & 6,25 & 2,1 & 0,065 & 60,6 & & \\
\hline 45 & 6,46 & 6 & 0,098 & 40,6 & & \\
\hline 50 & 6,38 & 6 & 0,078 & 52,7 & & \\
\hline
\end{tabular}

Para ambas as dosagens de oxidante os melhores resultados de cor e turbidez foram obtidos quando a dosagem de cloreto férrico foi de $50 \mathrm{mg} / \mathrm{L}$. Apenas para a velocidade de $26 \mathrm{~cm} / \mathrm{min}$ a dosagem de $45 \mathrm{mg} / \mathrm{L}$ apresentou melhores resultados de cor e turbidez, mesmo assim foi pequena a diferença entre os valores. Na Tabela 5.7 estão apresentados os resultados para a caracterização das amostras oriundas de ensaios com pré-oxidação e na Figura 5.17 estão apresentados em gráficos os valores de clorofila-a, microcistina e THM clorofórmio. 
Tabela 5.7 - Caracterização das amostras após ensaio de flotação com pré-oxidação 10 segundos antes da coagulação ( $\left.\mathrm{V}_{\text {flot }}=13 \mathrm{~cm} / \mathrm{min}\right)$.

\begin{tabular}{cccccc}
\hline $\begin{array}{c}\text { Dosagem de } \\
\begin{array}{c}\text { Coagulante } \\
(\mathrm{mg} / \mathrm{L})\end{array}\end{array}$ & $\begin{array}{c}\text { Dosagem de } \\
\text { Oxidante } \\
(\mathrm{mg} / \mathrm{L})\end{array}$ & $\begin{array}{c}\text { Cor Aparente } \\
(\mathrm{uC})\end{array}$ & $\begin{array}{c}\text { Turbidez } \\
(\mathrm{uT})\end{array}$ & $\begin{array}{c}\text { Absorbância } \\
254 \mathrm{~nm}\end{array}$ & $\begin{array}{c}\text { DQO } \\
(\mathrm{mg} / \mathrm{L})\end{array}$ \\
\hline 45 & 2,1 & 16 & 0,49 & 0,080 & 10 \\
50 & 2,1 & 13 & 0,36 & 0,065 & 25 \\
45 & 6,0 & 24 & 1,00 & 0,098 & 15 \\
50 & 6,0 & 15 & 0,50 & 0,078 & 18 \\
\hline Dosagem de & Dosagem de & Clorofila-a & Microcistina & THM - & \\
Coagulante & Oxidante & $(\mu \mathrm{g} / \mathrm{L})$ & $(\mu \mathrm{g} / \mathrm{L})$ & $(\mu \mathrm{g} / \mathrm{L})$ & \\
$(\mathrm{mg} / \mathrm{L})$ & $(\mathrm{mg} / \mathrm{L})$ & 1,73 & 6,13 & $<2,0$ & \\
\hline 45 & 2,1 & 1,45 & 3,61 & $\mathrm{~N} \mathrm{~d} \mathrm{~d}^{*}$ & \\
50 & 2,1 & 1,79 & 1,08 & 8,54 & \\
45 & 6,0 & 1,93 & 0,82 & 11,23 & \\
50 & 6,0 & & & &
\end{tabular}

${ }^{*}$ Não determinado

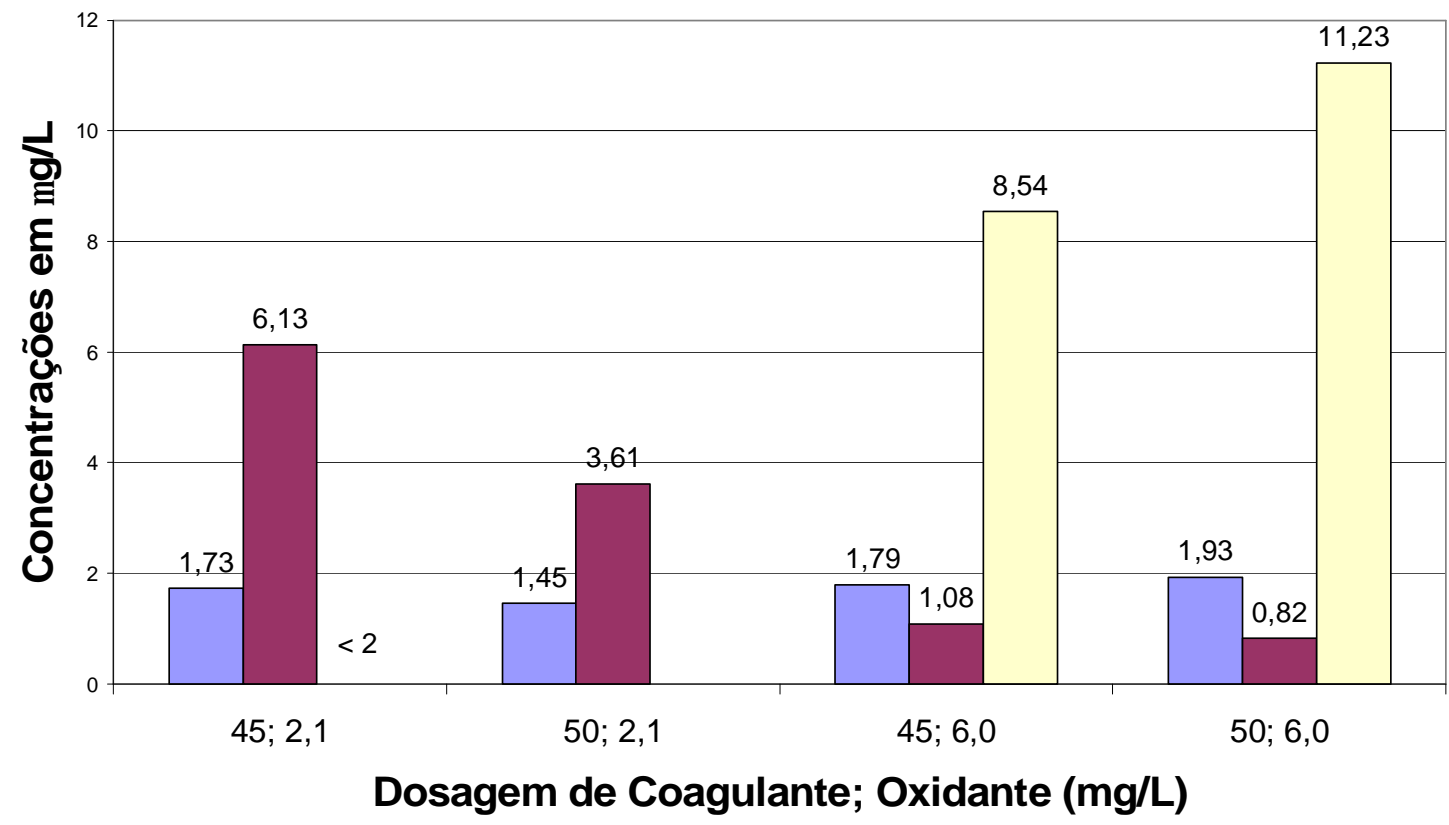

$\square$ Clorofila-a $\square$ Microcistina $\square$ THM-Clorofórmio

Figura 5.17 - Concentrações residuais de clorofila-a, microcistina e clorofórmio para dosagem de coagulante e oxidante indicadas com aplicação do oxidante $10 \mathrm{~s}$ antes da coagulação. 
Observando a Tabela 5.7 e a Figura 5.17, verifica-se que os demais parâmetros analisados seguiram o mesmo padrão, ou seja, as dosagem de 50 $\mathrm{mg} / \mathrm{L}$, foram mais eficientes, exceto pela DQO para a dosagem de $2,1 \mathrm{mg} / \mathrm{L}$ de oxidante e DQO, clorofila-a e THM - clorofómio para 6,0 mg/L. Observa-se que a microcistina atingiu o padrão de potabilidade para as dosagens de $50 \mathrm{mg} / \mathrm{L}$ e 6,1 $\mathrm{mg} / \mathrm{L}$ de coagulante e oxidante, respectivamente e ficou muito próximo quando utilizada dosagem de $45 \mathrm{mg} / \mathrm{L}$ de coagulante e $6,0 \mathrm{mg} / \mathrm{L}$ de oxidante. A eficiência de remoção de toxina pela oxidação aumentou com a dosagem de oxidante e também com a associação com o coagulante. Ou seja, os melhores resultados de oxidação da microcistina ocorreu quando foi aplicada a maior dosagem de coagulante estudada - $50 \mathrm{mg} / \mathrm{L}$ - associada à maior dosagem de $\mathrm{NaOCl}$ investigada, ou seja, 6,0 mg/L. Para esse caso a remoção de toxina foi de 94,3\%.

\subsection{4 - Quarta Fase da Segunda Etapa}

Para avaliar a influência do tempo de contato do oxidante com a água de estudo foram feitos outros ensaios com os melhores resultados obtidos nos ensaios anteriores para cada dosagem de oxidante utilizado. Os melhores resultados para ambas as dosagens de oxidante foram obtidos com adição de 50 $\mathrm{mg} / \mathrm{L}$ de coagulante. Foram, então, realizados ensaios com $50 \mathrm{mg} / \mathrm{L}$ de coagulante e dosagens de oxidante de 2,1 mg/L e 6,0 mg/L simulando a aplicação do oxidante na captação de água bruta. O tempo de contato de 90 minutos e as condições de 
mistura foram calculados como mostrado no Ítem 4.4.1. Os resultados obtidos estão apresentados na Tabela 5.8. Na Figura 5.18 é apresentado um gráfico com as concentrações residuais de clorofila-a, microcistina e THM - clorofórmio.

Tabela 5.8 - Caracterização das amostras após ensaio de flotação com pré-oxidação 90 minutos antes da coagulação.

\begin{tabular}{cccccc}
\hline $\begin{array}{c}\text { Dosagem de } \\
\text { Coagulante } \\
(\mathrm{mg} / \mathrm{L})\end{array}$ & $\begin{array}{c}\text { Dosagem de } \\
\text { Oxidante } \\
(\mathrm{mg} / \mathrm{L})\end{array}$ & $\begin{array}{c}\text { Cor Aparente } \\
(\mathrm{uC})\end{array}$ & $\begin{array}{c}\text { Turbidez } \\
(\mathrm{uT})\end{array}$ & $\begin{array}{c}\text { Absorbância } \\
254 \mathrm{~nm}\end{array}$ & $\begin{array}{c}\text { DQO } \\
(\mathrm{mg} / \mathrm{L})\end{array}$ \\
\hline 50 & 2,1 & 68 & 8,63 & 0,226 & 29 \\
50 & 6,0 & 62 & 6,40 & 0,202 & 33 \\
\hline $\begin{array}{c}\text { Dosagem de } \\
\text { Coagulante } \\
(\mathrm{mg} / \mathrm{L})\end{array}$ & $\begin{array}{c}\text { Dosagem de } \\
\text { Oxidante } \\
(\mathrm{mg} / \mathrm{L})\end{array}$ & $\begin{array}{c}\text { Clorofila-a } \\
(\mu \mathrm{g} / \mathrm{L})\end{array}$ & $\begin{array}{c}\text { Microcistina } \\
(\mu \mathrm{g} / \mathrm{L})\end{array}$ & $\begin{array}{c}\mathrm{THM}- \\
\text { clorofórmio } \\
(\mu \mathrm{g} / \mathrm{L})\end{array}$ & \\
\hline 50 & 2,1 & 1,45 & 4,21 & $<2,0$ & \\
50 & 6,0 & 2,90 & 2,40 & 6,44 \\
\hline
\end{tabular}

Com base nos resultados mostrados na Tabela 5.8, e comparando com os ensaios anteriores com aplicação de menor tempo de contato do $\mathrm{NaOCl}$ (Tabela 5.7), é possível constatar que o maior tempo de contato do oxidante com a água de estudo fez piorar as condições do efluente para as duas dosagens de coagulante nas dosagens de oxidante investigadas, em relação aos residuais cor aparente, turbidez, absorbância a 254 nm, DQO e microcistina. Para o trihalometano clorofórmio pode-se comparar apenas o valor com dosagem de coagulante de $50 \mathrm{mg} / \mathrm{L}$ e $6,0 \mathrm{mg} / \mathrm{L}$ de oxidante, pois com essas dosagens para 0 ensaio de tempo de contato de 10 segundos a amostra foi perdida. Para clorofórmio a concentração foi menor. 
Resultados para Dosagem de Coagulante de $50 \mathrm{mg} / \mathrm{L}$

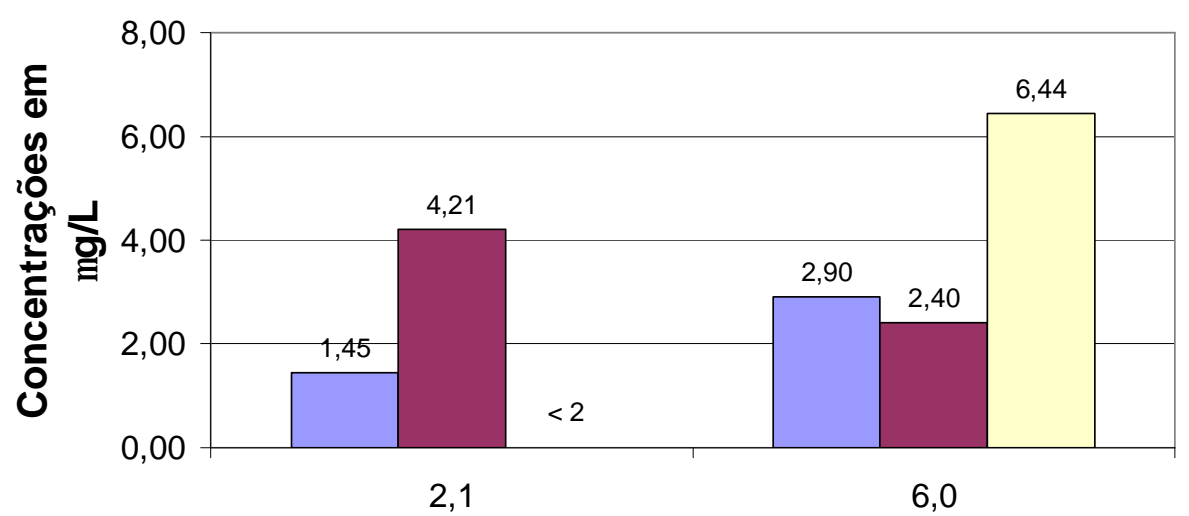

Dosagem de $\mathrm{NaOCl}$ (mg/L)

$\square$ Clorofila-a $\square$ Microcistina $\square$ THM-Clorofórmio

Figura 5.18 - Concentrações residuais de clorofila-a, microcistina e clorofórmio para as duas dosagens de oxidante estudadas e dosagem de coagulante de $50 \mathrm{mg} / \mathrm{L}$ (aplicação do oxidante 10 segundos antes da coagulação).

\section{4 - Resultados da Terceira Etapa}

\subsection{1 - Primeira Fase da Terceira Etapa}

O carvão ativado foi adicionado ao tratamento para remover o residual de toxina que não havia sido removida nas etapas anteriores. Em concentrações menores de toxina a demanda por carvão ativado é menor, caso que torna economicamente mais viável o uso desse material. A Tabela 5.9 e a Figura 5.19 mostram os resultados dos ensaios com pré-oxidação com tempo de contato de 10 segundos associados com a aplicação de carvão ativado em pó. 
Tabela 5.9 - Caracterização das amostras após ensaio de flotação com pré-oxidação 10 segundos antes da coagulação e adição de CAP.

\begin{tabular}{ccccccc}
\hline $\begin{array}{c}\text { Dosagem de } \\
\begin{array}{c}\text { Coagulante } \\
(\mathrm{mg} / \mathrm{L})\end{array}\end{array}$ & $\begin{array}{c}\text { Dosagem de } \\
\text { Oxidante } \\
(\mathrm{mg} / \mathrm{L})\end{array}$ & $\begin{array}{c}\text { Dosagem de } \\
\text { CAP } \\
(\mathrm{mg} / \mathrm{L})\end{array}$ & $\begin{array}{c}\text { Cor Aparente } \\
(\mathrm{uC})\end{array}$ & $\begin{array}{c}\text { Turbidez } \\
(\mathrm{uT})\end{array}$ & $\begin{array}{c}\text { Absorbância } \\
254 \mathrm{~nm}\end{array}$ & $\begin{array}{c}\text { DQO } \\
(\mathrm{mg} / \mathrm{L})\end{array}$ \\
\hline 45 & 2,1 & 20 & 40 & 3,23 & 0,144 & 29 \\
50 & 2,1 & 20 & 22 & 1,55 & 0,096 & 28 \\
45 & 6,0 & 20 & 49 & 4,59 & 0,168 & 37 \\
50 & 6,0 & 20 & 37 & 3,28 & 0,125 & 28 \\
\hline Dosagem de & Dosagem de & Dosagem de & Clorofila-a & Microcistina & THM - & clorofórmio \\
Coagulante & Oxidante & CAP & $(\mu \mathrm{g} / \mathrm{L})$ & $(\mu \mathrm{g} / \mathrm{L})$ & $(\mu \mathrm{g} / \mathrm{L})$ & 2,56 \\
$(\mathrm{mg} / \mathrm{L})$ & $(\mathrm{mg} / \mathrm{L})$ & $(\mathrm{mg} / \mathrm{L})$ & 2,11 & 2,89 & 9,43 & \\
\hline 45 & 2,1 & 20 & 2,11 & 1,63 & 6,11 & \\
50 & 2,1 & 20 & 1,16 & 0,33 & 5,88 \\
45 & 6,0 & 20 & 2,59 & 0,30 & \\
50 & 6,0 & 20 & 1,95 & &
\end{tabular}

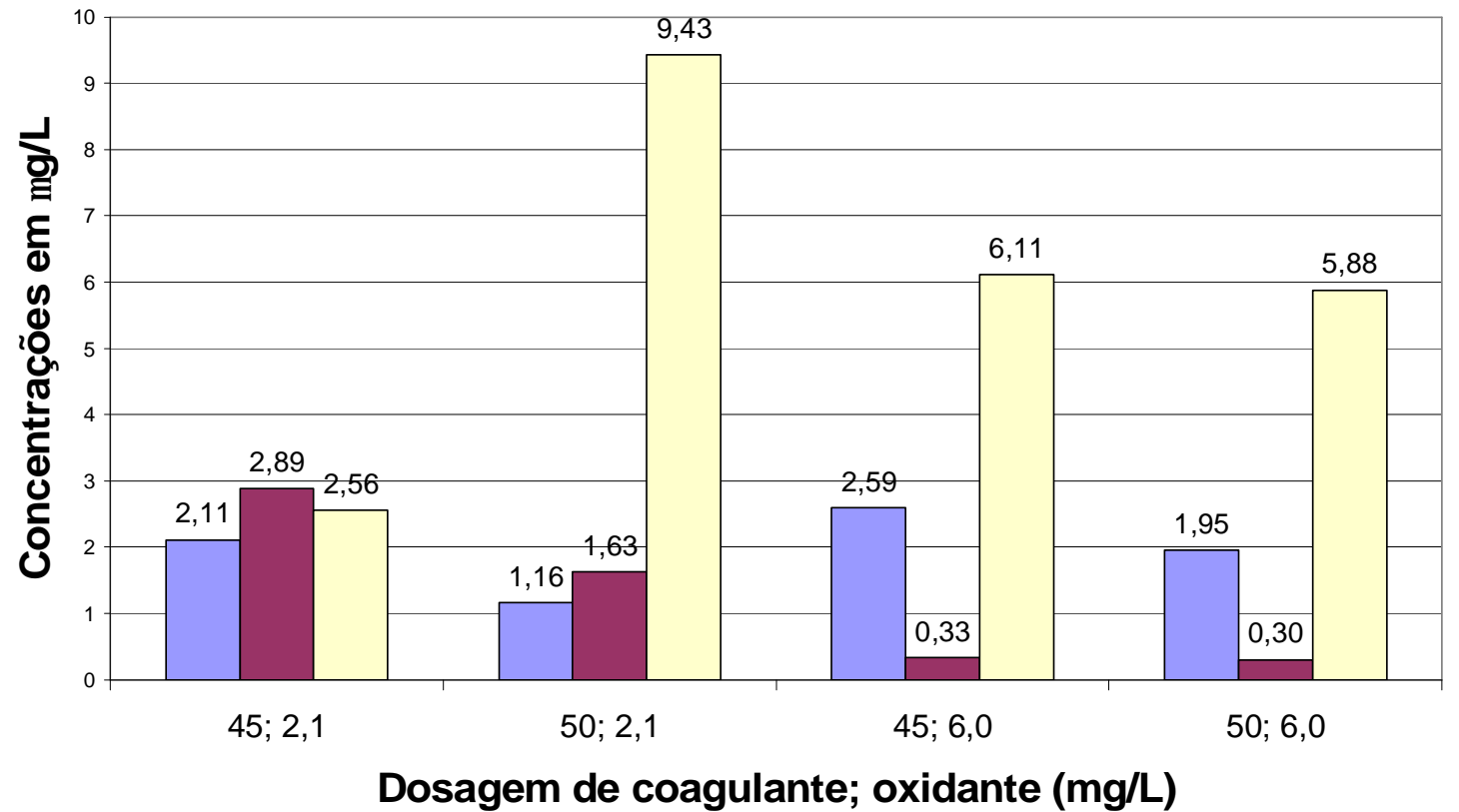

$\square$ Clorofila-a $\square$ Microcistina $\square$ THM-Clorofórmio

Figura 5.19 - Concentrações residuais de clorofila-a, microcistina e clorofórmio para dosagem de coagulante e oxidante indicadas com aplicação do oxidante $90 \mathrm{~min}$ antes da coagulação. 
Ferreira (2004) reportou que a concentração de carvão ativado necessária para remoção da toxina foi da ordem de $300 \mathrm{mg} / \mathrm{L}$, muito maior que as dosagens usuais em estações de tratamento. Possivelmente a autora teria usado um carvão sem as características necessárias para a remoção desse tipo de composto.

Com adição de 20 mg/L de carvão ativado houve melhora dos parâmetros avaliados em relação ao tratamento sem carvão para todas as dosagens de coagulante e oxidante estudadas. Comparando os resultados da Tabela 5.7 aos da Tabela 5.9 verifica-se que, em todos os casos houve remoção de toxina. A Tabela 5.10 e a Figura 5.20 apresentam o resumo desses resultados.

Tabela 5.10 - Comparação entre os resultados de pré-oxidação com $10 \mathrm{~s}$ de contato, coagulação/floculação e flotação por ar dissolvido sem e com a adição de carvão ativado em pó.

\begin{tabular}{ccccc}
\hline $\begin{array}{c}\text { Dosagem de } \\
\begin{array}{c}\text { Coagulante } \\
(\mathrm{mg} / \mathrm{L})\end{array}\end{array}$ & $\begin{array}{c}\text { Dosagem de } \\
\text { Oxidante } \\
(\mathrm{mg} / \mathrm{L})\end{array}$ & $\begin{array}{c}\text { Microcistina } \\
\text { Sem CAP } \\
(\mu \mathrm{g} / \mathrm{L})\end{array}$ & $\begin{array}{c}\text { Microcistina } \\
\text { Com CAP } \\
(\mu \mathrm{g} / \mathrm{L})\end{array}$ & $\begin{array}{c}\text { Melhora na } \\
\text { Remoção de } \\
\text { Toxina }(\%)\end{array}$ \\
\hline 45 & 2,1 & 6,13 & 2,89 & 52,9 \\
50 & 2,1 & 3,61 & 1,63 & 54,8 \\
45 & 6,0 & 1,08 & 0,33 & 69,4 \\
50 & 6,0 & 0,82 & 0,30 & 63,4 \\
\hline
\end{tabular}




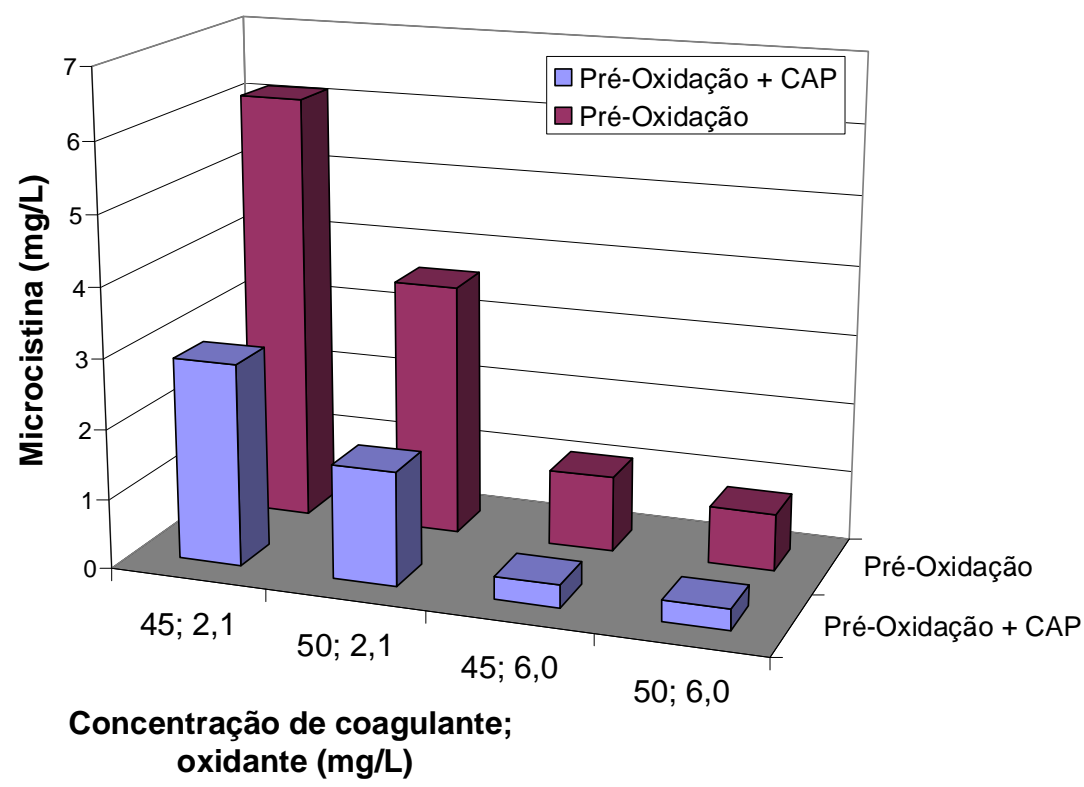

Figura 5.20 - Comparação dos resultados obtidos para microcistina somente com a préoxidação e para a associação de pré-oxidação e adição de CAP para o par de valores dosagem de coagulante e oxidante (aplicação de $\mathrm{NaOCl} 10 \mathrm{~s}$ antes da coagulação).

A adição de 20 mg/L de carvão teve eficiência de até 69,4 \% na remoção de toxina. O mesmo não ocorreu em relação aos outros parâmetros que, de modo geral, estiveram sempre mais elevados. Apenas em THM - clorofórmio para dosagem de $6,0 \mathrm{mg} / \mathrm{L}$ de oxidante também houve melhora em suas concentrações. Provavelmente esses resultados de cor, turbidez, absorbância a 264 nm e DQO foram influenciados pela presença de resíduos de carvão. 


\subsection{2 - Segunda Fase da Terceira Etapa}

Os resultados mostrados na Tabela 5.11 são provenientes de ensaios com pré-oxidação com tempo de contato de 90 minutos associados à aplicação de carvão ativado em pó. Na Figura 5.21 estão apresentados resultados residuais de clorofila-a, microcistina e THM - clorofórmio.

Tabela 5.11 - Caracterização das amostras após ensaio de flotação com pré-oxidação 90 minutos antes da coagulação e adição de CAP.

\begin{tabular}{|c|c|c|c|c|c|c|}
\hline $\begin{array}{c}\text { Dosagem de } \\
\text { Coagulante } \\
(\mathrm{mg} / \mathrm{L})\end{array}$ & $\begin{array}{c}\text { Dosagem de } \\
\text { Oxidante } \\
(\mathrm{mg} / \mathrm{L})\end{array}$ & $\begin{array}{c}\text { Dosagem de } \\
\text { CAP } \\
(\mathrm{mg} / \mathrm{L})\end{array}$ & $\begin{array}{c}\text { Cor Aparente } \\
\text { (uC) }\end{array}$ & $\begin{array}{l}\text { Turbidez } \\
\text { (uT) }\end{array}$ & $\begin{array}{c}\text { Absorbância } \\
264 \text { nm }\end{array}$ & $\begin{array}{c}\mathrm{DQO} \\
(\mathrm{mg} / \mathrm{L})\end{array}$ \\
\hline 50 & 2,1 & 20 & 79 & 8,81 & 0,225 & 37 \\
\hline 50 & 6,0 & 20 & 71 & 6,71 & 0,186 & 30 \\
\hline $\begin{array}{c}\text { Dosagem de } \\
\text { Coagulante } \\
(\mathrm{mg} / \mathrm{L})\end{array}$ & $\begin{array}{c}\text { Dosagem de } \\
\text { Oxidante } \\
(\mathrm{mg} / \mathrm{L})\end{array}$ & $\begin{array}{c}\text { Dosagem de } \\
\text { CAP } \\
(\mathrm{mg} / \mathrm{L})\end{array}$ & $\begin{array}{c}\text { Clorofila-a } \\
(\mu \mathrm{g} / \mathrm{L})\end{array}$ & $\begin{array}{c}\text { Microcistina } \\
(\mu \mathrm{g} / \mathrm{L})\end{array}$ & $\begin{array}{c}\text { THM - } \\
\text { clorofórmio } \\
(\mu \mathrm{g} / \mathrm{L})\end{array}$ & \\
\hline 50 & 2,1 & 20 & 2,32 & 3,12 & 3,47 & \\
\hline 50 & 6,0 & 20 & 2,08 & 2,67 & $<2,0$ & \\
\hline
\end{tabular}

Pode-se notar que, à exemplo do que ocorreu na quarta fase da segunda etapa de estudo, o oxidante agindo durante 90 minutos diminuiu a qualidade de alguns dos parâmetros. A concentração de microcistina teve melhora de 25,9 \% para a dosagem de oxidante de $2,1 \mathrm{mg} / \mathrm{L}$ e para a dosagem de $6,0 \mathrm{mg} / \mathrm{L}$ piora de 11,3 \%. Para o clorofórmio houve um comportamento contrário, pois para a dosagem de $2,1 \mathrm{mg} / \mathrm{L}$ de oxidante foi encontrada concentração maior do que sem CAP e para a dosagem de 6,0 mg/L a concentração ficou abaixo de 2,0 $\mu \mathrm{g} / \mathrm{L}$. 
Resultados para Dosagem de Coagulante de $50 \mathrm{mg} / \mathrm{L}$

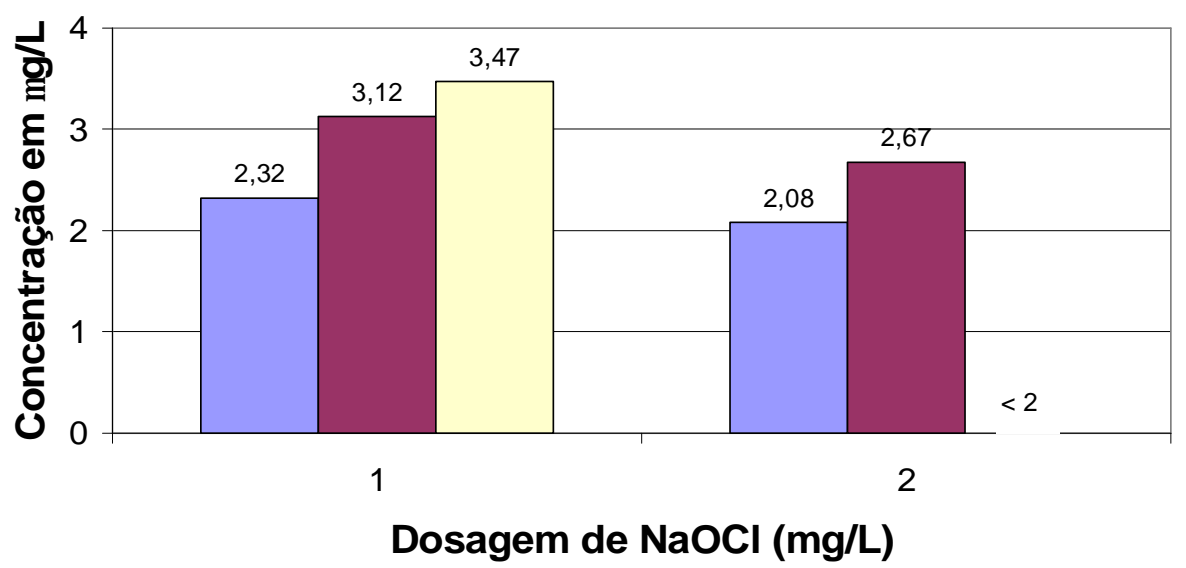

$\square$ Clorofila-a $\square$ Microcistina $\square$ THM-Clorofórmio

Figura 5.21 - Concentrações residuais de clorofila-a, microcistina e clorofórmio para as duas dosagens de oxidante estudadas e dosagem de coagulante de $50 \mathrm{mg} / \mathrm{L}$ (aplicação do oxidante 90 minutos antes da coagulação).

\section{5 - Resumo dos Resultados}

Nesse ítem estão apresentados em forma de esquema (Figura 5.22) os melhores resultados para todas as diferentes associação das técnicas de tratamento utilizadas ao longo da pesquisa. Os parâmetros apresentados para fins de comparação foram microcistina, clorofila-a, trihalometanos, cor e turbidez. 
Simulação de

um Sist. De

Trat. sem

Oxidação e

Adsorção

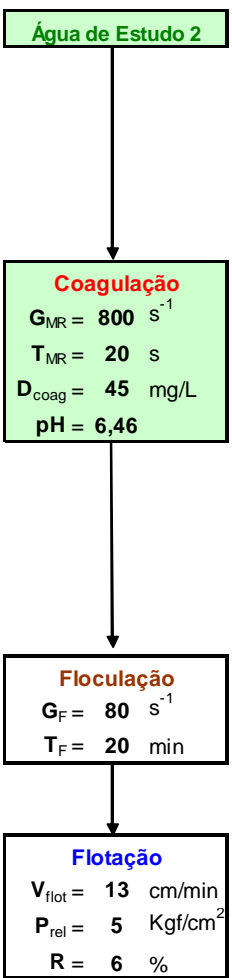

\section{Residuais após FAD}

microcistina $10,39 \mu \mathrm{g} / \mathrm{L}$

clorofila-a $\quad 2,2 \mu \mathrm{g} / \mathrm{L}$

THM N.d* $\mu \mathrm{g} / \mathrm{L}$

cor $15 \mathrm{UC}$

Turbidez 0,78 UT

* Não deteminado

\section{Simulação de um Sistema de Tratamento com Pré-Oxidação}

Sem Adsorção

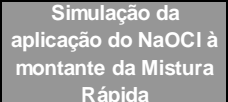

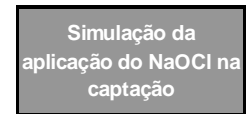

Água de Estudo 2
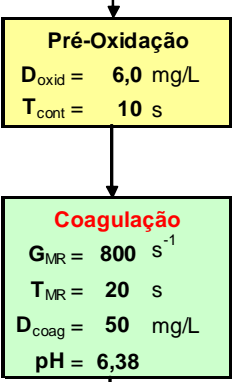

$\mathrm{pH}=6,38$

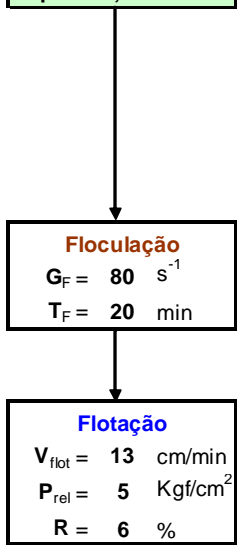

Residuais após FAD

microcistina $\quad 0,82 \mu \mathrm{g} / \mathrm{L}$

clorofila-a $1,93 \mu \mathrm{g} / \mathrm{L}$

THM $11,23 \mu \mathrm{g} / \mathrm{L}$

cor $15 \mathrm{uC}$

Turbidez $\quad 0,5$ uT

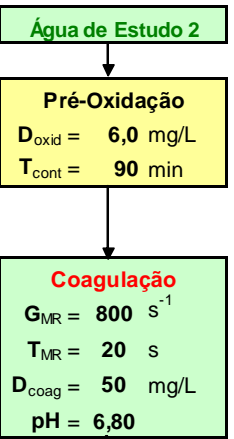

$\mathrm{pH}=6,80$

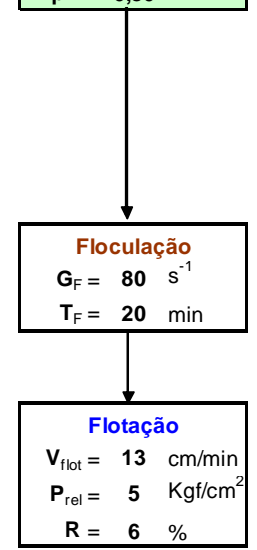

Residuais após FAD

microcistina $\quad 2,4 \mu \mathrm{g} / \mathrm{L}$

clorofila-a $\quad 2,9 \mu \mathrm{g} / \mathrm{L}$

THM $6,44 \mu \mathrm{g} / \mathrm{L}$

cor $62 \mathrm{uC}$

Turbidez $\quad 6,4$ UT
Com Adsorção após a Floculação

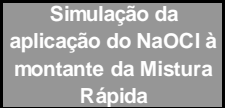

Simulação da

aplicação do $\mathrm{NaOCI}$

na captação

Água de Estudo 2
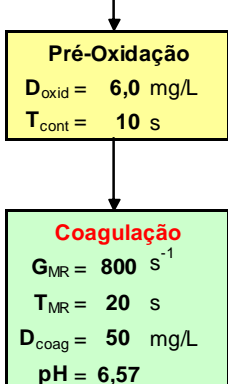

$\mathrm{pH}=6,57$

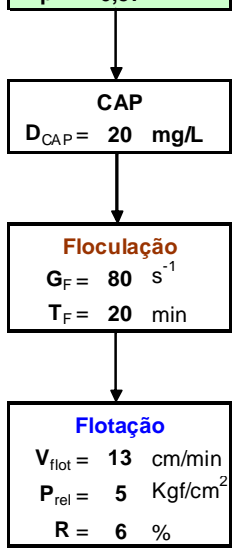

Água de Estudo 2

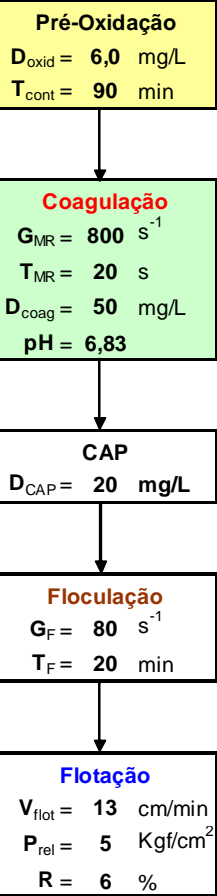

Residuais após FAD

Residuais após FAD

microcistina $2,67 \mu \mathrm{g} / \mathrm{L}$

clorofila-a $2,08 \mu \mathrm{g} / \mathrm{L}$

THM $<2 \mu \mathrm{g} / \mathrm{L}$

cor $61 \mathrm{uC}$

THM $5,88 \mu \mathrm{g} / \mathrm{L}$

cor $37 \mathrm{uC}$

Turbidez 3,28 uT

Turbidez 6,71 UT

Figura 5.22 - Esquema mostrando os melhores resultados obtidos em cada etapa de estudo. Concentrações iniciais: microcistina 14,45 $\mu \mathrm{g} / \mathrm{L}$; clorofila-a 26,9 $\mu \mathrm{g} / \mathrm{L}$; cor aparente 255 uC; turbidez 35,1 uT. 
Comparando os resultados apresentados na Figura 5.22 dos ensaios com pré-oxidação com aquele sem a pré-oxidação, ou seja, somente coagulação/floculação seguidos de flotação, esses resultados mostram que não foi possível remover em proporções significativas microcistina sem a adição de algum outro processo de tratamento de água.

A pré-oxidação foi eficiente na remoção de microcistina sem produzir concentração residual de trihalometanos superior ao determinado pela legislação brasileira. Comparando os dois tempos de contato do oxidante estudados antes da coagulação, o tempo de 10 segundos foi sempre mais eficiente, tanto nas situações em que não foi aplicado CAP quanto naquelas em que foi aplicado o referido adsomente. Ainda nota-se que somente atingiu-se o padrão de potabilidade nas ocasiões cujo tempo de aplicação do $\mathrm{NaOCl}$ foi de 10 segundos. Houve piora também nos resultados de cor e turbidez indicando possível ação prolongada do cloro residual na matéria orgânica presente na água. Como não foram realizados ensaios com tempos intermediários não se pode concluir que sempre para menores tempos de oxidação os resultados são melhores, mas é plausível inferir que com maior tempo de contato há maior probabilidade de ocorrer lise celular e conseqüente liberação de toxina intracelular para o meio líquido. É possível que para algum tempo intermediário esse resultado de remoção de microcistina por pré-oxidação seja ainda melhor, sendo recomendável investigação mais aprofundada sobre esse aspecto em estudos futuros.

Para as melhores condições de pré-oxidação - dosagem de 6,0 mg/L - o carvão ativado em pó utilizado com dosagem de $20 \mathrm{mg} / \mathrm{L}$ foi capaz de remover 
microcistina presente em níveis abaixo daquele estabelecido pelos padrões de potabilidade vigente $-1 \mu \mathrm{g} / \mathrm{L}$ - exceto quando se aplicou $6,0 \mathrm{mg} / \mathrm{L}$ de hipoclorito de sódio com 90 minutos de contato antes da coagulação, pois comparando o resultado de tratamento sem CAP de mesmo tempo de contato do oxidante o resultado de microcistina residual foi superior. Embora tenha se verificado ligeiro aumento nos residuais de cor aparente e turbidez do efluente do flotador nos ensaios em que foi aplicado $20 \mathrm{mg} / \mathrm{L}$ de CAP, tais residuais ainda podem ser considerados adequados tendo em vista que num sistema de tratamento de água real tem-se ainda a etapa de clarificação por filtração. As concentrações de trihalometanos foram menores quando aplicado CAP, sugerindo que também houve adsorção dessas substâncias pelo carvão.

Os resultados deste trabalho foram obtidos com equipamento em escala de laboratório por batelada, mas indicam que em equipamentos de escoamento contínuo os resultados de aplicação da pré-oxidação associada ou não à adsorção em carvão ativado podem ser satisfatórios no tratamento de águas contendo cianobactérias e microcistina.

Em que pesem as limitações inerentes a sistemas em escala de laboratório com alimentação em batelada, como aqueles utilizados na presente pesquisa, é possível que sejam feitas algumas considerações importantes de cunho prático.

Em estações convencionais onde o afluente possuir características semelhantes às da água de estudo desse trabalho há necessidade de freqüente controle dos níveis de microcistina da água que entra na estação, já que esse tipo de substância não sofre alterações significativas nas etapas de tratamento. 
Quando for constatada a presença da toxina em questão no efluente da estação de tratamento de água, a pré-oxidação com cloro pode ser uma alternativa para a remoção dessa toxina, desde que muita atenção seja dada à dosagem e ao tempo de reação do cloro associado ao ponto de aplicação do mesmo. Com base nos resultados dessa pesquisa a aplicação do oxidante logo à montante da unidade de mistura rápida seria preferível que em pontos situados também a montante, porém a distâncias maiores, como por exemplo junto à captação, cuja distância da estação de tratamento de água caracterize tempos da ordem de 90 minutos.

Para auxiliar o oxidante em relação à remoção de microcistina presente pode ser usado o carvão ativado em pó, em dosagem adequada, aplicado na saída da unidade de floculação. No que se refere à dosagem requerida, recomenda-se sempre a realização de ensaios de adsorção - como aqueles apresentados na presente dissertação - tendo em vista a influência marcante da qualidade da água e do tipo de carvão ativado na capacidade de adsorção de microcistina. 


\section{6 - CONCLUSÕES}

- A hipótese testada - que um sistema constituído por pré-oxidação, coagulação/floculação, seguidos de flotação por ar dissolvido seria eficiente no tratamento de água contendo cianobactérias e microcistina - revelou-se verdadeira, quando usadas dosagens de cloreto férrico e de hipoclorito de sódio de $50 \mathrm{mg} / \mathrm{L}$ e 6,0 mg/l (após o breakpoint), respectivamente, e com tempo de contato do oxidante antes da mistura rápida do coagulante de 10 segundos.

- A oxidação é eficiente na remoção de microcistina, mas não com tempos de contato muito grandes; os 90 minutos foram menos promissores que os 10 segundos ambos usados neste trabalho.

- Os resultados obtidos neste trabalho indicam que os processo e operações utilizados para a clarificação de água - coagulação/floculação e flotação apesar de muito eficientes para a remoção de algas em suspensão, não foram eficientes na remoção de microcistina, dissolvida na água; porém, a flotação associada a processos de oxidação e/ou adsorção em carvão ativado em pó, em dosagens e tempos de contato adequados, 
demostraram constituir sistemas eficientes para remoção de microcistina a níveis tais que satisfizeram os limites atualmente exigidos pela legislação.

- O carvão ativado em pó estudado e aplicado depois da coagulação com dosagem de $20 \mathrm{mg} / \mathrm{L}$ foi bastante eficiente na remoção de microcistina, com remoção de até $69,4 \%$ quando utilizados $45 \mathrm{mg} / \mathrm{L}$ de coagulante e 6,0 $\mathrm{mg} / \mathrm{L}$ de oxidante, desde que aplicado 10 segundos antes da mistura rápida do coagulante.

\section{RECOMENDAÇÕES}

- Estudar tempos de contato do oxidante, antes da mistura rápida do coagulante, intermediários aos utilizados nessa pesquisa - 10 segundos a 90 minutos.

- Realizar estudo utilizando sistema de tratamento em escala piloto com etapas de pré-oxidação, coagulação/floculação e flotação para comprovar os resultados apresentados neste trabalho e aprofundar o conhecimento acerca desse assunto.

- Testar a ação de outros oxidantes em relação à remoção de microcistina. 


\section{7 - REFERÊNCIAS BIBLIOGRÁFICAS}

ANDERSON, W. B.; MAYFIELD, C. I.; DIXON, D. G. \& HUCK, P. M. (2003). Endotoxin Inactivation by Selected Drinking Water Treatment Oxidants. Water Research, n. 37, p. $4553-4556$.

AGUJARO, L. F. \& ISAAC, R. L. (2003). $22^{\circ}$ Congresso Brasileiro de Engenharia Sanitária e Ambiental.

AMARAL E SILVA, C. C. (1972). Poluição das Águas e Eutrofização. Tese (Doutorado). Departamento de Saúde Ambiental, Faculdade de Saúde Pública, Universidade de São Paulo, 69p.

AMERICAN WATER WORKS ASSOCIATION (1991). AWWA Standard for Granular Activated Carbon. 6666 West Avenue, Denver, Colorado.

ANDERSON, W. B.; MAYFIELD, C. I.; DIXON, D. G. \& HUCK, P. M. (2003). Endotoxin Inactivation by Selected Drinking Water Treatment Oxidants. Water Research, n. 37, p. $4553-4556$.

ANSELME, C.; DUGUeT, P.; MALLEVIALLE, J. \& SUFFET, I. H. (1992). Ozonation of Organics Compounds Causing Taste and Odor Problems. In: MALLEVIALLE, J.; SUFFET, I. H. \& CHAN, U. S. Influence and Removal fo Organics in Drinking Water. Lewis Publishers, Mexico.

ARDIZZONE, S.; GABRIELLI, G. \& LAZZARI, P. (1993). Adsorption of Methilene Blue at Solid/Liquid and Water/Air Interfaces. Colloids and Surfaces A: Physicochemical and Enginnering Aspects, 76, p. 149-157.

ASTM D 4607 (1994). Standard Test Method for determination of lodine Number of Activated Carbon. American Society for Testing and Materials, USA.

AZEVEDO, S. M. F. O.; CARMICHAEL, W. W.; JOCHIMSEN, E. M.; RINEHART, K. L.; LAU, S; SHAW, G. R. \& EAGLESHAM, G. K. (2002). Human Intoxication by Microcystins During Renal Dialisis Treatment in Caruaru - Brazil. Toxicology, 181182, p. 441-446.

BAKER, P. D. \& FABBRO, L. D. (1999). A Guide to Identification of Common Blue-Green Algae in Australias Freshwaters. Cooperative Researsh Centre for Freshwater Ecology, Albury. 
BARTON, S. S. (1987). The Adsorption of Methylene Blue by Active Carbon. Carbon, v. 25 , p. 343-350.

BRASIL, MINISTERIO DA SAÚDE (2003). Norma de Qualidade de Água para Consumo Humano - Portaria 518. D.O.U. 26/03/2004.

CALIJURI, M. C.; SANTOS, A. C. A. \& JATI, S. (2002). Temporal Changes in the Phytoplankton Community Structure in a Tropical na Eutrophic Reservoir (Barra Bonita, SP - Brazil). Journal of Plankton Research, v. 24, n. 7, p. 617-634.

CAMPOS, J. R. (1994). Alternativas para Tratamento de Esgotos e Pré-Tratamento de Águas para Abastecimento. Ed. Consórcio Intermunicipal das Bacias dos Rios Piracicaba e Capivari, Americana-SP, 67p.

CHARMICHAEL, W. W. (1992). A Status Report on Planktonic Cyanobacteria (blue-green algae) and their toxins. EPA / 600 / R-92 / 079.

CHARMICHAEL, W. W. (1994). The Toxins of Cyanobacteria. Scientific American. 270(1) pp. 78-86.

CHEN, Y. M.; LIU, J. C. \& JU, Y. H. (1998). Flotation Removal of Algae from Water. Colloids and Surfaces B: Biointerfaces, v. 12, p. 49-55.

CHORUS, I. e BARTRAM, J. (1999). Toxic Cyanobacteria in Water. E \& FN Spon, Londres, $416 \mathrm{p}$.

COSTANZI, R. N. (2000). Estudo de Tratamento Físico-Químico - Flotação por Ar Dissolvido, Sedimentaco, Microfiltracao e Ozonizacao - do Efluente de Uma Fabrica de Papel para Imprimr Visando o Reúso de Água. São Carlos, Dissertação (Mestrado), Departamento de Hidráulica e Saneamento, Escola de Engenharia de São Carlos, Universidade de São Paulo, 277p.

DANIEL, L. A. - coordenador - (2001). Processos de Desinfecção e Desinfetantes Alternativos na Produção de Água Potável. Rio de Janeiro, RiMa, ABES.

DI BERNARDO, L. (1993). Métodos e Tecnicas de Tratamento de Água. Rio de Janeiro, ABES, v. 1, 450p.

DI BERNARDO, L. (1995). Algas e suas Influências na Qualidade das Águas e nas Tecnologias de Tratamento. Rio de Janeiro, ABES, 127p. 
DOMBROSKI, S. A. G. (1996). Influência da Floculação na Eficiência de Flotação por Ar Dissolvido Aplicada ao Tratamento de Água de Abastecimento. São Carlos, Dissertação (Mestrado), Universidade de São Paulo - Escola de Engenharia de São Carlos - Departamento de Hidráulica e Saneamento, 195p.

DUARTE, R. G. (1982). Eutrofização da Represa do Lobo: Observações Sobre Fatores que Contribuem para a Eutrofização de Represas em Climas Tropicais. Tese (Doutorado), Departamento de Saúde Ambiental, Faculdade de Saúde Pública, Universidade de São Paulo, 269p.

EB-2133 (1991). Carvão Ativado Pulverizado. ABNT - Associação Brasileira de Normas Técnicas, Brasil.

EDZWALD, J. K. (1995). Principles an Applications of Dissolved Air Flotation. In: IVES, K. \& BERNHART, H. J. (eds.). Flotation Processes in Water and Sludge Treatment. Water Science \& Technology, Gret Britain, v. 31, n. 3-4, p.1-23.

EDZWALD, J. K. \& WINGLER, B. J. (1990). Chemical and Physical Aspects of DissolvedAir Flotation for Removal of Algae. Aqua, v. 39, p. 24-35.

ESTEVES, F.A. (1988). Fundamentos de Limnologia. Editora Interciência - FINEP. Rio de Janeiro. 602p.

FALCO, P. B. (2000). Distribuição Espacial e Temporal da Comunidade Fitoplanctônica e das Variáveis Ecológicas no Reservatório de Saolto Grande (Americana -SP) em Duas Épocas do Ano. Dissertação (Mestrado), Universidade de São Paulo - Escola de Engenharia de São Carlos - Departamento de Hidráulica e Saneamento, 120p.

FERREIRA, L. P. H. (2004). Remoção da Biomassa Algal e Determinacao da Concentração de Microcistina em Ensaios de Coagulação, Sedimentação, Filtração e Adsorcao com Emprego do Método ELISA. Dissertação (Mestrado), Universidade de São Paulo - Escola de Engenharia de São Carlos - Departamento de Hidráulica e Saneamento, 109p.

GAETE, V. et al (1994). Inhibitory Effects of Microcystis Aeruginosa Toxin on Ion Pumps of the Gill of Freshwater Fish.. Toxicon, 32: 121-127.

HAUTMAN, D. P. \& MUNCH, D. J. (1997). Development of U.S. EPA Method 55.1. Journal of Chromatographic Science. V. 35, p 221-231. 
HITZFELD, B.C.; HOGER, S.J.; DIETRICH, D.R. (2000). Cyanobacterial Toxins: Removal During Drinking Water Treatment and Human Risk Assessment. Environ. Health Perspect. 108, 113-122.

HOEK, C. VAN DEN; MANN, D. G.; JAHNS, H. M. (1995). Algae, an Introduction to Phycology. Cambridge University press, Cambridge, $623 \mathrm{p}$.

HUDREY, S.; BURCH, M.; DRIKAS, M. \& GREGORY, R.. Remedial Measures. In: CHORUS, I. \& BARTRAM, J. (1999) Toxic Cyanobacteria in Water. London: E\&FN Spon.

HUTCHINSON, G. E. (1969). Eutrophication: Past and Present. In: NATIONAL ACADEMY OF SCIENCE, ed. Eutrophication: Causes, Consequences and Corretives, 3 ed. Washington, p. 17-26.

IMAMURA, K.; IKEDA, E.; NAGAYASU, T.; SAKIYAMA, T. \& NAKANISHI, K. (2002). Adsorption Behavior of Methylene Blue and Its Congeners on a Stainless Steel Surface. Journal of Colloid and Interface Science, 245, p. 50-57.

LACERDA, M.R.S. (1997). A Influência do pH de Coagulação e do Tempo de Floculação na Flotação por Ar Dissolvido no Tratamento de Águas com Baixa Turbidez e Presença de Microalgas. Dissertação de Mestrado. Departamento de Engenharia Civil, Universidade de Brasília.

LAGE FILHO, F. A. \& FERREIRA FILHO, S. S. (1997). Estudo Piloto de Tratabilidade de Águas Eutrofizadas: Efeitos da Pré-Oxidação com Cloro Livre no Processo de Filtração. In: Anais do $19^{\circ}$ Congresso Brasileiro de Engenharia Sanitária e Ambiental.

LEHR, J. H. (1991). Granular Activated Carbon (GAC): Everyone Knows of It,Few Understand lt. Ground Water Monitoring Review, n. 4, p. 4-6.

LORENZI, A. S. (2004). Abordagens para Detectar Cianobacterias e seus Genotipos Produtores de Microcistinas Presentes nas Represas Billings e Guarapiranga, São Paulo, Brasil. Piracicaba, Dissertação (Mestrado), Universidade de São Paulo, Escola Superior de Agronomia Luiz de Queiroz, Centro de Energia Nuclear na Agricultura.

MA, J. \& LIU, W. (2001). Effectiveness and Mechanism of Potassium Ferrate (VI) Preoxidation for Algae Removal by Coagulation. Water Research, n. 36, p. 871-878. 
MARSH, H.; HEINZ, E. A. \& RODRÍGUEZ REINOSO, F. (1997). Introduction to Carbon Technology. University of Alicante, Spain.

MATTHIENSEN, A. (1996). Ocorrência, Distribuição e Toxicidade de Cianobactérias no Estuário da Lagoa dos Patos - RS. Revista brasileira de Biologia, 59: 2204-2209.

METCALF \& EDDY (1991). Wastewater Engineering - Treatment, Disposal and Reuse. 3.ed., New York, McGraw-Hill, Inc., 1334p.

MINISTÉRIO DA SAÚDE: Fundação Nacional de Saúde (2003). Cianobactérias Tóxicas na Água Para Consumo Humano na Saúde Pública e Processos de Remoção em Água Para Consumo Humano. Brasília. 56 p.

MONTIEL, A. \& WELTÉ, B. (1998). Preozonation Coupled with Flotation Filtration: Successful Removal of Algae. Water Science Technology, v. 37, n. 2, p. 65-73.

NBR 12216 (1992). Projeto de Estação de Abastecimento de Água para Abastecimento Público. ABNT - Associação Brasileira de Normas Técnicas, Brasil.

NICHOLSON, B. C.; ROSITANO, J. \& BURCH, M D. (1994). Destruction of Cyanobacterial Peptide Hepatotoxins by Chlorine and Choramine. Water Research n. 28, pp 1297-1303.

NUSH, E. A. (1980). Comparaison os Different Methods for Chrlorophyll-a and Pheopigment Determination. Arch. Hydrobiol. Bech. Stuttgart, v. 14, p. 14-36.

PADUA, H. B. (2002). Cianotoxinas e Outras Intrigantes Ocorrências em Criações de Organismos Aquáticos. 18p. Disponível em: www.serrano.neves.nom.br/cgd/010401/01041032.pdf (acessado em 30/09/2004).

PENDLETON, P.; SCHUMANN, R. \& WONG, S. H. (2001). Microcystin-LR Adsorption by Activated Carbon. Journal of Colloid and Interface Science, 240, p. 1-8.

POLLARD, S. J. T.; FOWLER, G. D.; SOLLARS, C. J. \& PERRY, R. (1992). Low-Cost Adsorbents for Water and Wastewater Treatment: A Review. The Science of the Total Environment , 116, p. 31-52.

REALI, M.A.P. (1991). Concepção e Avaliação de um Sistema Compacto para Tratamento de Águas de Abastecimento Utilizando o Processo de Flotação por As Dissolvido e Filtração com Taxa Declinante. Tese (Doutorado). Escola de Engenharia de São Carlos - Universidade de São Paulo. 
REALI, M.A.P. \& GIANOTTI, E.P. (1993). Remoção de Algas por Flotação: Testes de Laboratório. Congresso Brasileiro de Engenharia Sanitária e Ambiental, 17, Natal, 1993. Anais v. 2, Natal, ABES. P. 229-242.

REALI, M. A. P. \& SANTOS, S. P. (1999). Emprego de uma Unidade de Flotação de Alta Taxa com Escoamento Vertical para Remoção de Algas de Águas para Abastecimento. Engenharia e Arquitetura - Caderno de Engenharia Sanitária e Ambiental - vol. 1, n. 1 .

REYNOLDS, C.S. (1987). The Ecology of Freshwater Phytoplancton.Cambridge University Press, New York - USA.

SANT'ANNA, C. L.\& AZEVEDO, M. T. P. (2000). Contibution to Knowledge of Potentially Toxic Cyanobacteria from Brazil. Nova Hedwiia 71 (3-4), p. 359-385.

SANTOS, S.P. (1997). Estudos de Uma Unidade de Flotação por Ar Dissolvido com Escoamento Vertical entre Placas, Aplicada à Remoção de Algas em Águas de Abastecimento. São Carlos. Dissertação (Mestrado), Universidade de São Paulo Escola de Engenharia de São Carlos - Departamento e Hidráulica e Saneamento.

SANTOS, S.P. \& REALI, M.A.P. (1999). Emprego de uma Unidade de Flotação de Alta Taxa com Escoamento Vertical Para Remoção de Algas de Águas Para Abastecimento. Engenharia e Cultura - Caderno de Engenharia Sanitária e Ambiental - vol. 1, N. 1, Jan./Mar. pp. 37-45.

STANDARDS Methods for the Examination of Water and Wastewater (1998). $20^{\text {th }}$ edn. Washington, DC: American Health Association, American Water Works Association (AWWA), Water Environments Federation.

SMISEK, M \& CERNY, S. (1970). Active Carbon - Manufacture, Proprieties and Applications. Elsevier Publishing Company, New Yok.

TAVARES, L. H. S. \& ROCHA, O. (2003). Produção de Plâncton (Fitoplâncton e Zooplâncton) para Alimentação de Organismos Aquáticos. RiMa, São Carlos, 106p.

TSUJI, K.; WATANUKI, T.; KONDO, F.; WATANABE, M. F.; NAKAZAWA, H.; SUZUKI, M.; UCHIDA, H. \& HARADA, K. I. (1997). Stability of Microcistins from Cyanobacteria-IV. Effect of Chlorination on Decomposition. Toxicon, vol 35, pp 10331041.

WATER ENVIRONMENT FEDERATION (1996). Wastewater Desinfection: Manual of Practice FD - 10. Alexandria VA, USA, 29p. 
WHITTON, B.A. \& POTTS, M.. The Ecology of Cyanobacteria. London, Kluwer Academic Publishers

WHO (1996). Guidelines for Drinking Water Quality, Volume 2, Health Criteria and Other Supporting Information. World Heath Organization, Geneva, 973p.

WU, F. C.; TSENG, R. L. \& JUANG, R. S. (1999). Pore Structure and Adsorption Performance of the Carbons Prepared from Plum Kernels. Journal of Hazardous Materials, B69, p. 287-302. 


\section{ANEXO A}

Tabelas apresentando todos os resultados, para ensaios de tratabilidade da água de estudo 1, de cor aparente e turbidez para as dosagens de coagulante e velocidades de flotação utilizadas e também as quantidade de acidificante e alcalinizante usados. 


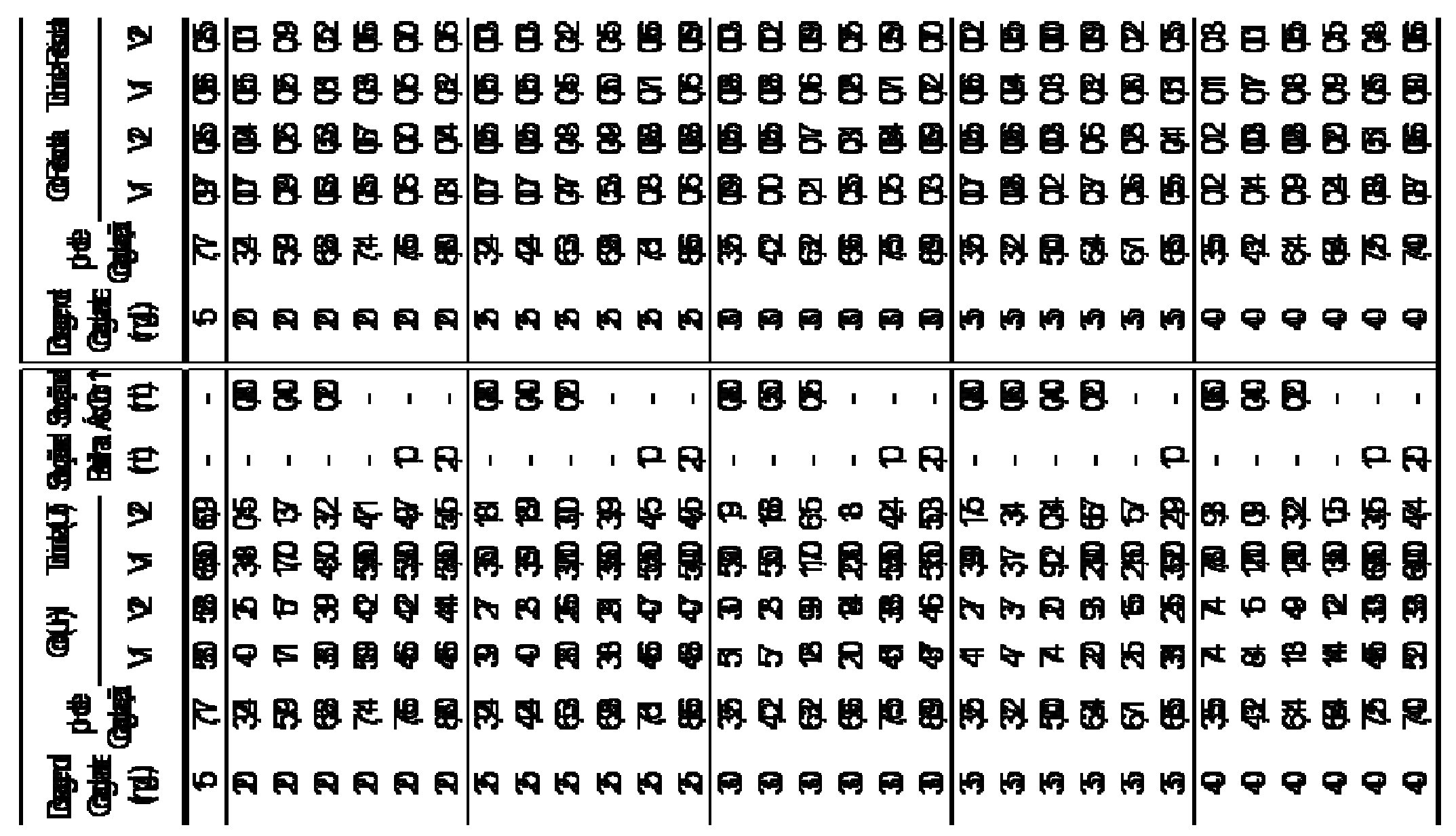




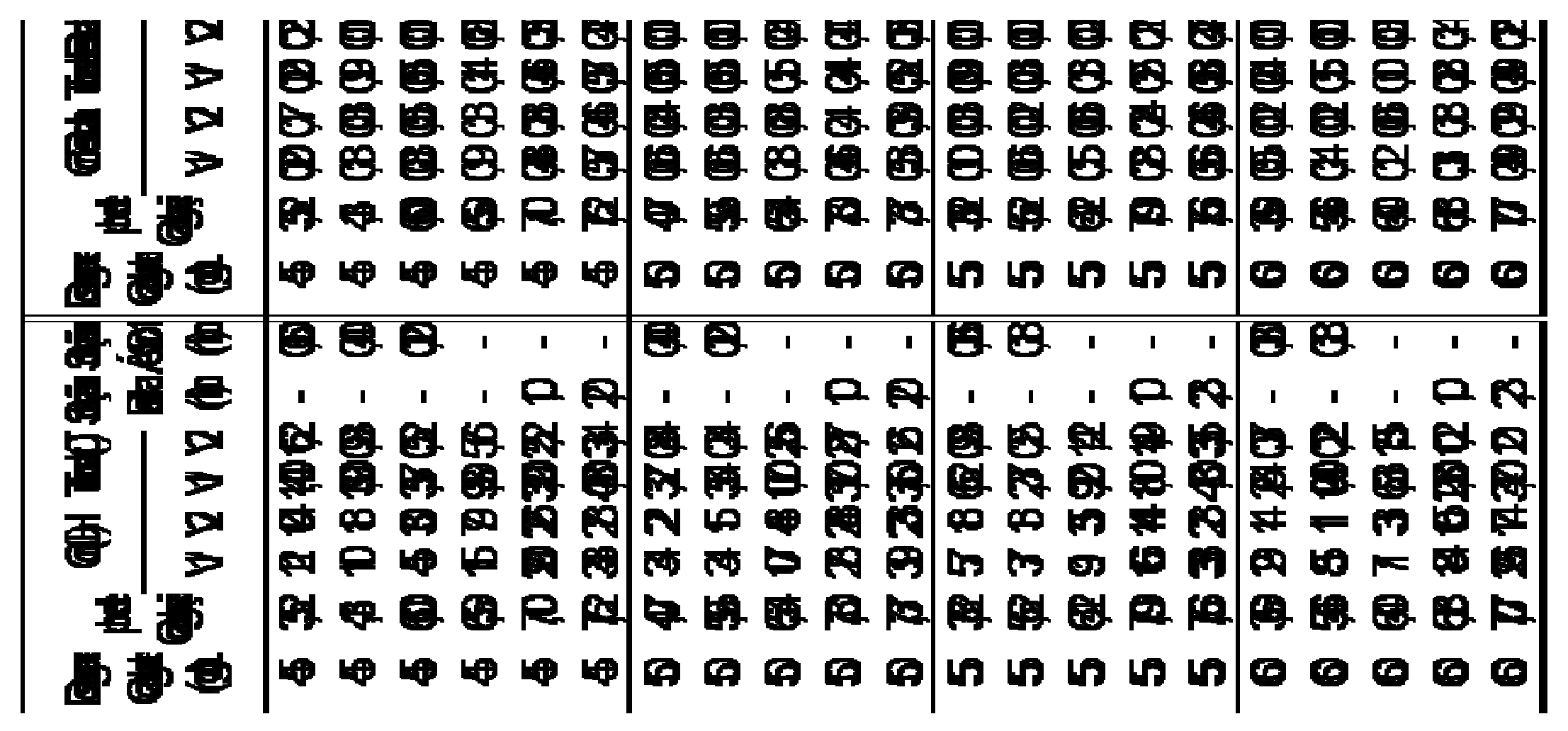




\section{ANEXO B}

Tabela apresentando todos os resultados de cor aparente e turbidez residual para ensaios de tratabilidade, para a água de estudo 1, aplicando préoxidação, coagulação/floculação e flotação pro ar dissolvido. 


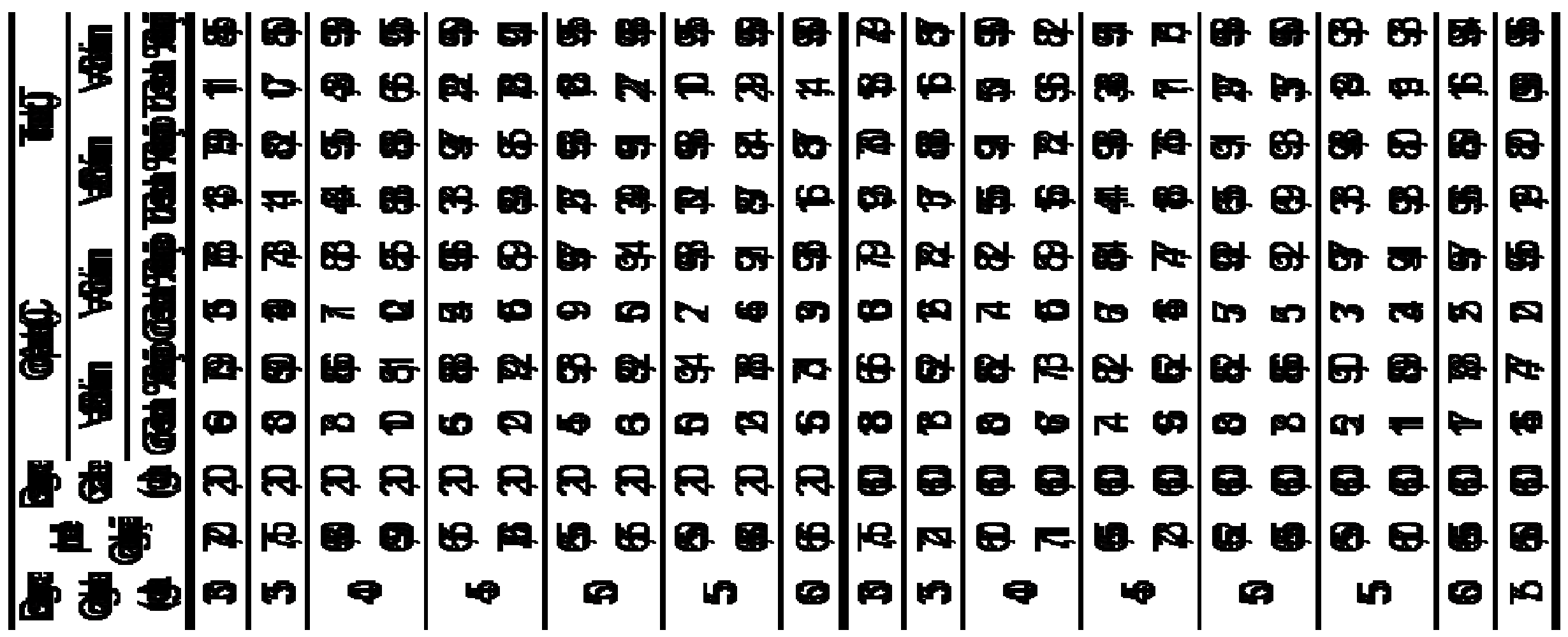




\section{ANEXO C}

Tabela apresentando os resultados de contagem de organismos com a relação de todos os organismos encontrados na cultura, na água do reservatório e para a água de estudo 2. 


\begin{tabular}{|c|c|c|c|c|c|c|}
\hline \multirow[b]{2}{*}{ Taxons } & \multicolumn{2}{|c|}{ Água do Reservatório } & \multicolumn{2}{|c|}{ Água de Estudo } & \multicolumn{2}{|c|}{ Cultura } \\
\hline & $\begin{array}{l}\text { Densidade } \\
\text { org.mL }\end{array}$ & $\begin{array}{c}\text { Abund. } \\
\%\end{array}$ & $\begin{array}{l}\text { Densidade } \\
\text { org.mL }\end{array}$ & $\begin{array}{c}\text { Abund. } \\
\%\end{array}$ & $\begin{array}{l}\text { Densidade } \\
\text { org.mL }\end{array}$ & $\begin{array}{c}\text { Abund } \\
\%\end{array}$ \\
\hline \multicolumn{7}{|l|}{ Cianobactérias } \\
\hline Células de Microcystis & 6.219 & $69.66 \%$ & 41.960 & $99.49 \%$ & 38.030 .633 & $100.00 \%$ \\
\hline Anabaena & 28 & $0.31 \%$ & & & & \\
\hline Aphanocapsa & 193 & $2.17 \%$ & & & & \\
\hline Aphanotece & 55 & $0.62 \%$ & 8 & $0.02 \%$ & & \\
\hline Colonias de Microcystis & 387 & $4.33 \%$ & 57 & $0.14 \%$ & & \\
\hline Gloeocapsa sp & 553 & $6.19 \%$ & 82 & $0.19 \%$ & & \\
\hline lyngbya & 138 & $1.55 \%$ & 20 & $0.05 \%$ & & \\
\hline Não identificada & 55 & $0.62 \%$ & & & & \\
\hline Oscillatoria sp & 83 & $0.93 \%$ & & & & \\
\hline Phormidium & 138 & $1.55 \%$ & 20 & $0.05 \%$ & & \\
\hline Pseudanabaena catenata & 83 & $0.93 \%$ & & & & \\
\hline \multicolumn{7}{|l|}{ Diatomáceas } \\
\hline Aulacoseira granulata & 193 & $2.17 \%$ & 29 & $0.07 \%$ & & \\
\hline Cyclotella menegheniana & 28 & $0.31 \%$ & & & & \\
\hline \multicolumn{7}{|l|}{ Clorofícea } \\
\hline Aktinastrum sp & 83 & $0.93 \%$ & & & & \\
\hline Ankira juday & 111 & $1.24 \%$ & & & & \\
\hline Coelastrum sp & 28 & $0.31 \%$ & & & & \\
\hline Disctiosphaerium sp & 111 & $1.24 \%$ & & & & \\
\hline Planktosphaeria sp & 28 & $0.31 \%$ & & & & \\
\hline Scenedesmus sp & 28 & $0.31 \%$ & & & & \\
\hline Schorederia sp & 28 & $0.31 \%$ & & & & \\
\hline $\begin{array}{l}\text { Selenastrum sp } \\
\text { Criptofícea }\end{array}$ & 28 & $0.31 \%$ & & & & \\
\hline Cryptomonas sp & 83 & $0.93 \%$ & & & & \\
\hline Rhodomonas sp & 138 & $1.55 \%$ & & & & \\
\hline \multicolumn{7}{|l|}{ Euglenofícia } \\
\hline Trachelomonas sp & 28 & $0.31 \%$ & & & & \\
\hline Total & 8.927 & $100 \%$ & 42.177 & $100 \%$ & 38.030 .633 & $00.00 \%$ \\
\hline
\end{tabular}




\section{ANEXO D}

Descrição detalhada da concentração de todos os compostos de trihalometanos analisados para cada situação estudada nesta pesquisa. 


\begin{tabular}{|c|c|c|c|c|c|c|}
\hline & Situação & $\begin{array}{c}\text { Dosagem de } \\
\text { Coagulante } \\
(\mathrm{mg} / \mathrm{L})\end{array}$ & $\begin{array}{c}\text { Dosagem de } \\
\text { Oxidante } \\
\text { (mg/L) }\end{array}$ & $\begin{array}{c}\text { Termpo de } \\
\text { Contato do } \\
\text { Oxidante }\end{array}$ & \multicolumn{2}{|c|}{$\begin{array}{l}\text { Dosagem de } \\
\text { CAP (mg/L) }\end{array}$} \\
\hline & 1 & 45 & 2,1 & $10 \mathrm{~s}$ & \multicolumn{2}{|c|}{-} \\
\hline & 2 & 50 & 2,1 & $10 \mathrm{~s}$ & \multicolumn{2}{|c|}{-} \\
\hline & 3 & 45 & 6 & $10 \mathrm{~s}$ & \multicolumn{2}{|c|}{-} \\
\hline & 4 & 50 & 6 & $10 \mathrm{~s}$ & \multicolumn{2}{|c|}{-} \\
\hline & 5 & 45 & 2,1 & $10 \mathrm{~s}$ & \multicolumn{2}{|c|}{20} \\
\hline & 6 & 50 & 2,1 & $10 \mathrm{~s}$ & \multicolumn{2}{|c|}{20} \\
\hline & 7 & 45 & 6 & $10 \mathrm{~s}$ & \multicolumn{2}{|c|}{20} \\
\hline & 8 & 50 & 6 & $10 \mathrm{~s}$ & \multicolumn{2}{|c|}{20} \\
\hline & 9 & 50 & 2,1 & $90 \mathrm{~min}$ & \multicolumn{2}{|c|}{-} \\
\hline & 10 & 50 & 2,1 & $90 \mathrm{~min}$ & \multicolumn{2}{|c|}{-} \\
\hline & 11 & 50 & 6 & $90 \mathrm{~min}$ & \multicolumn{2}{|c|}{20} \\
\hline & 12 & 50 & 6 & $90 \min$ & \multicolumn{2}{|c|}{20} \\
\hline \multirow{2}{*}{ Situação } & \multicolumn{6}{|c|}{ Trihalometanos - THM $(\mu \mathrm{g} / \mathrm{L})$} \\
\hline & \multicolumn{2}{|c|}{ Clorofórmio } & oromodiclorometano & \multicolumn{2}{|c|}{ dibromoclorometano } & bromofórmio \\
\hline 1 & \multicolumn{2}{|r|}{$<2,0$} & $<2,0$ & \multicolumn{2}{|c|}{ N.D.** } & $<2,0$ \\
\hline 2 & \multicolumn{2}{|r|}{$\mathrm{Nd}^{*}$} & $<2,0$ & \multicolumn{2}{|c|}{$<2,0$} & $<2,0$ \\
\hline 3 & \multicolumn{2}{|c|}{8,54} & N.D. ${ }^{* *}$ & \multicolumn{2}{|c|}{$<2,0$} & $<2,0$ \\
\hline 4 & \multicolumn{2}{|c|}{11,23} & N.D. ** & \multicolumn{2}{|c|}{ N.D. ** } & N.D. ** \\
\hline 5 & \multicolumn{2}{|c|}{2,56} & $<2,0$ & \multicolumn{2}{|c|}{ N.D. ${ }^{* *}$} & $<2,0$ \\
\hline 6 & \multicolumn{2}{|r|}{9,43} & $<2,0$ & \multicolumn{2}{|c|}{ N.D. ** } & N.D. ** \\
\hline 7 & \multicolumn{2}{|r|}{6,11} & $<2,0$ & \multicolumn{2}{|c|}{ N.D.** } & N.D. ** \\
\hline 8 & \multicolumn{2}{|r|}{5,88} & $<2,0$ & N.D.' & & N.D. ** \\
\hline 9 & & $<2,0$ & $<2,0$ & N.D.' & & $<2,0$ \\
\hline 10 & & 6,44 & $<2,0$ & $<2$ & & $<2,0$ \\
\hline 11 & & 3,47 & $<2,0$ & N.D.' & & $<2,0$ \\
\hline 12 & & 1,71 & $<2,0$ & N.D.' & & $<2,0$ \\
\hline
\end{tabular}

